\title{
INDEX TO AUTHORS
}

Arccroft, W. M. Observations on the hremoglobin level of cows and sheep, 1941, 31, 320

Arlen, L. A., Harrison, J., Watson, S. J. and Ferguson, W. S. A study of the chemical and bacteriological changes occurring in grass silage, 1937, 27, 271 .

Alles, L. A., Watson, S. J. and Ferguson, $W . S$. The effect of the addition of various materials and bacterial cultures to grass silage at the time of making on the subsequent bacterial and chemical changes, $1937,27,294$

ALPER, P. An accurate wet-combustion method for the determination of carbon in soils, $1938,28,187$

ALPER, P. Note on an accurate wet.com. bustion method for the determination of carbon in soils, 1942, 32, 389

Altson, R. A. Studies on Azotobacter in Malayan soils, 1936, 26, 268

'Alumsvs.' A comparison of the effect of rainfall on spring- and autuma-dressed wheat at Rothamsted Experimental Station, Harpenden, 1932, 22, 101

ANderson, J. Ovulation in the ewe, 1936, 26, 64

ANDERSON, J. Artificial insemination of sheep. I. Preliminary investigation and its application to sheep in Kenya, 1937, 27,143

ANDERson, J. Further investigations on artificial insemination of cattle, 1941, 31 , 348

ANDERSON, J. Further investigations on artificial insemination of sheep, 1941, 31, 354

ANDerson, J. The hydrogen-ion concentration of the semen of the bull, 1942, 32, 298

ANDFrson, J. The periodicity and duration of cstrus in zebu and grade cattle, 1944, 34,57

ANDERSON, $J$. The change in the $p \mathrm{H}$ of the semen of the bull after incubation, 1944 34,69

ANDERson, J. Seasonal variation in the reproductive capacity of the bull, 1945 , 35, 184

ANdersson, G., see Mather, $K$.

ARmTaan, E. R., see Ferguson, W. S.

Armstrong, J. M. and White, W. J. Factors influencing seed-setting in alfalfa, $1935,25,161$

Ashton, F. L. Selenium as a catalyst in the Kjeldahl method as applied to soil and grass analysis, 1936, 26, 239

JAs I ii
Ashwortr, M. R. F. Changes occurring in the organic matter during the decomposition of compost heaps, 1942, 32, 360 AstwoRTh, M. R. F. The fractionation of the organic matter, including nitrogen, of certain soils and its relation to their quality, 1942, 32, 349

Auchinache, D. W. and Fraser, A. H. H. The effect of lime and cod-liver oil on sheep fed on a calcium deficient ration, $1932,22,560$

Balcerek, W, see Russell, E. W.

BarNaRd, M. M. An examination of the sampling observations on wheat of the crop-weather scheme, 1936, 26, 456

Barnes, T. W., see MaNN, H. H.

BarteI, L. H., see Remers, J. H. W. TH.

BARTLETT, M. S. An examination of the value covariance in dairy cow nutrition experiments, 1935, 25, 238

BarTLETT, M. S. A note on the analysis of covariance, $1936,26,488$

BARTLETT, M. S. The approximate recovery of information from replicated field experiments with large blocks, 1938, 28, 418

BarTlett, M. S. and GreenimL, A. W. The relative importance of plot variation and of field and laboratory sampling errors in small plot pasture productivity experiments, 1936, 26, 258

BASU, J. K. Studies on soil reaction. VII. An electro-dialysis apparatus for the determination of replaceable bases in soils, 1931, 21, 484

Basu, J. K., see also Crowther, E. M.

BATES, G. H. A study of the factors influencing size of potato tubers, 1935, 25, 297

BAUER, A. B., see BELL, G. D. H.

BeATER, B. E. Improved technique in grading of coarse and fine sands during mechanical analysis of soils, 1937, 27, 123

BELL, G. D. H. Preliminary experiments on vernalization, $1935,25,245$

BeLL, G. D. H. Experiments on vernaliza. tion, 1936, 26, 155

BeLL, G. D. H. The effect of low.tempera. ture grain pre-treatment on the development, yield and grain of some varieties of wheat and barley, 1937, 27, 377

BELL, G. D. H. A study on the date of ear emergence in barley, 1939, 29, 175

BELL, G. D. H. The breeding of two-row winter-hardy barley, 1944, 34, 223 
Bell, G. D. H. and BAUER, A. B. Experiments on growing sugar beet under continuous illumination. I-II, 1942, 32, 112

BeLL, G. D. H. and BAUER, A. B. Experiments on growing sugar beet under continuous illumination. III. The production of a seed crop in the field and the resolu. tion of a heterogeneous population, 1943, 33, 85

Beil, G. D. H. and Carson, G. P. The inheritance of rachilla length in barley, $1941,31,246$

Belu, G. D. H., Girson, M. R. and Weston, W. A. R. D. Experiments on cutting potato tubers, $1942,32,255$

BEST, R. J. A comparison of methods for determining the hydrogen-ion concentration of soils, 1931, 21, 337

Bhattacharya, P., see Hammond, J. jun. Birch, H. F., see IN Nes, R. F.

BLackmaN, G. E. The influence of temperature and available nitrogen supply on the growth of pasture in the spring, 1936, 26, 620

Blackman, G. E. and Templeman, W. G. The eradication of weeds in cereal crops by sulphuric acid and other compounds, $1936,26,368$

Blackman, G. E. and Templeman, W. G. The nature of the competition between cereal crops and annual weeds, 1938, 28, 247

Blarr, G. W. S. Compressibility curves as a quantitative measure of soil tilth, 1937, 27, 541

Blair, G. W. S. and Cashen, G. H. Compressibility curves as a quantitative measure of soil tilth. II, 1938, 28, 367

BlaIR, G. W. S. and Yates, F. The effect of climatic variations on the plasticity of soil, 1932, 22, 639

BlaIr, G. W. S., see also Keen, B. A.

Blaxter, K. L. Experiments on the use of home-grown foods for milk production. I. The effect of war-time changes in the food supply on the nutrient intake and milk-production of dairy cows, 1944, 34, 22

Blaxter, K. L. Experiments on the use of home-grown foods for milk production. II. The effect of feeding concentrated and bulky foods prior to calving on sub. sequent milk production, 1944, 34, 27

BLAXTER, K. L. Experiments on the use of home-grown foods for milk production. III. The effect of over- and underfeeding during mid-lactation, 1944, 34, 213

Blaxter, K. L. and French, T. H. Experiments on the use of home-grown foods for milk production. IV. Methods of feeding bulky foods, 1944, 34, 217
Blyth, J. S. S., see Greeywood, A. W.

Bolton, W. The riboflavin requirement of the White Wyandotte chick, 1944, 34, 198

Bolton, W, and Hase, W. Dried potato products for egg production: statistical analysis of a laying experiment, 1945, 35, 158

Bolton, W., see also Common, R. H.

BONDI, A. H. and MEYER, H. On the chemical nature and digestibility of roughage carbohydrates, $1943,33,123$

Bond, A. H. and MeYER, H. Digestibility trials with poultry. The digestibility of dura, carobs and hide-fleshings, 1944, 34, 118

Booer, J. R., see Brett, C. C. and Weston, W. A. R. D.

BothaM, G. H., see Davies, W. M.

Bottomley, A. C., Folley, S. J. and Watson, H. M. S. Experiments on the use of chorionic gonadotrophin (preg. nancy urine extract) for the treatment of sterility in dairy cattle, 1940, 30, 235

BOYD, D. A., see Y

BRADY, J. Some factors influencing lodging in cereals, 1934, 24, 209

BraUde, R. Some observations on the need for copper in the diet of fattening pigs, $1945,35,163$

BRAUDE, R. and FOoT, A. S. War-time rations for pigs. Report of experiments with mangolds and biscuit waste, fodder yeast, urea and dried skim milk, 1942, 32, 70

Bratde, R. and Foot, A. S. Pig-feeding experiment using dried Clostridium residue, $1942,32,324$

Brenchley, W. E. The action on the growth of crops of small percentages of certain metallic compounds when applied with ordinary artificial fertilizers, 1932 , 22, 704

Brenchley, W. E., see also Crowther, W. E.

Brett, C. C. and Weston, W. A. R. D. Seed disinfection. IV. Loss of vitality during storage of grain treated with organo-mercury seed disinfectants, 1941, 31, 500

Brett, C. C., Weston, W. A. R. D. and BOokr, J. R. Seed disinfection. III. Experiments on the germination of peas. Seed protection by the use of disin. fectant dusts containing mercury, 1937, 27,53

Brovwer, E. and DiJkstra, N. D. On alimentary acetonuria and ketonuria in dairy cattle induced by feeding grass silage of the butyric acid type, 1938, 28, 695

Brown, R. Nitrogen fixation by the endo- phyte of Lolium, 1933, 23, 527 
Bryan, H. The maintenance of healthy stocks of potatoes in England, 1932, 22, 358

Burton, J. C., see Wilson, P. W.

Calder, R. A., see Hadfield, J. W.

CaLdWell, J. and Richardson, H. L. The growth of clover in the presence of ammonium sulphate, 1936, 26, 263.

Callow, E. H. The food value of beef from steers and heifers, and its relation to dressing-out percentage, 1944, 34, 177

CALLOW, E. H., see also WoodmaN, H. E.

Campbell, J. T., see Ward, A. H.

Campbent, K. W. D. A new view of the effect of temperature on milk production in dairy cows, 1931, 21, 167

Carman, P. C. Permeability of saturated sands, soils and clays, 1939,29,262

Carson, G. P., see Bell, G. D. H.

Cashen, G. H. Measurements of the electrical capacity and conductivity of soil blocks, 1932, 22, 145

CASHEN, G. H., see also BLATR, G. W. S. and KEEN, B. A

Chana, M. C. Sperm production of a pony stallion and the treatment of spermatozoa in vitro with special reference to artificial insemination, 1943, 33, 67

Chano, M. C. The sperm production of adult rams in relation to frequency of semen collection, $1945,35,243$

Cher, H. K. The limited numbers of nodules produced on legumes by different strains of Rhizobium, 1941, 31, 479

ChILd, $E$. C. The transport of water through heavy clay soils. I, 1936, 26, 114

CHnLds, E. C. The transport of water through heavy clay soils. III, 1936, 26, 527

Chmos, E. C. Studies in mole-draining. Interim report on an experimental drainage field, 1943, 33, 136

Critcds, E. C., see also Nichorsun, H. H.

Chippindale, H. G. and Mrrton, W. E. J. Note on the occurrence of buried seeds in the soil, 1932, 22, 451

Christridis, B. G. The importance of the shape of plot in field experimentation, 1931, 21, 14

Crristrdis, B. G. Intervarietal competition in yield trials with cotton, $1935,25,231$

Christrois, B. G. Cotton-seed treatment with sulphuric acid, 1936, 26, 648

Clapham, A. R. Studies in sampling technique: cereal experiments. I. Field technique, 1931, 21, 366

Clapham, A. R. Studies in sampling technique: cereal experiments. III. Results and discussion, 1931, 21, 376

Cochran, W. G. A note on the influence of rainfall on the yield of cereals in relation to manurial treatment, $1935,25,510$
Cochran, W. G. The estimation of the yields of cereal experiments by sampling for the ratio of grain to total produce, 1940, 30, 262

Cochran, W. G., see also Crowther, F. and YATES, F.

Common, R. H. Mineral balance studies on poultry, 1932, 22, 576

Commos, R. H. Observations on the mineral metabolism of pullets, 1933, 23, 555

Common, R. H. Observations on the mineral metabolism of pullets. II, 1936, 26, 85

Common, R. H. Serum phosphatase in the domestic fowl, 1936, 26, 492

Common, R. H. Observations on the mineral metabolism of pullets. III, 1938, 28, 347

Common, R. H. Observations on the mineral metabolism of pullets. IV, 1940 , 30, 113

Common, R. H. Observations on the mineral metabolism of pullets. $V$. Acid-base equilibrium and reproductive activity, 1941, 31, 281

Common, $\mathbf{R}$. H. The carbonic anhydrase activity of the hen's oviduct, 1941, 31, 412

Common, R. H. Observations on the mineral metabolism of pullets. VII. The calcium requirement of the laying bird, $1943,33,213$

Common, R. H. The composition and digestibility of Northern Irish ryegrass seed and ryegrass seed cleanings, 1945, 35, 56

Common, R. H. and Bolton, W. Electrode potentials in laboratory silage, 1942,32 , 338

Common, R. H. and Haxe, R. W. Observations on the mineral metabolism of pullets. VI. The mobilization of body calcium for shell formation, 1941, 31, 415

Common, R. H., see also RUTLedge, W. A.

Comrie, A., see SmTrh, A. M.

Copeman, P. R. v. D. R. and Dillman, F. J. Changes in the composition of guano during storage, $1937,27,178$

Costa, J. V. B. DA. A critical survey of investigations on the 'wilting coefficient' of soils, 1938, 28, 630

CosTa, J. V. B. DA. The indirect determination of the 'wilting coefficient' by the freezing-point method, and the influence of the salts upon the $p \mathrm{~F}$ at that critical moisture content, 1938, 28, 654

Costa, J. V. B. DA and Arves, J. A. The determination of the moisture equivalent by the silt-suction method and the shifting of the $p \mathrm{~F}$ curve of stored soil samples, 1942, 32, 294

Costa, J. V. B. DA, see also Schopteld, R. K. 
CodTTs, J. R. H. 'Single value' soil constants: a study of the significance of certain soil constants. VI. On the changes produced in a soil by exposure to high temperatures, 1932, 22, 200

Coutrs, J. R. H. 'Single value' soil properties: a study of the significance of certain soil constants. VII. The moisture equivalent and some related quantities, 1932, 22, 203

Coutrs, J. R. H. 'Single value' soil properties: a study of the significance of certain soil constants. VIII. Relationships between the sticky point and the nature of the exchangeable ions in the soil, 1935, 25, 523

Cowis, G. A. Study of the effects of fertilizers and rainfall on yields of crops grown in rotation, $1945,35,197$

Cowre, G. A., see also KNowles, F.

Crowther, E. M. and BaSU, J. K. Studies on soil reaction. VIII. The influence of fertilizers and lime on the replaceable bases of a light acid soil after fifty years of continuous cropping with barley and wheat. (An examination of the stackyard and field plots, Woburn Experimental Station), 1931, 21, 689

Crowther, E. M. and Brenchuey, W. E. The fertilizing value and nitrifiability of humic materials prepared from coal, $1934,24,156$

Crowther, E. M. and Mrrohandani, T. J. Winter leaching and the manurial value of green manures and crop residues for winter wheat, 1931, 21, 493

Crowther, E. M. and Richardson, H. L, Studies on calcium cyanamide. I. The decomposition of calcium cyanamide in the soil and its effects on germination, nitrification and soil reaction, 1932, 22,300

CROWXHER, E. M., see also RICHaRdson, H. L.

Crowther, F. and Cochran, W. G. Rotation experiments with cotton in the Sudan Gezira, 1942, 32, 390

Crowthre, F., see also Gregory, F. G.

Crutckshank, D. B., see Marshall, W.

Crurcrshank, E. M. A note on the effect of different cereals in the fattening ration on the composition of the body fat of the fowl, 1937, 27, 309

Culpin, C. Studies on the relation between cultivation implements, soil structure and the crop. I. Some preliminary observa. tions on the measurement of soil structure, with a description of an instrument for the measurement of soil resistance, 1936, 26,22

CULPIN, C. Studies on the relation between cultivation implements, soil structure and the crop. II. The effects of the Fowler 'Gyrotiller' on the soil. 1936, 26, 45
CurpIs, C. Studies on the relation between cultivation implements, soil structure and the crop. III. Rolls: an account of methods employed in a study of their actions on the soil, 1937, 27, 432

Cunningham, A., see Guathi, H.

DAJ, J. A. The decomposition of green manures in soil, 1934, 24, 15

DaveY, D. G. Notes on the osmotic pressure of the contents of the stomach compartments of the sheep, 1936, 26, 328

Davey, V. McM. The method of sampling swede bulbs by cores, $1932,22,767$

Davidson, A. L. C. and Schomield, R. K. Measurement of the suction of soil water by Portland stone absorbers calibrated by a new method for determining vapour pressures near to saturation, 1942,32 , 413

Davies, W. M., Botham, G. H. and Thompson, W. B. Grass silage, A com. parison of the changes involved in the ordinary, molasses and A.I.V. processes, $1937,27,151$

$D_{\triangle Y}, F . T$. Ovulation and the descent of the ovum in the fallopian tube of the mare after treatment with gonadotrophic hormones, 1939, 29, 459

$D_{A Y}, F$. T. The oestrous cycle of the mare following removal of the foetus at various stages of pregnancy, $1939,29,470$

$D_{A Y}, F$. T. Clinical and experimental observations on reproduction in the mare, $1940,30,244$

$D_{A Y}, F . T$. Survival of spermatozon in the genital tract of the mare, $1942,32,108$

DAY, F. T. and Hammond, J. jun. Lactation in heifers induced by oestrogen implants, 1945, 35, 150

Dean, L. A. An attempted fractionation of the soil phosphorus, 1938, 28, 234

Derghtos, $T$. The determination of the surface area of swine and other animals, $1932,22,418$

Derghton, $T$. A study of the fasting metabolism of various breeds of hog. I. Introductory: age, weight and length data, etc., 1934, 24, 326

Deighton, $T$. A study of the fasting metabolism of various breeds of pig. II. Body temperature measurements, 1935, 25,180

Deighton, T. A study of the fasting metabolism of various breeds of hog. III. Metabolism and surface area measurements, 1937, 27, 317

Deianton, T. A study of the metabolism of fowls. I. A calorimeter for the direct determination of the metabolism of fowls, $1939,29,431$ 
Deighton, T. and Hutchunson, J. C. D. Studies on the metabolism of fowls. II. The effect of activity on metabolism, $1940,30,141$

Detahton, T. and Hutohinson, J. C. D. Studies on the metabolism of fowls. III. The determination of the comparative nett energy of Sussex ground oats and white maize meal for fattening cockerels, $1940,30,463$

De La Mare, P. B. D., see Shortand, F. B.

DiJkstra, N. D., see Brouwrr, E.

Drmlman, F. J., see Copeman, P. R. v. D. R.

Donald, H. P. and El Itriby, A. A. Herd size and its, genetical significance in pedigree cattle breeding, 1945, 35, 84

Donatd, H. P., see also SmITH, A. D. B.

DOYNE, H. C. Studies in tropical soils. In crease of acidity with depth, 1935, 25, 192

Dorne, H. C. and Watson, W. A. Soil formation in Southern Nigeria. (The 'Ilepa' profile), 1933, 23, 208

DUCKWORTH, J., GODDEN, W. and THOMSON, $W$. The relation between rates of growth and rickets in sheep on diets deficient in vitamin D, 1943, 33, 190

DUDLEY, F. J. Results of crossing the Rhode Island Red and White Leghorn breeds of poultry, 1944, 34, 76

DUDLEY, F. J. and WILSON, W. K. Carcass investigations with rabbits. Some observations on the weights of rabbits at time of killing, 1943, 33, 129

DudLey, F. J., see also Temperton, $H$.

DUNLOP, G. Methods of experimentation in animal nutrition, $1933,23,580$

Dunlor, G. Reply to note by E. J. Sheehy on methods of experimentation in animal nutrition, 1934, 24, 335

Dunlop, G. Paralysis and avitaminosis in swine, 1934, 24, 435

Dundor, G. The calcium, phosphorus and vitamin D requirements of swine, 1935 , 25,22

DUNLOP, G. The control of variation in gain in animal nutrition experiments, $1935,25,151$

DUNLOP, $G$. The vitamin A requirement of swine, 1935, 25, 217

Donsop, G. The effect of the growthpromoting, appetite-stimulating or 'phy sin' factor on the live-weight increase of swine, 1935, 25, 445

DரThre, D. W. Studies in tropical soils. IV. Organic transformations in soils, composts and peat, 1937, 27, 162

Do Torr, M. M. S. and Page, H. J. Studies on the nitrogen cycles in the soil. IV. Natural and artificial humic acids, 1932, 22, 115

Epen, A. Studies on the excretion of copper in the rabbit, $1941,31,145$
EDEN, A. Further observations on the blood copper of Northumbrian sheep, $1941,31,186$

Eden, A., see also Woodman, H. E.

EDen, T. Studies in the yield of tea. I. The experimental errors of field experiments with tea, 1931, 21, 547

EDEN, T. Studies in the yield of tea. II The seasonal and sampling variation in yield and mineral composition of the tea leaf, 1932, 22, 386

EDEN, T. and YATES, F. On the validity of - Fisher's $z$ test when applied to an actual example of non-normal data, 1933, 23, 6

EDWARDS, J. The progeny test as a method of evaluating the dairy sire, 1932, 22, 811

EdWards, J., Walton, A. and SImbenga, J. On the exchange of bull semen between England and Holland, 1938, 28, 503

EgGLEToN, W. G. E. Studies on the microbiology of grassland soil. I. General chemical and microbiological features, 1934, 24, 416

ELDER, S. and MCCALL, R. J. S. A study in the mineral composition of the soils of South Ayrshire, 1936, 26, 1

EL Itriby, A. A., see Donald, H. P.

Elutotr, F. J. and Thomas, B. On the yields and composition of meadow hay from certain of the Palace Leas plots at Cockle Park, 1934, 24, 377

Euliotw, F. J., see also Thomas, B.

ElPhoK, B. L. and MoMahon, P. R. Note on the estimation of dry matter in mangels, 1935, 25, 1

Enaledow, F. L. and PAL, B. P. Investigations on yield in cereals. VIII. Hybrid vigour in wheat, 1934, 24, 390

EvaNs, R. E. Studies of the sulphur of pasture grass. I. The cystine content of pasture grass, 1931, 21, 806

Evans, R. E., see also Woodman, H. E.

Ferauson, W. S. Investigations into the intensive system of grassland management by the Agricultural Research Staff of Imperial Chemical Industries, Limited. III. The seasonal variation in the mineral content of pasture with particular reference to drought, 1931, 21, 233

Fergoson, W. S. Investigations into the intensive system of grassland management by the Agricultural Research Staff of Imperial Chemical Industries, Iimited. $X$. A further study of the mineral content of intensively treated pasture, $1932,22,251$

Ferauson, W. S. The teart pastures of Somerset. IV. The effect of continuous administration of copper sulphate to dairy cows, 1943, 33, 116

Feravson, W. S. The digestibility of straw pulp, 1943, 33, 174 
Ferguson, W. S. and Armtage, E. R. The chemical composition of bracken (Pteridium aquilinum), 1944, 34, 165

Ferauson, W. S., Lewts, A. H. and Watson, S. J. The teart pastures of Somerset. I. The cause and cure of teartness, $1943,33,44$

Ferguson, W. S. and Neave, O. Nutritive value of ammoniated sugar-beet pulp, $1943,33,95$

Ferguson, W. S. and Neave, O. Bracken ensilage, 1944, 34, 172

Ferguson, W. S. and Watson, S. J. The composition and nutritive values of seeds hays, $1944,34,88$

Ferouson, W. S., see also ALLEN, L. A. and Watson, S. J.

Fieldina, W. L., see Macdonald, D.

Fisher, E. A. and Jones, C. R. The influence of manurial treatment on the baking quality of English wheat. I. A quality study of the Rothamsted Broadbalk wheats, 1931, 21, 574

Follett-Smith, R. R., see Hardy, F.

Foldey, S. J., see Botromate, A. C.

FOOT, A. S., HENRY, K. M., KON, S. K. and Mackintosh, J. Pig-feeding experiments with cod-liver oil, $1939,29,142$

Foot, A. S., see also BraUde, R.

Foreman, F. W. Observations on the proteins of pasturage. Phosphorus and protoplasm, 1938, 28, 135

FORSTER, H. C. and VASEY, A. J. Investigations on yield in cereals. Victoria. I. Census studies 1927-9, 1931, 21, 391

Frankel, O. H. The differentiation of grain samples of closely related varieties of wheat by means of a simple mechanical test for grain quality, 1935, 25, 461

Franker, O. H. Analytical yield investigations on New Zealand wheat. II. Five years' analytical variety trials, 1935, 25, 466

Frankel, O. H. Analytical yield investigations on New Zealand wheat. IV. Blending varieties of wheat, 1939, 29, 249

FRA NKEx, O. H. A critical survey of breeding wheat for baking quality, 1940, 30,98

Fraser, A. H. H. and Roberts, J. A. F. Variation in the protein intake of sheep in relation to wool growth, 1933, 23, 97

FraSer, A. H. H., see also Auchinachie, D. W.

French, M. H. The comparative digestive powers of zebu and high-grade European cattle, $1940,30,503$

French, M. H., see also Woodman, H. E.

Furneaux, B. S. and Glasscock, H. H. Soils in relation to marsh spot of pea seed, $1936,26,59$
Gallagher, P. H. and Walsh, T. The susceptibility of cereal varieties to manganese deficiency, 1943, 33, 197

GaLPIN, N. The pre-natal development of the coat of the New Zealand Romney lamb, 1935, 25, 344

Galpin, N., see also Greenwood, A. W.

G $\triangle$ RDNER, H. W. The response of permanent grassland to nitrogen and the efficiency of its recovery, 1939, 29, 364

GaRDNER, H. W., HUNTER-Smith, J. and Wnimams, H. R. Further observations on the nitrogenous manuring of grassland, $1931,21,780$

Garner, F. H., Grantham, J. and Sanders, $H$. G. The value of covariance in analysing field experimental data, 1934, 24, 250

GarNer, F. H., GranthaM, J. and SaNders, H. G. An electric oven for drying samples from field plots, 1935, 25, 315

GarNer, F. H. and SANDERS, H. G. Investigations in crop husbandry. I. The effects of seed treatments on the germination and yield of sugar beet, $1932,22,551$

Garner, F. H. and SANDERs, H. G. Investigations in crop husbandry. II. On the age of seed beans, 1935, 25, 361

GaRner, F. H. and Sanders, H. G. The effects of different methods of castration and docking on the growth of lambs, $1936,26,296$

Garner, F. H. and Sanders, H. G. Investigations in crop husbandry. III. Effect of time of application of sulphate of ammonia to wheat, 1936, 26, 316

GarNer, F. H. and SANDERS, H. G. Investigations in crop husbandry. IV. The preparation of the seed bed for wheat after potatoes, 1936, 26, 415

Garner, F. H. and SAnders, H. G. On the spring cultivation of autumn-sown wheat, $1937,27,447$

Garner, F. H. and SANDers, H. G. The water consumption of suckling sows, $1937,27,638$

Garner, F. H. and SAnders, H. G. The effect of the 'gyrotiller' on crop yield, $1938,28,401$

Garner, F. H. and Sanders, H. G. A study of the effect of feeding oils to dairy cows and of the value of the Latin square lay-out in animal experimentation, 1938, 28, 541

GaRNer, F. H. and SANDERs, H. G. Experiments on the spacing of sugar beet. I. Results based on plot yields, 1939, 29, 48

Garner, F. H. and Sanders, H. G. Experiments on the spacing of sugar beet. II. Results based on weights of individual plants, $1939,29,58$ 
Garner, F. H. and SANDERS, H. G. Fouryear leys: the inclusion of red clover: first-year management, 1939, 29, 164

GARNER, F. H. and SANDERS, H. G. Studies with lucerne (Medicago sativa) row distances and 'smother' orops, 1940 , 30,182

GILson, M. R., see BeLL, G. D. H.

GLaSSCOCK, H. H. and WaIN, R. L. Distribution of manganese in the pea seed in relation to marsh spot, $1940,30,132$

Grasscock, H. H., see also Furnea UX, B.S.

Glathe, H. and Conningham, A. The obligate anaerobic micro-flora of farm. yard manure, 1933, 23, 541

GODDEN, W., see DUCKWORTH, J.

GoOCH, M. An analysis of the time change in milk production in individual lacta. tions, $1935,25,71$

Gowes, J. W. Conformation of the cow as related to milk secretion, Jersey Registry of Merit, 1933, 23, 485

Gowen, J. W. The conformation of the parents as related to the milk secretion of the daughters, Jersey Registry of Merit, $1933,23,514$

GranthaM, J., see GarNer, F. H.

GreEN, W. H. The representation of soil analyses by the device of double plotting, $1932,22,548$

Greene, H. and Peto, R. H. K. The effect of irrigation on soil salts at the Gezira Research Farm, Wad Medani, Sudan, 1934, 24, 42

Greene, H. and Snow, 0.'W. Soil improvement in the Sudan Gezira, 1939 29,1

Greenhuld, A. W. and Page, H. J. Investigations into the intensive system of grassland management by the Agricultural Research Staff of Imperial Chemical Industries, Limited. II. The mineral content of intensively treated pasture and a relationship between the nitrogen and phosphorus contents, 1931 , 21, 220

GreenhrLl, A. W. and PAGE, H. J. A note on the employment of a mixture of sand and calcium bentonite as the growth medium in pot culture and the establish. ment therein of a sward of perennial rye grass, 1933, 23, 329

GREENHILL, A. W., see also BarTLETT, M. S.

GreENwood, A. W., BLYTh, J. S. S. and GaupIN, N. A study of fecundity in the domestic fowl: the behaviour of persistency in individual hens, 1940,30 , 202

Gregory, F. G., Crowther, F. and LAMBERT, A. R. The inter-relation of factors controlling the production of cotton under irrigation in the Sudan, $1932,22,617$
Groves, R. C. The chemical analysis of clays, with special reference to clay fractions of soils, 1933, 23, 519

GDPTA, R. S., see RussELL, E. W.

Hadfield, J. W. and Calder, R. A. A genetic analysis of the seed characters wrinkled, dimpled and smooth in Pisum, $1935,25,264$

HaLE, R. W. Experimental errors in chicken-rearing experiments, 1931, 21, 716

HaLe, W., see also BoLton, W. and Common, R. H.

HaLNaN, E. T. Digestibility trials with poultry. VII. The digestibility of wheat offals, with a note on the apparent discrepancy between the digestibility coefficients and nutritive values of these products, 1937, 27, 126

HalNan, E. T. Digestibility trials with poultry. VIII. The digestibility of dried molassed sugar-beet_pulp, 1937, 27, 137

HaLnan, E. T. On the influence of protein on the fattening of fowls, 1938, 28, 341

HaLNAN, E. T. Some observations on the normal variations in composition of light Sussex cockerels, 1938, 28, 379

HaLNAN, E. T. Observations on the value of whale-meat as a constituent of chick diets, with a note on the influence of added protein on the efficiency of utilization of the gross energy of a ration, 1942, 32, 179

HALNAN, E. T. Digestiblity trials with poultry. IX. The digestibility and metabolizable energy of sunflower seeds, $1943,33,113$

HalnaN, E. T. Digestibility trials with poultry. $X$. The effect of war-time changes in milling practice on the composition and nutritive value of fine and coarse wheat bran, 1944, 34, 133

HalnaN, E. T. Digestibility trials with poultry. XI. The digestibility and metabolizable energy of raw and cooked potatoes, potato flakes, dried potato slices and dried potato shreds, 1944, 34, 139

Hamiton, S. N., see Shutt, F. T.

Hammond, J. jun. On the breeding season in the sheep, 1944, 34, 97

Hammond, J. jun. and Brattacharya, P. Control of ovulation in the cow, 1944, 34, 1

HAMmOND, J. jun., HAMMOND, J. and PARKES, A. S. Hormonal augmentation of fertility in sheep. I. Induction of ovulation, superovulation and heat in sheep, 1942, 32, 308

Hammond, J. jun., see also DAx, F. T. 
Hammond, J. and Murray, S. N. Grading meat: the prices given for carcases of different weights and qualities, 1934, 24, 233

Hammond, J. and Murray, G. N. The body proportions of different breeds of bacon pigs, 1937, 27, 394

Hammond, J., see also Hammond, J. jun. and WISHART, $\mathrm{J}$.

Hanley, F., see Weston, W. A. R. D.

FARDY, F. Studies in tropical soils. I. Identification and approximate estimation of sesquioxide components by adsorption of alizarin, 1931, 21, 150

Hardy, F. Studies in tropical soils. III. The shrinkage behaviour of lateritic and kaolinitic soils, 1934, 24, 59

HARDY, F. and FolletT-Smith, R. R. Studies in tropical soils. II. Some characteristics of igneous rock soil profiles in British Guiana, South America, 1931, 21, 739

HARDY, F., MCDonald, J. A. and Rodriguez, G. Leaf analysis as a means of diagnosing nutrient requirements of tropical orchard crops, 1935, 25, 610

Harris, L. J. Note on the vitamin $B_{1}$ potency of wheat as influenced by soil treatment, 1934, 24, 410

Harrison, J., see ALlen, L. A.

HART, R. Soil studies in relation to geology in an area in north-east Scotland. I. The mineralogy of the soil parent materials, 1941, 31, 438

HART, R. Soil studies in relation to geology in an area in north-east Scotland. II. The soils and their development, 1942, 32, 373

Hartley, H. O., see Hunter, H.

Hatoher, E. S. J. and Purvis, O. N. On the behaviour in the field of small grain obtained by premature harvesting, 1945 , 35, 177

von Hausen, S., see Virtanen, A. I.

Havas, L. Some effects of radioactive mud upon germination of seeds and growth of seedlings, 1935, 25, 198

HeATH, O. V. S. A study in soil cultivation. The effects of varying soil consolidation on growth and development of raingrown cotton, 1937, 27, 511

Heintze, S. G. The use of the glass electrode in soil reaction and oxidation-reduction potential measurements, 1934, 24, 28

HeINTzE, S. G. Readily soluble manganese of soils and marsh spot of peas, 1938, 28, 175

HendRrcks, W. A. The use of 'differential regression' in analysis of variance, 1935, 25,258

HeNDRIoks, W. A. A note on the method of 'differential regression" in analysis of variance, 1937, 27, 188
Hendricks, W. A. and Titus, H. W. A note on Wood and Capstick's method of calculating the maintenance requirements of the adult sheep, 1931, 21, 726

HENDRY, F. W. F., see KNowles, F.

Henry, K. M., see Foot, A. S.

HEY, G. B. and KEMSLEY, W. F. F. Experiments on the spacing of sugar beet. III. Further statistical considerations, 1939, 29, 69

HrNe, H. J., see RUSSELL, E. W.

HrRzEL, R. Note on the effect of 'condition' on the colour of body fat in rabbits, $1935,25,541$

Honsos, R. P. Calcium and hydrogen-ion concentration and the interfacial tension of pyrethrum extracts, 1931, 21, 101

Hobson, R. P. and PAGE, H. J. Studies on the carbon and nitrogen cycles in the soil. VI. The extraction of the organic nitrogen of the soil with alkali, 1932, 22, 297

Hobson, R. P.-and Page, H. J. Studies on the carbon and nitrogen cycles in the soil. VII. The nature of the organic nitrogen compounds of the soil: 'humic' nitrogen, 1932, 22, 497

HoBson, R. P. and PAGE, H. J. Studies on the carbon and nitrogen cycles in the soil. VIII. The nature of the organic nitrogen compounds of the soil: "nonhumic' nitrogen, 1932, 22, 516

Horton, E. A., see Watson, S. J.

Hosking, J. S. The influence of hydrogenion concentration on the decomposition of soil organic matter by hydrogen peroxide, 1932, 22, 92

HoskING, J. S. The ignition at low temperatures of the organic matter in soils, 1938, 28,393

Hudson, H. G. Population studies with wheat. I. Sampling, 1939, 29, 76

HUDSON, H. G. Population studies with wheat. II. Propinquity, 1941, 31, 116

Hodson, H. G. Population studies with wheat. III. Seed rates in nursery trials and field plots, 1941, 31, 138

Humphries, E. C. and Rodriguez, G. Decomposition of cacao leaves under natural conditions, $1945,35,247$

HUNTER, H. The improvement of winter oats, 1935, 25, 419

HUNTGR, H. Relation of ear survival to the nitrogen content of certain varieties of barley. With a statistical study by H. O. Hartley, 1938, 28, 472

HUNTER-SMTtH, J., see GARDNGR, H. W. Hotchinson, J. C. D., see Deighton, T.

INNES, R. F. and BIROH, H. F. A comparison of four methods for the estima. tion of the exchangesble hydrogen content of soils, 1945, 35, 236 
IRwIs, J. O. On the influence of soil temperature on the germination interval of crops, 1931, 21, 241

Is $\triangle A C, W . E$. The rate of decay in relation to soil types and vegetative covering in Glamorgan, 1933, 23, 31

IsAaCHSEN, H. Accessory food factors. The fat-soluble vitamin requirements of cattle and pigs during growth, with remarks on some other questions as to the vitemin problem in cattle and pig feeding, 1932, 22, 460

JACQUES, W. A. Manuring of meadow-hay land. The effect of manures and lime on the botanical composition and yield of hay, 1933, 23, 146

JANRRT, H. The application of heat of wetting measurements to soil research problems, 1934, 24, 136

JENSEN, H. L. The microbiology of farmyard manure decomposition in soil. I. Changes in the microflora, and their relation to nitrification, 1931, 21, 38

JeNSEN, H. L. The microbiology of farm. yard manure decomposition in soil. II. Decomposition of cellulose, 1931, 21, 81

JeNSEN, H. L. A comparison of two agar media for counting soil micro-organisms, $1931,21,832$

Jensen, H. L. The microbiology of farmyard manure decomposition in soil. III. Decomposition of the cells of microorganisms, 1932, 22, 1

Jewit,, T. N. Dispersion studies on Gezira soil, 1941, 31, 466

JEWTT, T. N. Nitrification in Sudan Gezira soil, 1945, 35, 264

Johnson, D. A., see Woodman, R. M.

Johnstone-Wallace, D. B. and Kennedy, K. Grazing management practices and their relationship to the behaviour and grazing habits of cattle, 1944, 34, 190

Jones, C. R., see Fisher, E. A.

JUSTESEN, S. H. Influence of size and shape of plots on the precision of field experi. ments with potatoes, $1932,22,366$

Kalanikar, R. J. Experimental error and the field-plot technique with potatoes, $1932,22,373$

Kalamkar, R. J. A study in sampling technique with wheat, 1932, 22, 783

KaLAmкar, R. J. A statistical examination of the yield of mangolds from Barnfield at Rothamsted, 1933, 23, 161

KaLamkar, R. J. The influence of rainfall on the yield of mangolds at Rothamsted, $1933,23,571$

Kege, B. A. and CasheN, G. H. Studies in soil cultivation. VI. The physical effect of sheep folding on the soil, 1932, 22, 126
Keen, B. A., see also Russert, E. W.

KerleY, W. P. The formation, evolution, reclamation, and the absorbed bases of alkali soils, 1934, 24, 72

KeMSLeY, W. F. F., see HEY, G. B.

Krinnedy, $K$., see JoHnstone-Walliace, D. $\mathrm{B}$.

Kislovsky, D. A. and Larchun, B. A. The periods of embryonic growth in cattle, 1931, 21, 659

KNowLes, F. and Watkin, J. E. The assimilation and translocation of plant nutrients in wheat during growth, 1931, 21, 612

KNowles, F. and WaTkIN, J. E. The amounts and distribution of $\operatorname{som} \theta$ phosphorus and nitrogen compounds in wheat during growth, 1932, 22, 755

KNowles, F., WatkTN, J. E. and Cowie, G. A. Some effects of fertilizer interactions on growth and composition of the potato plant, 1940, 30, 159

KNOWLES, F., WATKIN, J. E. and HendRY, F. W. F. The nature of the calcium and phosphorus combination in the excreta of the non-laying pullet, 1933, 23, 196

KNoWLES, F., WATKN, J. E. and HENDRY, F. W. F. A chemical study of sugar beet during the first growth year, 1934, 24, 368 KoN, S. K., see Foot, A. S.

Koshal, R. S. The effects of rainfall and temperature on percolation through drain gauges, 1934, 24, 105

KYaw, M. H. Rapid method of standardization of the density of bull semen; 1944 , 34, 106

LACHOWER, D. The movement of potassium in irrigated and fertilized red sandy clay, $1940,30,498$

LaIne, T., see VIrTanen, A. I.

LaING, J. A. Observations on the survival of stored spermatozoa in the genital tract of the mare, 1943, 33, 64

LAING, J. A. Observations on the characteristics of the semen in relation to fertility in the bull, 1945, 35, 1

LATNG, J. A. Observations on the effect of method of management at mating on bovine fertility, 1945, 35, 25

LAING, J. A. Observations on the survival time of the spermatozoa in the genital tract of the cow and its relation to fertility, 1945, 35, 72

LAMBERT, A. R., see Gregory, F. G.

LAROHI, B. A., see KIsLOVsKY, D. A.

LEwIs, A. H. The effects of ammonium and nitrate nitrogen on the growth of perennial rye grass, 1936, 26, 249

LEWIS, A. H. The fertilizer value of some concentrated materials, particularly urea and guanidine and their nitrates and phosphates, 1936, 26, 509 
LEwIS, A. H. The effect of nitrogenous fertilizers on the calcium status of soil, $1938,28,197$

LEwIS, A. H. The placement of fertilizers. I. Root crops, 1941, 31, 295

LEwIS, A. H. The teart pastures of Somerset. II. Relation between soil and teartness, 1943, 33, 52

LEwIS, A. H. The teart pastures of Somerset. III. Reducing the teartness of pasture herbage, $1943,33,58$

LewIS, A. H. The uptake of nutrients by flax, 1943, 33, 169

Lewis, A. H. and Marmoy, F. B. The effect of ammonium sulphite on plant growth, 1933, 23, 1

Lewis, A. H., Procter, J. and Trevans, $D$. The effect of time and rate of application of nitrogen fertilizers on the yield of wheat, 1938, 28, 618

Lewis, A. H. and Strickland, A. G. The placement of fertilizers. II. Cereals, 1944, 34, 73

Lewis, A. H., see also Frerauson, W. S.

LrNes, E. W. L. An apparatus and technique for measuring the respiratory exchange of fed sheep over periods of forty-eight hours, 1938, 28, 663

Linton, R. G. The composition of mare's milk, 1931, 21, 669

Linton, R. G., WILsen, A. N. and Watson, S. J. The nutritive value of legume husks, 1934, 24, 260

LORD, L. A uniformity trial with irrigated broadcast rice, $1931,21,178$

LJGG, J. W. H. Identification and measurement of the combustible gases that occur in the gaseous metabolic products of sheep, 1938, 28, 688

MoCaLL, R. J. S., see ELDER, S.

McCallom, J. W., see Stewart, J.

Macdonald, D., Fielding, W. L. and Roston, D. F. Experimental methods with cotton. I. The design of plots for variety trials, $1939,29,35$

Macdonald, D., Fieldng, W. L. and Ruston, D. F. Experimental methods with cotton. II. A study of the effects of seed rate and time of thinning on the development and yield of cotton plants in hand-planted cotton trials, 1939, 29, 418

MCDonald, J. A., see HaRdy, F.

McDodgall, E. I., see Shearer, G. D.

Mactrone, C. and Walton, A. Fecundity of male rabbits as determined by 'dummy matings', 1938, 28, 122

Mackrntosh, J., see Foot, A. S.

McLEAN, W. Effect of hydrogen peroxide on soil organic matter, 1931, 21, 251

MoLean, $W$. The nature of soil organic matter as shown by the attack of hydrogen peroxide, 1931, 21, 595
McLEaN, W. The determination of phosphorus in soils, 1936, 26, 331

McLean, W. Note on 'the significance of the $p \mathrm{H}$ determination in the evaluation of quality in silages', 1941, 31, 518

McMahon, P. R., see Elphick, B. L.

MCMEEKAN, C. P. The nature and variability of the carcass characters of Danish and English bacon pigs, 1939, 29, 131

MoMrekan, C. P. Growth and development in the pig with special reference to carcass quality characters. I, 1940, 30, 276

MoMerkan, C. P. Growth and development in the pig with special reference to carcass quality characters. II. The influence of the plane of nutrition on growth and development, 1940, 30, 387

McMeezan, C. P. Growth and development in the pig with special reference to carcass quality characters. III. The effect of the plane of nutrition on the form and composition of the bacon pig, $1943,30,511$

MoMrenan, C. P. Growth and development in the pig, with special reference to carcass quality characters. IV. Use of sample joints and of carcass measure. ments as indices of the composition of the bacon pig. V. Bearing of the main principles emerging upon the many problems of animal production and human development, 1941, 31, 1

McMurray, M. R., see Parkhurst, R. T.

Malhotra, R. C. The distribution of some reserve substances in hard winter wheat plant at successive growth stages and their possible utilization, 1932, 22, 485

MaNN, H. H. The character of barley grown on soil made acid with sulphate of ammonia, 1937, 27, 108

MANN, H. H. Investigations on clover sickness, 1938, 28, 437

MANN, H. H. The influence of fallowing on the yield of wheat or barley on very exhausted land, 1943, 33, 207

MANN, H. H. and BARNES, T. W. Studies of soil after fifty years of wheat or barley cropping, especially of soil made acid with sulphate of ammonia, 1940, 30, 345

ManN, H. H., see also Russell, E. W.

Mann, T. B. Chick rearing. I. The effect of diet on mortality with special reference to six-day disease, $1945,35,95$

MaNs, T. B. Chick rearing. II. The bacterial syndrome arising from a diet which is conducive to six-day disease, 1945, 35, 98

MaNs, T. B. Chick rearing. III. The effect of diet on vitamin $A$, xanthophyll and carotene metabolism, 1945, 35, 101 
ManN, T. B. Chick rearing. IV. The mechanism of infection in six-day disease with special reference to intestinal putrefaction, 1945, 35, 108

MLANN, T. B. Chick rearing. V. The influence of diet on epidemic bacillary - white diarrhcea (pullorum disease), 1945, 35, 207

ManN, T. B. Chick rearing. VI. The bacterial syndrome encountered in epidemic bacillary white diarrhcea of chicks ( uullorum disease), 1945, 35, 214

Mann, T. B. Chick rearing. VII. The control of epidemic bacillary white diarrhca, 1945, 35, 225

Mank, T. B. Chick rearing. VIII. The preparation of a sensitive and diagnostic stained antigen for the rapid whole blood test for bacillary white diarrhœa of chicks, 1945, 35, 232

Marchand, B. DE C. The sticky point water of soils. II, 1931, 21, 324

Marmoy, F. B., see Lewis, A. H.

Marshail, $W$. and Cruickshank, D. B. The function of the cuticle in relation to the porosity of eggs, 1938, 28, 24

Marston, H. R. Studies on the relationship between nutrition and wool production of Merino sheep. I. The technique employed for determining the utilization of foodstuffs and for estimating the wool produced over short periods by Merino sheep, 1935, 25, 103

Marston, H. R. Studies on the relationship between nutrition and wool production of Merino sheep. II. The effect of the administration of cystine, cystein, sulphur and methionine on the growth of wool of a Merino ewe on a protein-poor ration, $1935,25,113$

MARSTON, H. R. A note on the estimation of the sulphur content of fodder and excreta, 1938, 28, 679

Martin, H. and Salmon, E. S. The fungicidal properties of certain spray-fluids. VIII. The fungicidal properties of mineral, tar and vegetable oils, 1931, 21, 638

Martin, H. and Salmon, E. S. The fungicidal properties of certain spray-fluids. IX. The fungicidal properties of the products of hydrolysis of sulphur, 1932, 22,595

MarTin, H. and $S_{\triangle L M O N}, E$. S. The fungicidal properties of certain spray-fluids. X. Glyceride oils, 1933, 23, 228

Martin, H. and Sarmon, E. S. The fungicidal properties of certain spray-fluids. XI. Synthetic solvents, 1934, 24, 469

Maris, J. T. The chemical evaluation of pyrethrum flowers (Chrysanthemum cinerariaefolium). A comparison of several methods, 1938, 28, 456
Martin, J. T. The chemical evaluation of pyrethrum flowers (Chrysanthemum ciner. ariaefolium). The extraction of the flowers for analysis and the preparation of colourless concentrates of the pyrethrins, 1941, 31, 178

Martin, J. T. and Tattrasfield, F. The evaluation of pyrethrum flowers (Chrysanthemum cinerariaefolium), 1931, 21, 115

Martin, J. T., see also TAtTERsfield, F.

Mather, $K$. and ANDERsson, $G$. The determination of winter hardiness in oats, $1934,24,627$

Menta, N. P., see Russell, E. W.

Menchirovsky, F. Pan (Nasas) and its origin in the red sandy soils of Palestine, $1932,22,689$

Menzies-KItchrs, A. W. Fertility, mortality and growth rate in pigs, 1937, 27, 611

Menzies-Krtchin, A. W., see also WoodMAN, H. E.

Meyer, H., see Bondr, A. H.

Mmton, W. E. J., see Chippindale, H. G.

Mtrchandant, T. J. The effects of summer green manures on the ammonia and nitrate contents of soils cropped for winter wheat. An examination of the Woburn green manure plots, 1931, 21, 458

Mrrchandant, T. J., see also Crowther, E. M.

MrTckell, R. L. The base status of Scottish soils. I. The effects of lime on five typical soils from north-east Scotland, $1936,26,664$

Mrtchex, R. R. Base exchange equilibria in soil profiles, 1937, 27, 557

Moon, F.E. The quantitative extraction of carotene from grass, 1939, 29, 295

Moon, F. E. The influence of manurial treatment on the carotene content of pasture grass, and on the relationship of this constituent to the ash and organic fractions, 1939, 29, 524

Moon, F. E. and Thomas, B. The digestion of huskless oats by poultry, 1937, 27, 458

Morris, S., see WHSON, W. K.

MURerJI, B. K. Studies on calcium cyanamide. II. Micro-biological aspects of nitrification in soils under varied environmental conditions, 1932, 22, 335

MoNRo, S. S. The relation of production to mortality in the domestic fowl, 1936, 26, 101

Morray, A. The quality factor in feeding - stuffs, 1933, 23, 185

MurRay, G. N., see Hammond, J.

MORRAY, R. K. S. The value of a uniformity trial in field experimentation with rubber, 1934, 24, 177 
NAGELSCHMTDT, G. The identification of minerals in soil colloids, 1939, 29, 477

Neave, O., see Frrauson, W. S.

Nemson-Jones, W. Biological aspects of soil fertility, 194I, 31, 379

NICHOLs, J. E. Wool characters in 'halfbred' sheep (Border Leicester rams $x$ Cheviot ewes), 1933, 23, 473

Nicholson, $H$. H. The effects of varied dressings of ground limestone in the field, 1931, 21, 262

Nicholson, H. H. The durability of mole drains, 1934, 24, 185

Nrcholson, H. H. The role of field drains in removing excess water from the soil. I. Some observations on rates of flow from outfalls, 1934, 24, 349

Nicholson, H. H. and Chrids, E. C. The transport of water through heavy clay soils. II, 1936, 26, 128

Nicol, H., see Thornton, H. G.

NormaN, A. G. A preliminary investigation of the development of structural constituents in the barley plant, 1933, 23, 216

Norman, A. G. The composition of crude fibre, $1935,25,529$

Norman, A. G., see also Watson, D. J.

Norman, D. B., see Woodman, H. E.

NowotNówNa, A. An investigation of nitrogen uptake in mixed crops not re. ceiving nitrogenous manure, 1937, 27, 503

Nowotny, A., see NowOtNówna, A.

Normia, M., see Virtanen, A. I.

O'Donohor, F., see WaLsh, T.

OLBRYCHT, T. M. The statistical basis of selection in animal husbandry. I. Studies on life performance of brood sows: an analysis of variance and covariance of progeny born and reared, $1943,33,28$

OLBRYCHT, T. M. The statistical basis of selection in animal husbandry. II. Studies on life performance of brood sows: the judging of brood sows by their number of offspring born and reared in the earliest litters, 1943, 33, 74

OrbRYCHT, T. M. Behaviour of some external characteristics in Essex pigs, $1944,34,16$

Oosthulzen, P. M., see Woodman, H. E.

Owen, E. C., SNow, D. and THOM, C. L. The effect of borax dressings on the growth and yield of field beans (Vicia faba L.), 1945, 35, 119

OWEN, 0 . The analysis of tomato plants. II. The effect of manurial treatment on the composition of tomato foliage, 1931, 21, 442

$P_{A G E}, H$. J. Studies on the carbon and nitrogen cycles in the soil. V. The origin of humic matter of the soil, 1932, 22, 291
PaGe, H. J., see also Do TotT, M. M. S., GreenhmL, A. W. and Hobson, R. K.

PaI, B. P., see Engledow, F. L.

PÁlsson, H. Meat qualities in the sheep with special reference to Scottish breeds and crosses. I, 1939, 29, 544

PÁsson, H. Meat qualities in the sheep with special reference to Scottish breeds and crosses. II. Part III. Comparative development of selected individuals of different breeds and crosses as lambs and hoggets, 1940, 30, 1

Parker-Rhodes, A. F. Investigations on certain toxic substances obtained from the wheat plant which inhibit the germination of the uredo-spores of various wheat rusts, $1939,29,399$

Parkes, A. S., see Hammond, J. jun.

PARkhurst, R. T. and McMUrRay, M. R. The relation of calcium and phosphorus to growth and rachitic leg weakness in chickens, 1932, 22, 874

Parkhorst, R. T. and Momurray, M. R. Factors in the development of deforming leg weakness in chickens, 1933, 23, 311

Paterson, D. D. The influence of time of cutting on the growth, yield and composition of tropical fodder grasses. I. Elephant grass (Pennisetum purpureum), $1933,23,615$

Paterson, D. D. The growth, yield and composition of certain tropical fodders, $1935,25,369$

Paver, H., see Woodman, R. M.

Penman, H. L. Gas and vapour movements in the soil. I. The diffusion of vapours through porous solids, 1940, 30, 437

Penman, H. L. Laboratory experiments on evaporation from fallow soil, 1941, 31, 454

Penman, H. L. and Schofield, R. K. Drainage and evaporation from fallow soil at Rothamsted, 1941, 31, 74

Pereira, H. C. Studies in soil cultivation. IX. The effect of inter-row tillage on the yield of potatoes, 1941, 31, 212

Peto, R. H. K., see Grenne, $\mathrm{H}$.

PetTit, G. H. N. Wastage, length of productive life, replacement and deprecia. tion of dairy cows, 1940, 30, 485

Pettit, G. H. N., see also Yates, F.

PIPER, C. S. The availability of manganese in the soil, 1931, 21, 762

PIPER, C. S. The determination of sodium by precipitation as the triple salt sodiumuranyl-magnesium acetate, 1932, 22, 676

PIPER, C. S. Marsh spot of peas: a manganese deficiency disease, $1941,31,448$

PIPER, C. S. Investigations on copper deficiency in plants, $1942,32,143$ 
Prtcarthly, N. P. and Worlex, F. P. Distribution of copper in the Karaka tree (Corymocarpus laevigata), 1933, 23, 204

Pizer, N. H. Investigations into the environment and nutrition of the cultivated mushroom Psalliota campestris. I. Some properties of composts in relation to the growth of the mycelium, 1937, 27, 349

Pizer, N. H. and Thompson, A. J. Investigations into the environment and nutrition of the cultivated mushroom (Psalliota campestris). II. The effect of calcium and phosphate on growth and productivity, $1938,28,604$

Pomeroy, $R$. W. The effect of a submaintenance diet on the composition of the pig, 1941, 31, 50

Ponteconvo, G. Allometric growth of the forelimb in cattle, 1939, 29, 111

Poole, H. G., see Prescott, J. A.

Prescott, J. A. and Poole, H. G. The relationships between sticky point, moisture equivalent, and mechanical analysis in some Australian soils, 1934, 24, 1

Procter, J., see Lewis, A. H. and WATson, S. J.

Puri, A. N. and Puri, B. R. Ultramechanical analysis of soils, 1941, 31, 171

Puri, B. R., see Purr, A. N.

Purvis, O. N., see Hatcher, E. S. J.

Ramers, J. H. W. Th. and Bartel, L. H. The retention of protein by growing pigs, $1935,25,397$

RHOAD, A. O. The influence of environmental temperature on the respiratory rhythm of dairy cattle in the tropics, $1936,26,36$

RIOHARDS, E. H. Note on the effect of temperature on a mixed culture of two organisms in symbiotic relation, 1939 , 29, 302

Richardson, E. G. Cohesion and viscosity of clays, 1933, 23, 176

Riorardson, E. G. An optical method for mechanical analysis of soils, etc., 1934, 24, 457

RICHaRdson, H. L. Studies on calcium cyanamide. III. Storage and mixing with superphosphate, 1932, 22, 348

RICHARDSON, H. L. Studies on calcium cyanamide. IV. The use of calcium cyanamide and other forms of nitrogen on grassland, 1934, 24, 491

Richardson, H. L. The nitrogen eycle in grassland soils: with especial reference to the Rothamsted Park grass experiment, $1938,28,73$

Richardson, H. L. and Crowther, E. M. Studies on calcium cyanamide. V. The utilization of calcium cyanamide in pot culture experiments, 1935, 25, 132
Richardson, H. L., see also CaLdwell, J. and Crowther, E. M.

Robi, W., see SMITH, A. M.

Roberts, J. A. F., see Fraser, A. H. H.

ROBERTSON, I. M., see SMITH, A. M.

Robison, C. J., see Smith, A. D. B.

RODRIGUEz, G., see also HARDY, F. and HUMPHRIES, E. C.

Rookrs, W. S. A soil moisture meter depending on the 'capillary pull' of the soil. With illustrations of its use in fallow land, grass orchard, and irrigated orchards, $1935,25,326$

Romanofr, A. L. Influence of incubation temperature on the hatchability of eggs, post-natal growth and survival of turkeys, 1935, 25, 318

Russeit, E. W. The present position of the theory of the coagulation of dilute clay suspensions. A résumé, 1932, 22, 165

Rosseit, E. W. The significance of certain 'single value' soil constants, 1933, 23, 261

RusserL, E. W. The subdivision of the clay fraction in mechanical analysis, 1943,33 , 147

Russell, E. W. and Balcerer, W. The determination of the volume and air space of soil clods, 1944, 34, 123

RUSSELL, E. W. and GUPTA, R. S. On the measurement of imbibitional water, $1934,24,315$

RUSSELl, E. W., Hine, H. J. and Keen, B. A. The efficiency of pneumatic tyred tractors under farm conditions, 1942, 32, 1

RusSeLL, E. W. and KEEN, B. A. Studies in soil cultivation. VII. The effect of cultivation on crop yield, 1938, 28, 212

Rossert, E. W. and KeEN, B. A. Studies in soil cultivation. $X$. The results of a sixyear cultivation experiment, 1941, 31, 326

Rosselt, E. W., Keen, B. A. and ManN, H. H. Studies in soil cultivation. XI. The effect of inter-tillage on the sugar. beet crop, 1942, 32, 330

Russerl, E. W. and Menta, N. P. Studies in soil cultivation. VIII. The influence of the seed bed on crop growth, 1938, 28, 272

Russert, E. W. and Tambane, R. V. The determination of the size distribution of soil clods and crumbs, 1940, 30, 210

Russmit., J. L. Scientific research in soil drainage, 1934, 24, 544

Ruston, D. F., see Macdonald, D.

Rutledge, W. A. and Common, R. H. The composition and digestibility of Northern Irish rye-grass seed cleanings. II. Data for 'flatweed', 'hairgrass', and commercial Yorkshire fog seed, with a note on inorganic constituents, 1945, 35, 123 
Sarri, P. N. The relation of drainage to rainfall and other meteorological factors, 1941, 31, 110

Salaado, M. L. M. A study of the exchangeable bases of some East Anglian soils derived from the Jurassic and Cretaceous sediments, with special reference to their marine origin, 1933, 23, 18

Salmon, E. S., see MarTin, H.

SANDERS, H. G., see GarNer, F. H.

Sohofield, R, K. Rapid methods of examining sols. II. The use of $p$. nitrophenol for assessing lime status, $1933,23,252$

ScHofiend, R. K. Rapid methods of examining solls. III. The use of di. hydrogen potassium phosphate in studying base exchange capacity, 1933, 23, 255

Schofield, R. K, and BraIR, G. W. S. Rapid methods of examining soils. I. Measurements of rolling weights, 1932 , 22, 135

SChofreid, R. K. and Costa, J. V. B. DA. The measurement of $p \mathrm{~F}$ in soil by freezing-point, 1938, 28, 644

Schofield, R. K., see also Davidson A. L. C. and Penman, H. L.

Selwy, H. H., see ShUTT, F. T.

$\mathrm{SEN}, \mathrm{A}$. The measurement of electrical conductivity of aqueous soil suspension and its use in soil fertility studies, 1932, 22,212

SEN, A. and Wright, C. H. The electrical conductivity of aqueous soil suspensions as a measure of soil fertility, 1931, 21, 1

SEN, H. D. A study on the extraction of papain, the active digestive principle from Papaya, 1931, 21, 209

Sen, K. C., see Seshan, P. A.

Seshan, P. A. and Sen, K. C. Studies on carotene in relation to animal nutrition. I. The technique of carotene estimation in feeding stuffs, 1942, 32, 194

Seshan, P. A. and Sen, K. C. Studies on carotene in relation to animal nutrition. II. The development and distribution of carotene in the plant and the carotene content of some common feeding stuffs, $1942,32,202$

Seshan, P. A. and Sen, K. C. Studies on carotene in relation to animal nutrition. III. Stability of carotene in plant material with special reference to hay making and storage, 1942, 32, 275

Sespha , P. A. and Ser, K. C. Studies on carotene in relation to animal nutrition. IV. Carotene balance experiments with cows and bullocks, 1942, 32, 286

Shearer, G. D. and McDovgall, E. I. Some observations on swayback disease of lambs, 1944, 34, 207

ShEery, E. J. Methods of experimentation in animal nutrition, $1934,24,312$
ShEwan, J. M. The proximate analysis of the organic constituents in north-east Scottish soils, with some notes on the methods, 1938, 28, 324

Shorland, F. B. and De La Mare, P. B. D. Studies on the fats of the bacon pig with reference to carcass quality. The effect of diet on the component fatty acids of the back fat, $1945,35,33$

Shorland, F. B. and DE La Mare, P. B. D. Studies on the fats of the bacon pig with reference to carcass quality. The relation between growth rate and chemical composition of depot fat, 1945, 35, 39

Shrikhande, J. G. A new method for the determination of total phosphoric acid in soils, 1942, 32, 406

Shutr, F. T. and Hammton, S. N. The close-grazing scheme of pasture management. The influence of successive applications of nitrogen on the composition and yield of the herbage, 1934, 24, 341

ShUT, F. T., Hammion, $S . \quad N$. and SELwYN, H. H. High-protein pasture. The rotational or close-grazing system of pasture management, $1932,22,647$

SrEBENGA, J., see EDWARDS, J.

Sirk, B. J., see WaIN, R. L.

Srmpson, T. W. Studies in sampling technique: cereal experiments. II. A small-scale threshing and winnowing machine, 1931, 21, 372

Smrth, A. D. B. and Donald, H. P. Weaning weight of pigs and litter sampling with reference to litter size, $1937,27,485$

Smrth, A. D. B. and Donald, H. P. Analysis of post-weaning growth in pigs, $1939,29,274$

Smith, A. D. B. and Rosison, O. J. The average ages of cows and bulls in six breeds of cattle, 1931, 21, 136

Smrth, A.M. and Comrre, A. The composition of different kinds of silage, 1938, 28, 203

Smrth, A. M. and RobB, W. The carotene and protein in oats and barley at different stages of growth, 1943, 33, 119

Smith, A. M. and Robertson, I. M. The influence of the plant upon seasonal changes in soil acidity, 1931, 21, 822

SmITh, A. M. and WANG, T. The carotene content of certain species of grassland herbage, 1941, 31, 370

Smrth, H. F. An empirical law describing heterogeneity in the yields of agricultural crops, 1938, 28, 1

SмIтн, J. A. B., see SNow, D.

Snow, D., Sмгтн, J. A. B. and Wright, N. C. The manufacture and storage of cereal feeding-stuffs with incorporated non-protein nitrogen compounds, 1945 , 35, 65 
Swow, D. and Wright, N. C. The respira. tion rate and loss of dry matter from stored bran, $1945,35,126$

SNow, D., see also OWEN, E. C.

Snow, O. W., see Greene, H.

Sremervasan, A. and Subrahmanyan, V. Biochemistry of water-logged soils. Part IV. Carbon and nitrogen transformations, 1935, 25, 6

STEPHENS, S. G. Yield characters of selected oat varieties in relation to cereal breeding technique, 1942, 32, 217

SteWART, A. B. The genesis and development of two profiles of drift soil in the north-east of Scotland, 1933, 23, 73

STEWART, A. B. Soil properties in relation to the occurrence of grass sickness in horses, 1941, 31, 308

Stewart, A. B., see also Whltams, E. G.

S'tewart, J. and McCallom, J. W. The vitamin A content of the colostrum of dairy cows, 1938, 28, 428

Stewart, J., see also Woodman, H. E.

StrangewaYs, D. H. The study of the conditions and factors affecting hair growth in the guinea-pig, 1933, 23, 359

Strangeways, D. H. The effect of preg. nancy on hair growth and shedding in the guinea-pig, 1933, 23, 379

StricklaNd, A. G., see Lewis, A. H.

SubrahmanyaN, V., see Sreentvasan, A.

Tamhane, R. V., see Russelt, E. W.

TatTersfield, F. The loss of toxicity of pyrethrum dusts on exposure to air and light, 1932, 22, 396

TATTERSFIELD, F. and Martin, J. T. The loss of activity of pyrethrum. II, 1934 , 24,598

Tatrersfierd, F., see also Martin, J. T.

TAYLOR, E. L. The epidemiology of parasitic gastritis in sheep. Observations on the relative importance of the various factors concerned in the development of the disease, 1934, 24, 192

TAYLOR, R. E. and WESTON, W. A. R. D. Seed disinfection. VI. Stripe smut of rye, $1945,35,116$

TAYLOR, R. E., see also WeSTON, W. A. R. D.

Tedin, $O$. The influence of systematic plot arrangement upon the estimate of error in field experiments, 1931, 21, 191

Temperton, $H$. and Dudley, F. J. The feeding of raw and cooked potatoes and sugar beet to laying pullets, 1943, 33, 204

Templeman, W. G., see Blackman, G. E.

Thом, C. L., see OWEN, E. C.

Tномаs, B. On the composition of common heather (Calluna viulgaris), 1934, 24, 151

Tromas, B. and Ersurot, F. J. On the yields and composition of pasture grass from the Tree Field Plots of Cockle Park, $1932,22,736$
Thomas, B., see also Eurotr, F. J., and Moon, F. E.

Thomasset, L. F. A study of the development of the characters of the fleece during growth in the different regions of the body, 1938, 28, 523

Thompson, A. J., see Przer, N. H.

Thompson, W. B., see Davies, W. M.

Thomson, W., see Duckworth, J.

Thornton, H. G. and Nicor, H. The effect of sodium nitrate on the growth and nitrogen content of a lucerne and grass mixture, 1934, 24, 269

Thornton, H. G. and Nicol, H. Some effects of clipping the tops upon the root development of lucerne (Medicago sativa L.), 1934, 24, 532

Thornton, H. G. and Nroor, H. Further evidence upon the nitrogen uptake of grass grown with lucerne, 1934, 24, 540

Thornton, H. G. and Nicot, H. Reduction of nodule numbers and growth, produced by the addition of sodium nitrate to lucerne in sand culture, 1936, 26, 173

Trtus, H. W., see Hendricks, W. A.

Trevains, D., see Lewis, A. H.

Troele, E. The use of sodium hypobromite for the oxidation of organic matter in the mechanical analysis of soils, 1931, 21, 476

Turner, P. E. An analysis of factors contributing to the determination of saturation capacity in some tropical soil types, 1932, 22, 72

TurpitT, W. G., see Woodman, H. E.

Traany-Ryadno, M. The relations of Bacillus mycoides with ammonification, nitrification, and soil fertility, 1933, 23, 335

Truer, C. The porosity of egg shells and the influence of different levels of dietary calcium upon porosity, 1945, 35, 168

TrLer, C. and WIILcox, J. S. Calcium and phosphorus balances with laying birds, $1942,32,43$

Tyuer, C. and Willcox, J. S. The calcium requirements of poultry with particular reference to their needs for maintenance, $1942,32,62$

UNDERWOOD, E. J., see WOODMAN, H. E.

Fartiovaara, U. Investigations on the root nodule bacteria of leguminous plants. XXI. The growth of the root-nodule organisms and inoculated peas at low temperatures, 1937, 27, 626

VASEY, A. J., see Forster, H. C.

VIRTanen, A. I. and von Hauser, S. Investigations on the root nodule bacteria of leguminous plants. XVI. Effect of air content of the medium on the function of the nodule and on the excretion of nitrogen, 1935, 25, 278 
Vmranes, A. I. and von Hadsen, S. Investigations on the root nodule bacteria of leguminous plants. XVII. Efficiency of different strains of clover nodule bacteria, 1935, 25, 290

VIrTaneN, A. I, and von HaUSeN, $S$. Investigations on the root nodule bacteria of leguminous plants. XVIII. Continued investigations on the effect of air content of the medium on the development and function of the nodule, 1936, 26, 281

VrrtaneN, A. I., voN HaUSEN, $S$. and LaINe, $T$. Investigations on the root nodule bacteria of leguminous plants. XIX. Influence of various factors on the excretion of nitrogenous compounds from the nodules, 1937, 27, 332

VIRTANEN, A. I., voN HAUSEN, S. and LAINE, T. Investigations on the root nodule bacteria of leguminous plants. $\mathrm{XX}$. Excretion of nitrogen in associated cultures of legumes and non-legumes, $1937,27,584$

VtrTanen, A. I. and Nurmis, M. Studies on the winter hardiness of clover. I. Effect of cutting on the carbohydrate reserves in red clover roots, 1936, 26, 288

WAIN, R. L., SHK, B. J. and Wrus, B. C. The fate of manganese sulphate in alkaline soils, $1943,33,18$

WAIN, R. L., see also GLASSCOCK, H. H.

WALKLEY, A. An examination of methods for determining organic carbon and nitrogen in soils, 1935, 25, 598

WALSK, T. and O'DonoHoe, F. Magnesium deficiency in some crop plants in relation to the level of potassium nutrition, 1945, 35,254

WaLSh, T., see also Gallagher, P. H.

WaltoN, A., see EDwards, J. and Macirone, C.

Wang, T., see Smtth, A. M.

WARD, A. H. and Camprell, J. T. The practical application of age conversion factors to dairy cattle production (butterfat) records, 1938, 28, 509

WATRrN, J. E., see KrowLES, F.

Watson, D. J. The effect of applying a nitrogenous fertilizer to wheat at different stages of growth, 1936, 26, 391

WatSON, D. J. The estimation of leaf area in field crops, 1937, 27, 474

Watson, D. J. Field experiments on the effect of applying a nitrogenous fertilizer to wheat at different stages of growth, $1939,29,379$

Watson, D. J. and Norman, A. G. Photosynthesis in the ear of barley, and the movement of nitrogen into the ear, 1939 , 29, 321

Watson, D. J., see also Yates, F.

Watson, H. M. S., see Botromeny, A. C.
Watson, S. J. The digestibility and feeding value of dreg meal, 1931, 21, 410

Watson, S. J. Investigations into the intensive system of grassland management by the Agricultural Research Staff of Imperial Chemical Industries, Limited. IV. The digestibility and feeding value of artificially dried grass, 1931, 21, 414

Watson, S. J. Investigations into the intensive system of grassland management by the Agricultural Research Staff of Imperial Chemical Industries, Limited. $V$. The digestibility and feeding value of grass silage made in a tower, and the digestibility and comparative yreld of artificially dried grass obtained from the same source, 1931, 21, 425

WATSON, S. J. Investigations into the intensive system of grassland management by the Agricultural Research Staff of Imperial Chemical Industries, Limited. VI. The digestibility and feeding value of grass silage made in a stack, 1931, 21, 452

WATSON, S. J. Investigations into the intensive system of grassland management by the Agricultural Research Staff of Imperial Chemical Industries, Limited. VII. The digestibility and feeding value of grass silage made in a pit, 1931, 21, 469

Watson, S. J. and Ferauson, W. S. Investigations into the intensive system of grassland management by the Agricultural Research Staff of Imperial Chemical Industries, Limited. VIII. The comparative digestibility and feeding value of fresh and artificially dried grass, $1932,22,235$

WATSON, S. J. and Fergoson, W. S. Investigations into the intensive system of grass. land management by the Agricultural Research Staff of Imperial Chemical Industries, Limited. IX. The digestibility of artificially dried hay, 1932, 22, 247

Watson, S. J. and Frrguson, W. S. The nutritive value of artificially dried grass and its effect on the quality of milk produced by cows of the main dairy breeds, 1936, 26, 189

Watson, S. J. and Ferguson, W. S. The value of artificially dried grass, silage made with added molasses and A.I.V. fodder in the diet of the dairy cow and their effect on the quality of the milk, with special reference to the value of the non-protein nitrogen, 1936, 26, 337

Watson, S. J. and Frrouson, W. S. The chemical composition of grass silage, $1937,27,1$

Watson, S. J. and Frradson, W. S. The losses of dry matter and digestible nutrients in low-temperature silage, with and without added molasses or mineral acids, 1937, 27, 67 
Watson, S. J., Ferguson, W. S. and HorToN, E. A. The time of cutting hay, and the losses entailed during haymaking, 1937, 27, 224

Watson, S. J. and Horton, E. A. Composition, digestibility and nutritive value of samples of grassland products, 1936, 26, 142

Watson, S. J., Procter, J. and Ferguson, W. S. Investigations into the intensive system of grassland management by the Agricultural Research Staff of Imperial Chemical Industries, Limited. XI. The effect of nitrogen on the yield, composition and digestibility of grassland herbage, 1932, 22, 257

Watson, S. J., see also ALLEN, L. A., Ferauson, W. S. and LINTon, R. G.

Watson, W. A., see Doyne, H. C.

WEST, E. S. The value of 'sticky point' determinations in field studies of soil moisture, 1931, 21, 799

Weston, W. A. R. D. and Booer, J. R. Seed disinfection. I. An outline of an investigation on disinfectant dusts containing mercury, 1935, 25, 628

WhStON, W. A. R. D., HANLeY, F. and BOOER, J. R. Seed disinfection. II. Large-scale trials on the disinfection of seed corn with mercury dust disinfectants, $1937,27,43$

WeSTON, W. A. R. D. and TAYLOR, R. E. Observations on ergot in cereal crops, $1942,32,457$

Weston, W. A. R. D. and TAYLOR, R. E. Seed disinfection. $V$. The stripe diseases of barley and oat, 1943, 33, 23

Weston, W. A. R. D. and TAYLOR, R. E. Development of mould on the cut surfaces of potato tubers, 1944, 34, 93

Weston, W. A. R. D. and TAYLoR, R. E. Seed disinfection. VII. Mechanical principles, 1945, 35, 239

Weston, W. A. R. D., see also BenL, G. D. H., Bretr, C. C. and TAYLOR, R. E.

WhemaN, L. A. The base status of Scottish soils. II. Further studies of the effects of lime on typical soils from north-east Scotland, 1939, 29, 306

WheTHAM, E. O. Factors modifying egg production with special reference to seasonal changes, 1933, 23, 383

White, W. J., see Armstrong, J. M.

Whitrues, C. L. Note on a method for the preparation of permanent records of soil colour, 1931, 21, 189

Wrulcox, J. S. The nitrogen balance of laying hens, 1934, 24, 636

Willcox, J. S., see also TYLER, C.

Winliams, E. G. and STeWart, A. B. Studies on phosphate fixation in Scottish soils. I. The recovery of added phosphate from a soil of the acid igneous group, $1943,33,179$
WILLIAMS, H. R., see GaRdNeR, H. W.

Wriliams, $R$. The determination of exchangeable bases in carbonate soils, 1932, 22, 838

Wrusams, $R$. The contribution of clay and organic matter to the base exchange capacity of soils, 1932, 22, 845

Williams, $R$. The solubility of soil phosphorus and other phosphorus compounds in sodium hydroxide solutions, 1937, 27, 259

Williamson, G. The effect of Beckmann's treatment by sodium hydroxide on the digestibility and feeding value of barley straw for horses, 1941, 31, 488

WILLS, B. C., see WAIN, R. L.

Wisson, A. N., see Linton, R. G.

Wilson, P. W. and Burton, J. C. Excretion of nitrogen by leguminous plants, 1938, 28, 307

WrLSON, W. K. and Morris, S. Studies in the composition of rabbit carcasses, 1932, 22, 453

Wilson, W. K., see also DUDLEY, F. J.

Wishart, J. Field experiments of factorial design, 1938, 28, 299

Wishart, J. and HAMmond, J. A statistical analysis of the inter-relations of litter size and duration of pregnancy on the birth weight of rabbits, 1933, 23, 463

Wishart, J., see also Woodman, H. E.

Woodman, H. E. and EDEN, A. Nutritive value of lucerne. III. The composition, digestibility, and nutritive value of lucerne hay, lucerne meal (English and American) and lucerne leaf meal (American), 1935, 25, 50

Woodman, H. E. and Evans, R. E. The value of degermed maize meal (cooked) in the nutrition of swine, 1932, 22, 670

Woodman, H.E. and Evans, R. E.The determination of total sulphur and sulphate sulphur in feeding stuffs, $1933,23,459$

Woodman, H. E. and Evans, R. E. Nutritive value of lucerne. IV. The leafstem ratio, 1935, 25, 578

Woodman, H. E. and Evans, R. E. The composition and digestibility, when fed to pigs, of three grades of meat meal of widely differing fat content, 1937, 27, 465

Woodman, H. E. and Evans, R. E. The mechanism of cellulose digestion in the ruminant organism. IV. Further observations from in vitro studies of the behaviour of rumen bacteria and their bearing on the problem of the nutritive value of cellulose, 1938, 28, 43

Woodman, H. E. and Evans, R. E. Nutritive value of pasture. XII. The infuence of cutting at monthly intervals over nine seasons on the quality and productivity of a heavy-land pasture, $1938,28,581$ 
Woodman, H, E. and Evans, R. E. Nutritive value of pasture. XIII. An enquiry into the residual effects of the intensive use of sulphate of ammonia on pastures, 1938, 28, 592

Woodman, H. E. and Evans, R. E. The composition and digestibility, when fed to pigs and sheep, of potato cossettes and potato meal, 1939, 29, 347

Woodman, H. E. and Evans, R. E. Nutrition of the bacon pig. IV. The influence on growth, conformation and carcass quality of including meat meals of widely differing fat content in the rations of bacon pigs, 1939, 29, 502

Woopman, H. E. and Evans, R. E. The nutrition of the bacon pig. V. The minimum level of protein intake consistent with quick growth and satisfactory carcass quality (Part II), 1940, 30,83

Woodman, H. E. and Evans, R. E. The composition and nutritive value, when fed to ruminants, of pea-pod meal and broad-bean-pod meal, 1940, 30, 189

Woodman, H. E. and Evans, R. E. The nutrition of the bacon pig. VI. The minimum level of protein intake consistent with quick growth and satisfactory carcass quality (Part III), 1941, 31, 232

Woonman, H. E. and Evass, R. E. The nutrition of the bacon pig. VII. The chemical composition, digestibility and nutritive value of different types of swill, 1942, 32, 85

Woodman, H. E. and Evans, R. E. Further investigations of the feeding value of artificially dried potatoes: the composition and nutritive value of potato cossettes, potato meal, potato flakes, potato slices and potato dust, 1943, 33, 1

Woodman, H. E. and Evass, R. E. The value of potato peelings in the nutrition of the bacon pig, $1943,33,15$

Woodman, H. E. and Evans, R. E. The nutrition of the bacon pig. VIII. The value of lawn-grass cuttings in the feeding of bacon pigs, 1943, 33, 101

Woodman, H. E. and Evans, R. E. The nutrition of the bacon pig. IX. The Lehmann method of pig feeding, with particular reference to the balance of the basal meal and the use of cooked potatoes and molassed beet pulp as the supplemental food, 1943, 33, 155

Woodman, H. E. and Evans, R. E. The influence of war-time milling control on the composition, digestibility and nutritive value of the wheaten offals, 1944 , 34, 35
Woodman, H. E. and Evans, R. E. Further investigations of the nutritive value of swill: starch equivalent, and seasonal variation in the composition and feeding value of concentrated swill, 1944 , 34, 110

Woodmax, H. E. and Evans, R. E. The chemical composition and nutritive value of the pea-canning by-products (green pea pods, pea-pod meal, pea-pod silage and molassed silage from pea haulms with pods), 1944, 34, 155

Woodman, H. E. and Evans, R. E. The nutrition of the bacon pig. $X$. The value of extracted palm-kernel meal in the feeding of the bacon pig, 1945, 35, 44

Woodman, H. E. and EvaNs, R. E. Nutrition of the bacon pig. XI. The minimum level of protein intake consistent with quick growth and satisfactory carcass quality (Part IV), 1945, 35, 133 . Woodman, H. E., Evans, R. E., Callow, E. H. and WISHART, J. The nutrition of the bacon pig. I. The influence of high levels of protein intake on growth, conformation and quality in the bacon pig, $1936,26,546$

Woodman, H. E., Evans, R. E. and Eden, $A$. The composition and nutritive value of marrow stem kale and thousand head kale, 1936, 26, 212

Woodman, H. E., Evans, R. E. and EDEN, A. Sheep nutrition. I. Measurements of the appetites of sheep on typical winter rations, together with a critical study of the sheep-feeding standards, 1937, 27, 191

Woodman, H. E., Evans, R. E. and Eden, A. Sheep nutrition. II. Determinations of the amounts of grass consumed by sheep on pasturage of varying quality, $1937,27,212$

Woodman, H. E., Evans, R. E. and MenzIES-KITCHIN, A. W. The value of oats in the nutrition of swine, 1932, 22, 657

Woodman, H. E., Evans, R. E. and Norman, D. B. Nutritive value of lucerne. I. Preliminary studies of yield, composition and nutritive value (season 1932), 1933, 23, 419

Woodmas, H. E., Evans, R. E. and Normas, D. B. Nutritive value of lucerne. II. Investigations into the influence of systematic cutting at three different stages of growth on the yield, composition and nutritive value of lucerne, 1934, 24, 283

Woodman, H. E., Evans, R. E. and Oosthuizen, P. M. Nutritive value of pasture. XIV. The influence on yield and composition of a single heavy dressing of sulphate of ammonia, compared with that of periodic small dressings throughout the season, 1938, 28, 598 
Woodman, H. E., Evans, R. E. and TURPIT, W. G. The nutrition of the bacon pig. II. The influence of highprotein intake on protein and mineral metabolism, 1937, 27, 569

Woodman, H. E., Evans, R. E., Turpitt, W. G. and CaLLOW, E. H. The nutrition of the bacon pig. III. The minimum level of protein intake consistent with quick growth and satisfactory carcass quality (Part I), 1939, 29, 115

Woodian, H. E., Menztes-Krtchtn, A. W. and Evans, R. E. The value of tapioca flour and sago pith meal in the nutrition of swine, 1931, 21, 526

Woodman, H. E. and Norman, D. B. Nutritive value of pasture. IX. The influence of the intensity of grazing on the yield, composition and nutritive value of pasture herbage, 1932, 22, 852

WOodMaN, H. E. and NoRMaN, D. B. Nutritive value of pasture. $X$. The utilization of young grass by swine, 1934, 24, 93

Woodman, H. E., Norman, D. B. and French, M. H. Nutritive value of pasture. VIT. The influence of the intensity of grazing on the yield, composition and nutritive value of pasture herbage, 1931, 21, 267

Woodman, H. E. and Oosthutzen, P. M. Nutritive value of pasture. XI. The composition and nutritive value of winter pasturage, 1934, 24, 574

W'oopman, H. E. and Stewart, J. The mechanism of cellulose digestion in the ruminant organism. III. The action of cellulose-splitting bacteria on the fibre of certain typical feeding stuffs, $1932,22,527$

IPOODMaN, H. E. and UNDERWOOD, E. J. Nutritive value of pasture. VIII. The influence of intensive fertilizing on the yield and composition of good permanent pasture (seasons 1 and 2), 1932, 22, 26

WoOdMaN, R. M. Studies in the nutrition of vegetables. Phosphate deficiency and yield tests on sand cultures of May King lettuce, 1939, 29, 229

Woodran, R. M. and Jornson, D. A. The response of the carrot to water supply and fertilizer on a gravel soil, 1944, 34, 82
Woonman, R. M. and Paver, H. The effect of time of application of inorganic nitrogen on the turnip, 1944, 34, 49

Woodman, R. M. and Paver, H. The nutrition of the carrot. II. Grown in a fen soil, $1945,35,30$

Worley, F. P., see Pitcaithly, N. P.

Wright, C. H., see Sen, A.

WRToHT, M. D. The vitamin $D_{3}$ requirement of pullet chicks: the relative values of genuine and a sample of controlled cod-liver oil in feeding poultry up to the age of 16 meeks, 1941, 31, 161

WRIGHT, N. C. The storage of artificially dried grass, 1941, 31, 194

Wrrart, N. C., see also SNow, D.

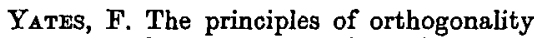
and confounding in replicated experiments, 1933, 23, 108

YATES, F. A complex pig-feeding experiment, 1934, 24, 511

YATIS, F. Incomplete Latin squares, 1936, 26, 301

Yates, F. A new method of arranging variety trials involving a large number of varieties, 1936, 26, 424

Yates, F., Boyd, D. A. and Pettit, G. H. N. Influence of changes in level of feeding on milk production, 1942, 32, 428

Yates, F. and Cochran, W. G. The analysis of groups of experiments, 1938, 28,556

YaTES, F. and WATSON, D. J. Factors influencing the percentage of nitrogen in the barley grain of Hoosfield, 1939, 29, 452

YATES, F. and ZACOPANAY, I. The estima. tion of the efficiency of sampling, with special reference to sampling for yield in cereal experiments, 1935, 25, 545

YATES, F., see also BlATR, G. W. S. and EDEN, T.

Zacopanay, I., see Yates, F.

ZIEMIECKA, J. The Azotobacter test of soil fertility applied to the classical fields at Rothansted, 1932, 22, 797 


\section{INDEX TO SUBJECTS}

Accessory food factors, see Vitamins A cetone by-products, see Clostridium

Acetonuria and ketonuria, alimentary, in dairy cattle induced by feeding grass silage of the butyric acid type (Brouwer and Dijkstra), 1938, 28, 695

Acid(s)bese equilibrium and reproductive activity in pullets (Common), 1941, 31, 281

fatty, see Fatty acids

sulphuric, see Sulphuric acid

Agar media for counting soil microorganisms, a comparison (Jensen), $1931,21,832$

Age conversion factors, practical applica. tion of, to dairy cattle production (butterfat) records (Ward and Campbell), 1938, 28, 509

of cows and bulls in six breeds of cattle (Smith and Robison), 1931, 21, 136

of seed beans (Garner and Sanders), $1935,25,361$

Alfalfa, seed-setting in, factors influencing (Armstrong and White), 1935, 25, 161 see also Lucerne

Alimentary acetonuria and ketonuria in dairy cattle induced by feeding grass silage of the butyric acid type (Brouwer and Dijkstra), 1938, 28, 695

Alizarin adsorption by alumina (Hardy), $1931,21,151$

identification and approximate estimation of sesquioxide components by adsorption of (Hardy), 1931, 21, 150

Alkali, extraction of the organic nitrogen of the soil with (Hobson and Page), $1932,22,297$

Alkaline soils, see Soils

Allometric growth of the forelimb in cattle (Pontecorvo), 1939, 29, 111

Alumina, alizarin adsorption by (Hardy), $1931,21,151$

Ammonia and nitrate contents of soils cropped for wheat, effects of summer green manures on (Mirchandani), 1931, 21,458

Ammonium nitrogen and nitrate nitrogen, effects of, on the growth of perennial rye grass (Lewis), 1936, 26, 249

sulphate, character of barley grown on soil made acid with (Mann), 1937, 27, 108

sulphate, effect of time of application of, to wheat (Garner and Sanders), 1936, 26,316
Ammonium sulphate, growth of clover in the presence of (Caldwell and Richardson), 1936, 26, 263

sulphate, influence on yield and composition of a single heary dressing compared with periodic small dressings (Woodman, Evans and Oosthuizen), $1938,28,598$

sulphate, residual effects of the intensive use of, on pastures (Woodman and Evans), 1938, 28, 592

sulphate, studies of soil after fifty years of wheat or barley cropping, especially soil made acid with (Mann and Barnes), 1940, 30, 345

sulphite, effect of, on plant growth (Lewis and Marmoy), 1933, 23, I

Anaerobic microflora, obligate of farmyard manure (Glathe and Cunningham), 1933, 23, 541

Analysis of groups of experiments (Yates and Cochran), 1938, 28, 556

of variance, see Statistics

Animal breeding, see specific animals

experimentation, value of the Latin square lay-out in (Garner and Sanders), $1938,28,543$

husbandry, statistical basis of selection in (Olbrycht), 1943, 33, 28, 74

nutrition, carotene in relation to, studies on (Seshan and Sen), 1942, 32, 194, $202,275,286$

nutrition, methods of experimentation in (Dunlop), 1933, 23, 580; 1934, 24, 335

nutrition experiments, control of variation in gain in (Dunlop), 1935, 25, 151

Antigen for the rapid whole blood test for bacillary white diarrhœa of chicks, preparation of a sensitive and diagnostic stained (Mann), 1945, 35, 232

Aphis rumicis, toxicity of pyrethrum to (Martin and Tattersfield), 1931, 21, 122

Appetite of sheep, measurement of (Woodman, Evans and Eden), 1937, 27, 191

stimulating factor, effect of, on the liveweight increase of swine (Dunlop), $1935,25,445$

Artificial insemination of cattle (Anderson), 1941, 31, 348

of sheep (Anderson), 1937, 27, 142; 1941, 31, 354

treatment of spermatozoa in vitro with special reference to (Chang), 1943, 33, 67 
Avtaminosis-A and paralysis in swine (Dunlop), 1934, 24, 435

Azotobacter in Malayan solls, studies on (Altson), 1936, 26, 268

test of soll fertility applied to the classical fields at Rothamsted (Z1emıęcka), 1932, 22, 797

Bacullary whte diarrhcea, see Diarrhœa Bacillus mycordes, relations of, with ammonification, nitrification and soll fertility (Tyagny-Ryadno), 1933, 23, 335

Bacullus pullorum, see Diarrhœea.

Bacon, see Pig

Bacteria, cellulose-splitting, action of, on the fibre of certain feeding stuffs (Woodman and Stewart), 1932, 22, 527

clover nodule, efficiency of different strains of (Vurtanen and von Hausen), $1935,25,290$

root-nodule, of leguminous plants, investigations on (Vurtanen and von Hausen), 1935, 25, 278, 290, 1936, 26, 281, (Virtanen, von Hausen and Laine), 1937, 27, 332, 584, (Vartiovaara), $1937,27,626$

root-nodule organisms, growth of, and inoculated peas at low temperatures (Vartiovaara), 1937, 27, 626

rumen, behaviour of, and their bearung on the problem of the nutritive value of cellulose (Woodman and Evans), 1938, 28,43

Bacterial and chemical changes, effect of the addition of various materials and bacterial cultures to grass slage at the time of making on subsequent (Allen, Watson and Ferguson), 1937, 27, 294 cultures, effect of the addition of various materals and, to grass sulage at the time of making on the subsequent bacteriological and chemical changes (Allen, Watson and Ferguson), 1937, 27, 294

syndrome arising from a diet whuch is conducive to six-day disease (Mann), $1945,35,98$

syndrome encountered in epidemic bacllary white diarrhoea of chicks ( $P$ ul lorum disease) (Mann), 1945, 35, 214

Bacteriological and chemical changes occurring in grass sllage, study of (Allen, Harrison, Watson and Ferguson), 1937, 27, 271

Baking quality, critical survey of breed Ing wheat for (Frankel), 1940, 30, 98

of English wheat, influence of manurial treatment on (Fisher and Jones), 1931, 21, 574

Barley, carotene and protein in, at different stages of growth (Smith and Robb), 1943, 33, 119
Barley, character of, grown on sol made acıd with sulphate of ammonia (Mann), $1937,27,108$

cropping in acid solls, fifty years of (Mann and Barnes), 1940, 30, 345

date of ear emergence in (Bell), 1939, 29, 175

effect of low-temperature grain pretreatment on the development, yield and grain of some varieties of (Bell), $1937,27,377$

grain, factors influencing the percentage of nitrogen in (Yates and Watson), $1939,29,452$

nitrogen content of certain varieties of relation of ear survival to (Hunter and Hartley), 1938, 28, 472

photosynthesis in the ear of, and the movement of nitrogen into the ear (Watson and Norman), 1939, 29, 321

plant, development of structural constituents in (Norman), 1933, 23, 216

rachulla length in, inheritance of (Bell and Carson), 1941, 31, 246

straw for horses, effect of Beckmann's treatment by sodium hydroxide on the digestibility and feeding value of (Willamson), 1941, 31, 488

stripe diseases of (Weston and Taylor), $1943,33,23$

winter hardy, breeding of two-row (Bell), 1944, 34, 223

yield of, on very exhausted land, in. fluence of fallowng on (Mann), 1943, 33, 207

Base exchange in solls, see Sols

Bean(s), broad-bean-pod meal, composıtion and nutritive value of, when fed to ruminants (Woodman and Evans), $1940,30,189$

field, effect of borax dressungs on the growth and yield of (Owen, Snow and Thom), 1945, 35, 119

seed, on the age of (Garner and Sanders), $1935,25,361$

Beef, see Meat

Bentonite, see Calcium bentonite

Blochemistry of water logged sols (Sreenivasan and Subrahmanyan), $1935,25,6$

Biscult waste for pigs, war-time rations (Braude and Foot), 1942, 32, 70

Blood copper of Northumberland sheep (Eden), 1941, 31, 186

test, rapid whole, for bacillary white diarrhoea of chicks, preparation of a sensitive and diagnostic stained antigen for (Mann), 1945, 35, 232

see also Haemoglobin

Body fat in rabbits, effect of 'condition' on the colour of (Hurzel), 1935, 25, 541 
Body fat of the fowl, effect of different cereals in the fattening ration on the composition of (Cruickshank), 1937, 27, 309

proportions of different breeds of bacon pigs (Hammond and Murray), 1937, 27, 394

temperature measurements of pigs (Deighton), 1935, 25, 180

Borax, effect of, on the growth and yield of field beans (Vicia faba L.) (Owen, Snow and Thom), 1945, 35, 119

Bracken, chemical composition of (Ferguson and Armitage), 1944, 34, 165

ensilage (Ferguson and Neave), 1944, 34, 172

Bran, see Wheat offals

Breeding, animal, see Artificial insemination, Fertility, etc. and specific animals

plant, see specific plants

Broad-bean, see Bean

Bull(s), age of, in six breeds of cattle (Smith and Robison), 1931, 21, 136

fertility, effect of method of management at mating on (Laing), 1945, 35, 25

fertility in, characteristics of the semen in relation to (Laing), 1945, 35, I

progeny test as a method of evaluating the dairy sire (Edwards), 1932, 22, 811

reproductive capacity of, seasonal variation in (Anderson), 1945, 35, 184

semen, change in the $p \mathrm{H}$ of, after incubation (Anderson), 1944, 34, 69

semen, exchange of, between England and Holland (Edwards and Walton), 1938, 28, 503

semen, hydrogen-ion concentration of (Anderson), 1942, 32, 298

semen, rapid method of standardization of the density of (Kyaw), 1944, 34, 106

Cacao leaves, decomposition of, under natural conditions (Humphries and Rodriguez), 1945, 35, 247

Calcium and phosphate, effect of, on growth and productivity of the cultivated mushroom (Pizer and Thompson), 1938, 28, 604

and phosphorus balances with laying birds (Tyler and Willoox), 1942, 32, 43

and phosphorus combination in the excrets of the non-laying pullet, nature of (Knowles, Watkin and Hendry), 1933, 23, 196

and phosphorus, relation of, to growth and rachitic leg weakness in chickens (Parkhurst and McMurray), 1932, 22, 874

and the interfacial tension of pyrethrum extracts (Hobson), 1931, 21, 101
Calcium bentonite and sand as the growth medium in potculture (Greenhill and Page), 1933, 23, 329

body, mobilization of, for shell formation (Common and Hale), 1941, 31, 415

cyanamide, decomposition of, in the soil, and its effects on germination, nitrification and soil reaction (Crowther and Richardson), 1932, 22, 300

cyanamide, microbiological aspects of nitrification in soils under varied environmental conditions (Mukerji), $1932,22,335$

cyanamide, storage and mixing with superphosphate (Richardson), 1932, 22, 348

cyanamide, studies on (Crowther and Richardson), 1932, 22, 300; (Mukerji), 1932, 22, 335; (Richardson), 1932, 22 , 348; 1934, 24, 491; (Richardson and Crowther), 1935, 25, 132

cyanamide, use of, and other forms of nitrogen on grassland (Richardson), $1934,24,491$

cyanamide, utilization of, in pot culture experiments (Richardson and Crow. ther), 1935, 25, 132

dietary, influence of different levels of, upon porosity of egg shells (Tyler), $1945,35,168$

deficient ration, sheep fed on, effect of lime and cod-liver oil on (Auchinachie and Fraser), 1932, 22, 560

phosphorus and vitamin $D$ requirement of swine (Dunlop), 1935, 25, 22

requirement of the laying bird (Common), $1943,33,213$

requirements of poultry with particular reference to their needs for main. tenance ('Tyler and Willcox), 1942, 32,62

status of soil, effect of nitrogenous fertilizers on (Lewis), 1938, 28, 197

Calluna vulgaris, see Heather

Calorimeter for the direct determination of the metabolism of fowls (Deighton), $1939,29,431$

Carbohydrate(s) reserves in red clover roots, effect of cutting on (Virtanen and Nurmia), 1936, 26, 288

roughage, chemical nature and digestibility of (Bondiand Meyer), 1943,33, 123

Carbon and nitrogen cycles in soil (Du Toit and Page), 1932, 22, 115; (Hobson and Page), 1932, 22, 297, 497, 516; (Page), 1932, 22, 291

and nitrogen transformations in water. logged soils (Sreenivasan and Subrah. manyan), 1935, 25, 6

dioxide, diffusion of, through porous solids (Penman), 1940, 30, 570

in soils, accurate wet-combustion method for the determination of (Alper), 1938 28,$187 ; 1942,32,389$ 
Carbon, organic, see Organic carbon

Carbonic anhydrase activity of the hen's oviduct (Common), 1941, 31, 412

Carcass(es) characters of Danish and English bacon pigs, nature and variability of (McMeekan), 1939, 29, 131

investigations with rabbits (Dudley and Wilson), 1943, 33, 129

measurements as indices of the composition of the bacon pig (McMeekan), $1941,31,1$

quality and growth rate in bacon pigs. A study of polynomial coefficients fitted to growth rate data (Donald), 1940, 30, 582

quality characters, growth and development in the pig, with special reference to (McMeekan), 1940, 30, 276, 387, $511 ; 1941,31,1$

quality, fats of the bacon pig with reference to (Shorland and $\mathrm{De} \mathrm{La}$ Mare), 1945, 35, 33, 39

quality, influence on, of including meat meals of widely differing fat content in the rations of bacon pigs (Woodman and Evans), 1939, 29, 502

quality, minimum level of protein intake consistent with quick grow th and, of the bacon pig (Woodman, Callow, Evans, and Turpitt), 1939, 29, 115; 1940, 30, $83 ; 1941,31,232 ; 1945,35,133$

rabbit, composition of (Wilson and Morris), 1932, 22, 453

Carobs, digestibility of (Bondi and Meyer), 1944, 34, 118

Carotene balance experiments with cows and bullocks (Seshan and Sen), 1942, 32, 286

content of certain species of grassland herbage (Smith and Wang), 1941, 31, 370

content of poor pasture grass, influence of manurial treatment on, and on the relationship of this constituent to the ash and organic fractions (Moon), 1939, 29,524

development and distribution of, in the plant and the carotene content of some feeding stuffs (Seshan and Sen), 1942, 32, 202

estimation in feeding stuffs, technique of (Seshan and Sen), 1942, 32, 194

from grass, quantitative extraction of (Moon), 1939, 29, 295

in artificially dried grass and hays, factors affecting the stability and estimation of (Kon and Thompson), 1940, 30, 622

in oats and barley at different stages of growth (Smith and Robb), 1943, 33, 119

in relation to animal nutrition, studies on (Seshan and Sen), 1942, 32, 194, 202, 275,286
Carotene metabolism, effect of diet on (Mann), 1945, 35, 101

stability of, in plant material with special reference to hay making and storage (Seshan and Sen), 1942, 32, 275

Carrot, nutrition of the (Woodman and Paver), 1945, 35, 30

response of, to water supply and fertilizer on a gravel soil (Woodman and Johnson), 1944, 34, 82

Castration of lambs, effects of different methods of, on growth (Garner and Sanders), 1936, 26, 296

Catalyst, selenium as a, in the Kjeldahl method as applied to soil and grass analysis (Ashton), 1936, 26, 239

Cattle, ages of cows and bulls in six breeds of cattle (Smith and Robison), 1931,21,136 allometric growth of the forelimb in (Pontecorvo), 1939, 29, 111

artificial insemination of (Anderson), $1941,31,348$

behaviour and grazing habits of, grazing management practices and their relationship to (Johnstone-Wallace and Kennedy), 1944, 34, 190

breeding, pedigree, herd size and its genetical significance in (Donald and El Itriby), 1945, 35, 84

carotene balance experiments with (Seshan and Sen), 1942, 32, 286

comparative digestive powers of zebu and high-grade European cattle (French), $1940,30,503$

dairy, alimentary acetonuria and ketonuria in, induced by feeding grass silage of the butyric acid type (Brouwer and Dijkstra), 1938, 28, 695

dairy, influence of environmental temperature on the respiratory rhythm of, in the tropics (Rhoad), 1936, 26, 36

dairy, production (butter-fat) records, practical application of age conversion factors to (Ward and Campbell), 1938 , 28, 509

dairy, sterility in, use of chorionic gonadotrophin (pregnancy urine extract) for the treatment of (Bottomley, Folley and Watson), 1940, 30, 235

effect of method of management at mating on bovine fertility (Laing), $1945,35,25$

embryonic growth in, periods of (Kis. lovsky and Larchin), 1931, 21, 659

fat-soluble vitamin requirements of during growth (Isaachsen), 1932, 22,460

food value of beef from steers and heifers, and its relation to dressing-out percentage (Callow), 1944, 34, 177

oestrus in zebu and grade cattle, period. icity and duration of (Anderson), 1944, 34,57

see also Bulls, Cows, Heifers, etc. 
Cellulose digestion in the ruminant organism, mechanism of (Woodman and Stewart), 1932, 22, 527, (Woodman and Evans), 1938, 28, 43

in farmyard manure, decomposition of (Jensen), 1931, 21, 81

nutntive value of, behaviour of rumen bacteria and their bearing on (Wood man and Evans), 1938, 28, 43

-splitting bacteria, action of, on the fibre of certain typical feeding stuffs (Woodman and Stewart), 1932, 22, 527

Census studres on yield in cereals Victoria (Forster and Vasey), 1931, 21, 372

Cereal(s) breeding technique, yield characters of selected oat varieties (Stephens), 1942, 32, 217

crops and annual weeds, nature of the competition between (Blackman and Templeman), 1938, 28, 247

crops, ergot in, observations on (Weston and Taylor), 1942, 32, 457

effect of different, in the fattening ration on the composition of the body fat of the fowl (Cruickshank), 1937, 27, 309

eradication of weeds in, by sulphuric acid and other compounds (Blackman and Templeman), 1936, 26, 368

experiments, estimation of efficiency of sampling, with special reference to sampling for yield in (Yates and Zacopanay), 1935, 25, 545

experiments, estimation of the yields of, by sampling for the ratio of grain to total produce (Cochran), 1940, 30, 262

experiments, small scale threshing and winnowing machine for (Simpson), $1931,21,372$

experiments, studies in sampling tech nıque (Clapham), 1931, 21, 366, 376, (Simpson), 1931, 21, 372

feeding stuffs, manufacture and storage of, with incorporated non protein nitrogen compounds (Snow, Smith and Wright), 1945, 35, 65

lodging in, some factors influencing (Brady), 1934, 24, 209

placement of fertilizers (Lewis and Strickland), 1944, 34, 73

susceptibility of, to manganese deficiency (Gallagher and Walsh), 1943, 33, 197

yield in, investigations on (Engledow and Pal), 1934, 24, 390

yreld in, investigations on Victoria (Forster and Vasey), 1931, 21, 391

yield of, influence of rainfall on, in relatron to manurial treatment (Cochran), $1935,25,510$

Chemical and bacterial changes, effect of addition of various matenals and bacterial cultures to grass slage at time of makung on subsequent (Allen, Watson and Ferguson), 1937, 27, 294
Chemical and bacteriological changes occurring in grass silage, study of (Allen, Harmson, Watson and Ferguson), 1937, 27, 271

Chuckens, see Poultry

Chorionic gonadotrophun, use of, for the treatment of sterility in dairy cattle (Bottomley, Folley and Watson), 1940, 30, 235

Chrysanthemum cineranaefolium, see Pyrethrum

Clay (s) and organic matter, contribution of, to the base exchange capacity of sols (Willams), 1932, 22, 845

chemical analysis of, with special refer ence to clay fractions of solls (Groves), $1933,23,519$

cohesion and viscosity of (Richardson), $1933,23,176$

fraction, subdivision of, in mechanical analysis (Russell), 1943, 33, 147

fractions of a black cotton sol and a red earth from Hyderabad, India, minerals in (Nagelschmidt, Desal and Mur), $1940,30,639$

permeablity of saturated sands, solls and clays (Carman), 1939, 29, 262

red sandy, movement of potassium in irrigated and fertuluzed (Lachower), $1940,30,498$

sols, heavy, transport of water through (Childs), 1936, 26, 114, 527, (Nıcholson and Childs), 1936, 26, 128

suspensions, theory of the coagulation of (Russell), 1932, 22, 165

Clumate, effect of climatic variations on the plasticity of soll (Blair and Yates), $1932,22,639$

Clostridium residue, dried, pig feedıng experiment using (Braude and Foot), $1942,32,324$

Clover, growth of, in the presence of ammonium sulphate (Caldwell and Richardson), 1936, 26, 263

nodule bacteria, efficiency of different strains of (Vurtanen and von Hausen), $1935,25,290$

red, effect of cuttung on the carbohydrate reserves in roots (Virtanen and Nurmia), 1936, 26, 288

red, inclusion of, in four year leys (Garner and Sanders), 1939, 29, 164

sickness, investigations on (Mann), 1938, 28,437

winter hardiness of, studies on (Vurtanen and Nurma), 1936, 26, 288

Coal, fertuluzing value and nitrifiability of humic materials prepared from (Crowther and Brenchley), 1934, 24, 156

Cockerel, see Poultry

Cod-liver oll, effect of, on sheep fed on a calcium deficient ration (Auchunachie and Fraser), 1932, 22, 560 
Cod-liver oil, pig-feeding experiments with (Foot, Henry, Kon and Mackintosh), 1939, 29, 142

relative values of genuine and a sample of controlled, in feeding poultry up to 16 weeks (Wright), 1941, 31, 161

Colloids, soil, see Soil

Colostrum of dairy cows, vitamin A content of (Stewart and McCallum), $1938,28,428$

Colour of body fat in rabbits, effect of 'condition' on (Hirzel), 1935, 25, 541

soil, note on a method for the preparation of permanent records of (Whittles), 1931, 21, 189

Combustion, wet-, method for the determination of carbon in soils (Alper), 1938, 28, 187

Competition between cereal crops and annual weeds, nature of (Blackman and Templeman), 1938, 28, 247

Compost(s) heaps, changes occurring in the organic matter during the decomposition of (Ashworth), 1942, 32, 360

in relation to the growth of mushroom mycelium, some properties of (Pizer), $1937,27,349$

organic transformations in (Duthie), $1937,27,162$

Compressibility curves as a quantitative measure of soil tilth (Blair), 1937, 27, 541; (Blair and Cashen), 1938, 28, 367

Confounding, see Statistics

Copper, blood, of Northumberland sheep, further observations on (Eden), 1941, 31, 186

deficiency in plants, investigations on (Piper), 1942, 32, 143

excretion of, in the rabbit, studies on (Eden), 1941, 31, 145

in the diet of fattening pigs, some observations on the need for (Braude), $1945,35,163$

in the Karaka tree, distribution of (Pitcaithby and Worley), 1933, 23, 204 sulphate, see Sulphate

Corn, seed, large-scale field trials on the disinfection of, with mercury dust disinfectants (Weston, Hanley and Booer), 1937, 27, 43

Corynocarpus laevigata, see Karaka tree

Cotton, design of plots for variety trials (MacDonald, Fielding and Ruston), $1939,29,35$

effects of seed rate and time of thinning on the development and yield of cotton plants in hand-planted cotton trials (MacDonald, Fielding and Ruston), $1939,29,418$

experimental methods with (MacDonald, Fielding and Ruston), 1939, 29, 35, 418

intervarietal competition in yield trials with (Christidis), 1935, 25, 231
Cotton, production of, under irrigation in the Sudan, interrelation of factors controlling (Gregory, Crowther and Lambert), 1932, 22, 617

rain-grown, effects of varying soil consolidation on growth and development of (Heath), 1937, 27, 511

rotation experiments with, in the Sudan Gezira (Crowther and Cochran), 1942, 32, 390

-seed treatment with sulphuric acid (Christidis), 1936, 26, 648

Covariance, see Statistics

Cow(s), age of, in six breeds of cattle (Smith and Robison), 1931, 21, 136

carotene balance experiments with (Seshan and Sen), 1942, 32, 286

conformation of, as related to milk secretion (Gowen), 1933, 23, 485

conformation of the parents as related to the milk secretion of the daughters (Gowen), 1933, 23, 514

dairy, effect of feeding oils to (Garner and Sanders), 1938, 28, 543

dairy, nutrient intake and milk production of, effect of war-time changes in the food supply on (Blaxter), 1944, 34, 22

dairy, nutrition experiments, an examination of the value of covariance in (Bartlett), 1935, 25, 238

dairy, value of artificially dried grass, silage made with added molasses and A.I.V. fodder in the diet of, and their effect on the quality of the milk (Watson and Ferguson), 1936, 26, 337

dairy, vitamin A content of colostrum of (Stewart and McCallum), 1938, 28, 428

dairy, wastage, length of productive life, replacement and depreciation of (Pettit), 1940, 30, 485

haemoglobin level of (Allcroft), 1941, 31, 320

ovulation in, control of (Hammond and Bhattacharya), 1944, 34, 1

survival time of the spermatozor in the genital tract of, and its relation to fertility, observations on (Laing), $1945,35,72$

see also Heifers, Milk

Crop(s), agricultural, empirical law describing heterogeneity in the yields of (Smith), 1938, 28, I

cereal, and annual weeds, nature of competition between (Blackman and Templeman), 1938, 28, 247

field, estimation of leaf area in (Watson), $1937,27,475$

germination interval of, influence of soil temperature on (Irwin), 1931, 21, 241

growth, influence of seed bed on (Russell and Mehta), 1938, 28, 272 
Crop(s) husbandry, investigations in (Garner and Sanders), 1932, 22, 551, $1935,25,361,1936,26,316,415$

magnesium deficiency in some, in relation to the level of potassium nutrition (Walsh and O'Donohoe), 1945, 35, 254 mixed, not receiving nitrogenous manure, investigation of nitrogen uptake in (Nowotnówna), 1937, 27, 503

relation between cultivation implements, soll structure and (Culpın), 1936, 26, $22,45,1937,27,432$

resıdues, see Manures

-weather scheme, an exammation of the sampling observations on wheat (Barnard), 1936, 26, 456

yseld, effect of cultivation on (Russell and Keen), 1938, 28, 212

yreld, effect of the 'Gyrotiller' on (Garner and Sanders), 1938, 28, 401

Cropping in acid solls, fifty years of wheat or barley (Mann and Barnes), 1940, 30, 345

Cultivation, effect of inter tillage on the sugar beet crop (Russell, Keen and Mann), 1942, 32, 330

implements, soll structure and the crop, relation between (Culpin), 1936, 26, $22,45,1937,27,432$

soll, see Soll

spring, of autumn sown wheat (Garner and Sanders), 1937, 27, 447

Cuticle, function of, in relation to porosity of eggs (Marshall and Cruckshank), $1938,28,24$

Cuttung at monthly intervals, influence of, on the quality and productivity of a heavy land pasture (Woodman and Evans), 1938, 28, 581

effect of, on the carbohydrate reserves of red clover roots (Vurtanen and Nurmia), $1936,26,288$

systematic, influence of, at three stages of growth on the yield, composition and nutritive value of lucerne (Woodman, Evans and Norman), 1934, 24, 283

time of, influence on growth, yneld and composition of tropical fodder grasses (Paterson), 1933, 23, 615

Cyanamide, calcium, see Calcium

Cystem, effect of administration of, on the growth of wool of a Mermo ewe on a protesn-poor ration (Marston), 1935, 25, 113

Cystune content of pasture grass (Evans), 1931, 21, 806

effect of adminustration of, on the growth of wool of a Merno ewe on a protem poor ration (Marston), 1935, 25, 113

Decay, rate of, in relation to soll types and vegetative covering in Glamorgan (Isaac), 1933, 23, 31
Decomposition of cacao leaves under natural conditions (Humphries and Rodriguez), 1945, 35, 247

Diarrhœa, epidemic bacillary white, of chicks, bacterial syndrome encountered in (Mann), 1945, 35, 214

epidemic bacillary white, of chicks, control of (Mann), 1945, 35, 225

epidemic bacillary white, of chicks, in fluence of diet on (Mann), 1945, 35, 207 epidemic bacillary white, of chicks, pre. paration of a sensitive and diagnostic stamed antigen for the rapid whole blood test for (Mann), 1945, 35, 232

Diet, bacterial syndrome arising from, which is conducive to six day disease in chucks (Mann), 1945, 35, 98

effect of, on mortality, with special reference to six day disease in chicks (Mann), 1945, 35, 95

effect of, on the component fatty acids of the back fat of bacon pigs (Shorland and De La Mare), $1945,35,33$

effect of, on vitamin A, xanthophyll and carotene metabolism in chicks (Mann), $1945,35,101$

of fattening pigs, some observations on the need for copper in (Braude), 1945, 35, 163

Dietary calcium, influence of different levels of, upon porosity of egg shella (Tyler), 1945, 35, 168

Differential regression, see Statistics

Digestubility and feeding value of barley straw for horses, effect of Beckmann's treatment by sodium hydroxide on (Willamson), 1941, 31, 488

and nutritive value of different types of swill (Woodman and Evans), 1942,32, 85 and nutritive value of samples of grass land products (Watson and Horton), $1936,26,142$

of artificially dried grass (Watson), 1931, 21, 414, 425, (Watson and Ferguson), $1932,22,235$

of dreg meal (Watson), 1931, 21, 410

of dried molassed sugar beet pulp (Halnan), 1937, 27, 137

of dura, carobs and hide-fleshings (Bond and Meyer), 1944, 34, 118

of grass slage made in a pit (Watson), $1931,21,469$

of grass sllage made in a stack (Watson), $1931,21,452$

of grass sllage made in a tower (Watson), $1931,21,425$

of grassland herbage, effect of nitrogen on (Watson, Procter and Ferguson), 1932, 22, 257

of Northern Irish rye-grass seed and ryegrass seed cleanings (Common), 1945, 35, 56, (Rutledge and Common), 1945, 35,123 
Digestibility of potato cossettes and potato meal when fed to pigs and sheep (Woodman and Evans), 1939, 29, 347

of roughage carbohydrates, chemical nature and (Bondi and Meyer), 1943, 33,123

of straw pulp (Ferguson), 1943, 33, 174

of sunflower seeds (Halnan), 1943, 33, 113

of three grades of meat meal of widely differing fat content, when fed to pigs (Woodman and Evans), 1937, 27, 465

of wheaten offals, influence of war-time milling control on (Woodman and Evans), 1944, 34, 35

of wheat offals (Hainan), 1937, 27, 126

trials with poultry (Halnan), 1937, 27, 126,$137 ; 1943,33,113 ; 1944,34,133$, 139; (Bondi and Meyer), 1944, 34, 118

Digestion, cellulose, mechanism of, in the ruminant organism (Woodman and Stewart), 1932, 22, 527; (Woodman and Evans), 1938, 28, 43

of huskless oats by poultry (Moon and Thomas), 1937, 27, 458

Digestive powers, comparative, of zebu and high-grade European cattle (French), 1940, 30, 503

Disinfection, seed, see Seed

Docking of lambs, effects of different methods of, on growth (Garner and Sanders), 1936, 26, 296

Drain(s), field, rates of flow from outfalls (Nicholson), 1934, 24, 349

field, róle of, in removing excess water from the soil (Nicholson), 1934, 24, 349

gauges, percolation through, effect of rainfall and temperature on (Koshal), $1934,24,105$

mole, durability of (Nicholson), 1934, 24, 185

Drainage and evaporation from fallow soil at Rothamsted (Penman and Schofield), 1941, 31, 74

mole-, interim report on an experimental drainage field (Childs), 1943, 33, 136

mole-, studies in (Childs), 1943, 33, 136

relation of, to rainfall and other meteorological factors (Sahni), 1941, 31, 110

soil, scientific research in (Russell), 1934, 24,544

Dreg meal, digestibility and feeding value of (Watson), 1931, 21, 410

Drought, effect on mineral content of pasture (Ferguson) 1931, 21, 233

Dry matter in mangels, estimation of (Elphick and McMahon), 1935, 25, 1

loss of, from stored bran, respiration rate and (Snow and Wright), 1945, 35, 126

Dura, digestibility of (Bondi and Meyer), $1944,34,118$
Dusts, disinfectant, containing mercury, outline of an investigation on (Weston and Booer), 1935, 25, 628

disinfectant, containing mercury, seed protection by the use of (Brett, Weston and Booer), 1937, 27, 53

disinfectants, large-scale field trials on the disinfection of seed corn with mercury (Weston, Hanley and Booer), 1937, 27, 43

Dye adsorption, see Alizarin

Ear of barley, photosynthesis in, and the movement of nitrogen into the ear (Watson and Norman), 1939, 29, 321

survival, relation of, to the nitrogen content of barley (Hunter and Hartley). $1938,28,472$

$\mathrm{Egg}(\mathrm{s})$, porosity of, function of the cuticle in relation to (Marshall and Cruickshank), 1938, 28, 24

production, dried potato products for: statistical analysis of a laying experiment (Bolton and Hale), 1945, 35, 158

production, factors modifying, with special reference to seasonal changes (Whetham), 1933, 23, 383

shells, porosity of, and the influence of different levels of dietary calcium upon porosity (Tyler), 1945, 35, 168

turkeys, influence of incubation temperature on the hatchability of (Romanoff), $1935,25,318$

Electric oven for drying samples from field plots (Garner, Grantham and Sanders), $1935,25,315$

Electrical capacity and conductivity of soil blocks, measurements of (Cashen), $1932,22,145$

conductivity of aqueous soil suspensions, measurement of (Sen), 1932, 22, 212

conductivity of aqueous soil suspensions as a measure of fertility (Sen and Wright), 1931, 21, 1

Electrode, glass, use of, in soil reaction and oxidation-reduction potential measurements (Heintze), 1934, 24, 28

potentials in laboratory silage (Common and Bolton), 1942, 32, 338

Electrodialysis apparatus for the deter. mination of replaceable bases in soils (Basu) , 1931, 21, 484

Elephant grass, see Grass

Embryonic growth, see Growth

Empirical law describing heterogeneity in the yields of agricultural crops (Smith), 1938,28 , 1

Energy, metabolizable, of sunflower seeds (Hainan), 1943, 33, 113

net, of Sussex ground oats and white maize meal for fattening cockerels, determination of the comparative (Deighton and Hutchinson), 1940, 30, 463 
Ensilage, bracken (Ferguson and Neave), $1944,34,172$

Ergot in cereal crops, observations on (Weston and Taylor), 1942, 32, 457

Evaporation and drainage from fallow soil at Rothamsted (Penman and Schofield), 1941, 31, 74

from fallow soil, laboratory experiments on (Penman), 1941, 31, 454

Ewe, ovulation in the (Anderson), 1938, 28,64

Exchangeable bases in soils, see Soils

Excreta and fodder, estimation of the sulphur content of (Marston), 1938, 28, 679

of the non-laying pullet, nature of the calcium and phosphorus combination in (Knowles, Watkin and Hendry), $1933,23,196$

Experimental error and field-plot technique with potatoes (Kalamkar), 1932, 22, 373

in chicken-rearing experiments (Hale), $1931,21,716$

in field experiments, influence of system. atic plot arrangement upon the esti. mate of (Tedin), 1931, 21, 191

of field experiments with tea (Eden), $1931,21,547$

Experimentation in animal nutrition, methods of (Dunlop), 1933, 23, 580; $1934,24,335$

Experiments, analysis of groups of (Yates and Cochran), 1938, 28, 556

field, see Field experiments

replicated, principles of orthogonality and confounding in (Yates), 1933, 23, 108

Fallopian tube of the mare, ovulation and the descent of the ovum in, after treat. ment with gonadotrophic hormones (Day), 1939, 29, 459

Fallowing, influence of, on the yield of wheat or barley on very exhausted land (Mann), 1943, 33, 207

Farmyard manure, see Manure

Fasting metabolism of various breeds of hog (Deighton), 1934, 24, 326; 1935, 25,$180 ; 1937,27,317$

Fat(s), back, effect of diet on the component fatty acids of (Shorland and De La Mare), 1945, 35, 33

body, in rabbits, effect of 'condition' on the colour of (Hirzel), 1935, 25, 541

body, of the fowl, effect of different cereals in the fattening ration on the composition of (Cruickshank), 1937, 27, 309

depot, of the bacon pig, relation between growth rate and chemical composition of (Shorland and De La Mare), 1945, 35, 39

of the bacon pig with reference to carcass quality (Shorland and De La Mare), 1945, 35, 39
Fat(s) of three grades of meat meal of widely differing fat content, composition and digestibility when fed to pigs (Woodman and Evans), 1937, 27, 465

-soluble vitamin requirements of cattle and pigs during growth (Isaachsen), $1932,22,460$

Fatty acids of the back fat of bacon pigs, effect of diet on the component (Shorland and De La Mare), 1945, 35, 33

Fecundity in the domestic fowl: behaviour of persistency in individual hens (Greenwood, Blyth and Galpin), 1940, 30, 202

of male rabbits as determined by 'dummy matings' (Macirone and Walton), 1938, 28, 122

Feeding bulky foods, methods of (Blaxter and French), 1944, 34, 217

influence of changes in level of, on milk production (Yates, Boyd and Pettit), $1942,32,428$

Feeding stuffs, biscuit meal, see Biscuit meal

bracken, see Bracken

bran, see Wheat offals

broad-bean-pod meal, see Bean

bulky foods, methods of feeding (Blaxter and French), 1944, 34, 217

carobs, see Carobs

carotene content of some common (Seshan and Sen), 1942, 32, 202

carotene estimation in, technique of (Seshan and Sen), 1942, 32, 194 cereals, see Cereals

Clostridium residue, see Clostridium cod-liver oil, see Cod-liver oil

determination of total sulphur and sulphate sulphur in (Woodman and Evans), 1933, 23, 459

dreg meal, see Dreg meal

dried skim milk, see Milk

dura, see Dura

fibre of, action of cellulose-splitting bacteria on (Woodman and Stewart), $1932,22,527$

fodder yeast, see Fodder

grass, see Grass

grassland products, composition, digestibility and nutritive value of samples of (Watson and Horton), 1936, 26, 142

hay, see Hay

heather, see Heather

hide-fleshings, see Hide-fleshings

home-grown foods for milk production, experiments on the use of (Blaxter and French), 1944, 34, 22, 27, 213, 217

kale, see Kale

lawn-grass cuttings, see Grass

legume husks, see Legumes

lucerne, see Lucerne

maize meal, see Maize 
Foeding stuffis, mangolds, see Mangolds meat meals, see Meat

oats, see Oats

oils, see Oils

palm-kernel meal, see Palm-kernel

pasture, see Pasture

pea-canning by-products, see Pea

pea-pod meal, see $\mathrm{Pea}$

potato, see Potato

quality factor in (Murray), 1933, 23, 185

roughage carbohydrates, chemical nature

and digestibility of (Bondi and Meyer), $1943,33,123$

rye-grass seed, see $R$ ye-grass

sago pith meal, see Sago pith meal

silage, see Silage

straw, see Straw

sugar beet pulp, see Sugar beet

swill, see Swill

tapioca flour, see Tapioca

urea, see Urea

whale-meat, see Whale-meat

wheat offals, see Wheat offal

Fertility, bovine, effect of method of management at mating on (Laing), $1945,35,25$

in sheep, hormonal augmentation of (Hammond, Hammond and Parkes), $1942,32,308$

in the bull, characteristics of the semen in relation to (Laing), 1945, 35, 1

mortality, and growth rate in pigs (Menzies-Kitchin), 1937, 27, 611

survival time of the spermatozoa in the genital tract of the cow and its relation to (Laing), 1945, 35, 72

Fertilizer(s), borax, see Borax

effects of, on yields of crops grown in rotation (Cowie), 1945, 35, 197

influence of, on replaceable bases of a light acid soil (Crowther and Basu), $1931,21,689$

inorganic nitrogen, see Nitrogen

interactions, some effects of, on growth and composition of the potato plant (Knowles, Watkin and Cowie), 1940, 30, 159

placement of. Cereals (Lewis and Strickland), 1944, 34, 73

placement of. Root crops (Lewis), 1941, 31, 295

response of the carrot to, on a gravel soil (Woodman and Johnson), 1944, 34, 82

value of some concentrated materials, particularly urea and guanidine and their nitrates and phosphates (Lewis), $1936,26,509$

see also Manures

Fibre, crude, composition of (Norman), $1935,25,529$

of certain typical feeding stuffs, action of cellulose-splitting bacteria on (Woodman and Stewart), 1932, 22, 526
Field beans, see Beans

crops, estimation of leaf area in (Watson), 1937, 27, 475

drains, see Drains

experimental data, value of covariance in analysing (Garner, Grantham and Sanders), 1934, 24, 250

experimentation, importance of shape of plots in (Christidis), 1931, 21, 14

experimentation with rubber, value of a uniformity trial in (Murray), 1934, 24, 177

experiments, estimate of error in, influence of systematic plot arrangement upon (Tedin), 1931, 21, 191

experiments of factorial design (Wishart), 1938, 28, 299

experiments, uniformity trial with irrigated broadcast rice (Lord), 1931, 21, 178

experiments with large blocks, approximate recovery of information from replicated (Bartlett), 1938, 28, 418

experiments with potatoes, influence of size and shape of plots on the precision of (Justesen), 1932, 22, 366

experiments with tea, experimental errors of (Eden), 1931, 21, 547

-plot technique with potatoes, experi. mental error and (Kalamkar), 1932, 22, 373

plots, an electric oven for drying samples from (Garner, Grantham and Sanders). $1935,25,315$

technique in cereal experiments (Clapham), 1931, 21, 366

trials, large-scale, on the disinfection of seed corn with mercury dust disin. fectants (Weston, Hanley and Booer), $1937,27,43$

Fisher's $z$ test, validity of, when applied to an actual example of nonnormal data (Eden and Yates), 1933, 23, 6

'Flatweed', data on, with a note on inorganic constituents (Rutledge and Common), 1945, 35, 123

Flax, uptake of nutrients by (Lewis), 1943, 33, 169

Fleece, development of the characters of during growth in the different regions of the body (Thomasset), 1938, 28, 523

Flour, tapioca, see Tapioca

Fodder and excreta, estimation of the sulphur content of (Marston), 1938, 28, 679

grass, see Grass, fodder

yeast for pigs, war-time rations (Braude and Foot), 1942, 32, 70

Foetus, oestrous cycle of the mare following removal of, at various stages of pregnancy (Day), 1939, 29, 470 
Food supply, effect of war-time changes in, on the nutrient intake and milk production of dairy cows (Blaxter), 1944, 34,22

value of beef from steers and heifers, and its relation to dressing-out percentage (Callow), 1944, 34, 177

Fowl, see Poultry

Fractionation of organic matter, including nitrogen, of certain soils and its rela. tion to their quality (Ashworth), 1942, 32, 349

of the soil phosphorus, attempted (Dean), $1938,28,234$

Fungicides, fungicidal properties of certain epray-fluids (Martin and Salmon), $1931,21,638$; 1932, 22, 595; 1933, 23, 228 ; 1934, 24, 469

fungicidal properties of glyceride oils (Martin and Salmon), 1933, 23, 228

fungicidal properties of mineral, tar and vegetable oils (Martin and Salmon), $1931,21,638$

fungicidal properties of the products of hydrolysis of sulphur (Martin and Salmon), 1932, 22, 595

see also Dusts

Gas(es) and vapour movements in the soil (Penman), 1940, 30, 437, 570

combustible, that occur in the gaseous metabolic products of sheep, identification and measurement of (Lugg), 1938, 28, 688

Gaseous metabolic products of sheep, identification and measurement of the combustible gases that occur in (Lugg), 1938, 28, 688

Genital tract of the cow, survival time of the spermatozoa in, and its relation to fertility (Laing), 1945, 35, 72

of the mare, survival of spermatozon in (Day), 1942, 32, 108

of the mare, survival of stored spermatozoa in (Laing), 1943, 33, 64

Grology, soil studies in relation to, in an area in north-east Scotland (Hart), $1941,31,438 ; 1942,32,373$

Germination, effect of decomposition of calcium cyanamide in the soil on (Crowther and Richardson), 1932, 22, 300

interval of crops, influence of soil temperature on (Irwin), 1931, 21, 241

of peas, experiments on (Brett, Weston and Booer), 1937, 27, 53

of seeds and growth of seedlings, some effects of radioactive mud upon (Havas), 1935, 25, 198

of sugar beet, effects of seed treatments on (Garner and Sanders), 1932, 22, 551
Glass electrode, use of, in soil reaction and oxidation-reduction potential measurements (Heintze), 1934, 24, 28

Glyceride oils, see Oils

Gonadotrophic hormones, ovulation and the descent of the ovum in the fallopian tube of the mare after treatment with (Day), 1939, 29, 459

Grading meat: the prices given for carcasses of different weights and qualities (Hammond and Murray), 1934, 24, 233

Grain, barley, factors influencing the percentage of nitrogen in (Yates and Watson), 1939, 29, 452

behaviour in the field of small grain obtained by premature harvesting (Hatcher and Purvis), 1945, 35, 177

effect of low-temperature pre-treatment on the development, yield and grain of some varieties of wheat and barley (Bell), 1937, 27, 377

loss of vitality during storage of, treated with organo-mercury seed disinfectants (Brett and Weston), 1941, 31, 500

quality, differentiation of grain samples by means of a simple mechanical test for (Frankel), 1935, 25, 461

Grass(es), amounts of, consumed by sheep on pasturage of varying quality, determination of (Woodman, Evans and Eden), 1937, 27, 212

analysis, selenium as a catalyst in the Kjeldahl method as applied to (Ashton), 1936, 26, 239

and lucerne mixture, effect of sodium nitrate on the growth and nitrogen content of (Thornton and Nicol), 1934, 24,269

artificially dried, carotene in, factors affecting the stability and estimation of (Kon and Thompson), 1940, 30, 622

artificially dried, digestibility and feeding value of (Watson), 1931, 21, 414, 425; (Watson and Ferguson), 1932, 22, 235 artificially dried, nutritive value of, and its effect on the quality of milk (Watson and Ferguson), 1936, 26, 189 artificially dried, storage of (Wright), $1941,31,194$

artificially dried, value of, in the diet of the dairy cow, and effect on the quality of the milk (Watson and Ferguson), $1936,26,337$

elephant, influence of time of cutting on growth, yield and composition of (Paterson), 1933, 23, 615

fodder, growth, yield and composition of certain tropical (Paterson), 1935, 25, 369

fodder, influence of time of cutting on the growth, yield and composition of tropical (Paterson), 1933, 23, 615

fresh, digestibility and feeding value of (Watson and Ferguson), 1932, 22, 235 
Grass, lawn-, cuttings, value of, in the feeding of bacon pigs (Woodman and Evans), 1943, 33, 101

nitrogen uptake of, grown with lucerne (Thornton and Nicol), 1934, 24, 540

pasture, see Pasture grass

quantitative extraction of carotene from (Moon), 1939, 29, 274

sickness in horses, soil properties in rela. tion to the occurrence of (Stewart), $1941,31,308$

silage, chemical and bacteriological changes occurring in (Allen, Harrison, Watson and Ferguson), 1937, 27, 271

silage, chemical composition of (Watson and Ferguson), 1937, 27, 1

silage, comparison of the changes involved in the ordinary, molasses and A.I.V. processes (Davies, Botham and Thompson), 1937, 27, 151

silage, digestibility and feeding value of (Watson), 1931, 21, 425, 452, 469

silage, effect of the addition of various materials and bacterial cultures to, at the time of making on the subsequent bacterial and chemical changes (Allen, Watson and Ferguson), 1937, 27, 294

silage of the butyric acid type, alimentary acetonuria and ketonuria in dairy cattle induced by (Brouwer and Dijkstra), 1938, 28, 695

young, utilization of, by swine (Woodman and Norman), 1934, 24, 93

Grassland herbage, see Pasture herbage

management, intensive system of (Greenhilland Page), 1931,21, 220; (Ferguson), $1931,21,233 ; 1932,22,251$; (Watson), $1931,21,414,425,454,469$; (Watson and Ferguson), 1932, 22, 235, 247: (Watson, Procter and Ferguson), 1932, 22, 257

nitrogenous manuring of (Gardner, HunterSmith and Williams), 1931, 21, 780

permanent, response of, to nitrogen and the efficiency of its recovery (Gardner), $1939,29,364$

products, composition, digestibility and nutritive value of samples of (Watson and Horton), 1936, 26, 142

soils, nitrogen cycle in (Richardson), $1938,28,73$

soils, studies on the microbiology of (Eggleton), 1934, 24, 416

use of calcium cyanamide and other forms of nitrogen on (Richardson), $1934,24,491$

Grazing, influence of intensity of, on the yield, composition and nutritive value of pasture herbage (Woodman, Norman and French), 1931, 21, 267

management practices and their relation. ship to the behaviour and grazing habits of cattle (Johnstone-Wallace and Kennedy), 1944, 34, 190
Green manures, see Manure

Growth, allometric, of the forelimb in cattle (Pontecorvo), 1939, 29, 111

embryonic, periods of, in cattle (Kislovsky and Larchin), 193I, 21, 659

hair, see Hair

influence on, of including meat meals of widely differing fat content in the rations of bacon pigs (Woodman and Evans), 1939, 29, 502

in the bacon pig, influence of high levels of protein intake on (Woodman, Evans, Callow and Wishart), 1936, 26. 546

in the pig, influence of the plane of nutrition on (McMeekan), 1940, 30, 387,511

in the pig, with special reference to carcass quality characters (McMeekan), $1940,30,276,387,511$

of cattle and pigs, fat-soluble vitamin requirements of (Isaachsen), 1932, 22, 460

of lambs, effects of different methods of castration and docking on (Garner and Sanders), 1936, 26, 296

plant, see Plant growth

post-natal, of turkeys, influence of incubation temperature on (Romanoff), 1935, 25, 318

post-weaning, in pigs, analysis of (Smith and Donald), 1939, 29, 274

-promoting factor, effect of, on the liveweight increase of swine (Dunlop), $1935,25,445$

quick, and satisfactory carcass quality, minimum level of protein intake consistent with (Woodman, Evans, Turpitt and Callow), 1939, 29, 115; (Woodman and Evans), 1940, 30, 83; 1941, 31, $232 ; 1945,35,133$

rate and carcass quality in bacon pigs. A study of polynomial coefficients fitted to growth rate data (Donald), $1940,30,582$

rate and chemical composition of depot fat in the bacon pig, relation between (Shorland and De La Mare), 1945, 35, 39

rate, fertility and mortality in pigs (Menzies-Kitchin), 1937, 27, 611

Guamidine and urea and their nitrates and phosphates, fertilizer value of (Lewis), 1936, 26, 509

Guano, changes in composition of, during storage (Copeman and Dillman), 1937, 27, 178

Guinea-pig, hair growth and shedding in, effect of pregnancy on (Strangeways), $1933,23,379$

hair growth in, conditions and factors affecting (Strangeways), 1933, 23, 359

'Gyrotiller', Fowler, effects of, on the soil (Culpin), 1936, 26, 45 
Haomoglobin level of cows and sheep, observations on (Allcroft), 1941, 31, 320

Hair growth and shedding in the guineapig, effect of pregnancy on (Strangeways), 1933, 23, 379

growth in the guinea-pig, conditions and factors affecting (Strangeways), 1933, 23, 359

'Hairgrass', data on, with a note on inorganic constituents (Rutledge and Common), 1945, 35, 123

Harvesting, premature, on the behaviour in the field of small grain obtained by (Hatcher and Purvis), 1945, 35, 177

Hay, artificially dried, digestibility of (Watson and Ferguson), 1932, 22, 247

botanical composition and yield of, effect of manures and lime on (Jacques), $1933,23,146$

carotene in, factors affecting the stability and estimation of (Kon and Thompson), $1940,30,622$

lucerne, see Lucerne

-making and storage, stability of carotene in plant material with special reference to (Seshan and Sen), 1942, 32, 275

-making, losses entailed during (Watson, Ferguson and Horton), 1937, 27, 224

meadow-, land, manuring of (Jacques), $1933,23,146$

meadow, yields and composition of, from certain plots at Cockle Park (Elliott and Thomas), 1934, 24, 379

seeds, composition and nutritive values of (Ferguson and Watson), 1944, 34, 88

time of cutting, and the losses entailed during haymaking (Watson, Ferguson and Horton), 1937, 27, 224

Heat in sheep, induction of (Hammond, Hammond and Parkes), 1942, 32, 308

of wetting measurements, application of, to soil research problems (Janert), $1934,24,136$

Heather, common, on the composition of (Thomas), 1934, 24, 151

Heifers, lactation in, induced by oestrogen implants (Day and Hammond), 1945, 35,150

Helminthosporium, see Stripe diseases

Herbage, see Pasture

Herd size and its genetical significance in pedigree cattle breeding (Donald and El Itriby), 1945, 35, 84

Heteroauxin in soils, estimation of traces of (Parker-Rhodes), 1940, 30, 654

Heterogeneity in the yields of agricultural crops, empirical law describing (Smith), 1938, 28, 1

Hide-fleshings, digestibility of (Bondi and Meyer), 1944, 34, 118
Hormones, gonadotrophic, ovulation and the descent of the ovum in the fallopian tube of the mare after treatment with (Day), 1939, 29, 459

hormonal augmentation of fertility in sheep (Hammond, Hammond and Parkes), 1942, 32, 308

Horse(s), barley straw for, effect of Beckmann's treatment by sodium hydroxide on the digestibility and feeding value of (Williamson), 1941, 31, 488

grass sickness in, soil properties in relation to the occurrence of (Stewart), $1941,31,308$

see also Mare, Stallion

Humic acids, natural and artificial (Du Toit and Page), 1932, 22, 115

materials prepared from coal, fertilizing value and nitrifability of (Crowther and Brenchley), 1934, 24, 156

matter of soil, origin of (Page), 1932, 22, 291

Husks, legume, see Legume

Hybrid vigour in wheat (Engledow and $\mathrm{Pal}), 1934,24,390$

Hydrogen, exchangeable, content of soils, comparison of four methods for the estimation of the (Innes and Birch), $1945,35,236$

-ion concentration and the interfacial ten. sion of pyrethrum extracts (Hobson), $1931,21,101$

-ion concentration in soils, see Soils

-ion concentration of the semen of the bull (Anderson), 1942, 32, 298

-ion concentration of the semen of the bull after incubation, change in (Anderson), 1944, 34, 69

-ion concentration, significance of the determination in the evaluation of quality in silages (McLean), 1941, 31, 518

peroxide, decomposition of soil organic matter by, influence of hydrogen-ion concentration on (Hosking), 1932, 22, 92

peroxide, effect of, on soil organic matter (McLean), 1931, 21, 251

peroxide, nature of soil organic matter as shown by the attack of (McLean), $1931,21,595$

Ignition at low temperatures of the organic matter in soils (Hosking), 1938, 28, 393

mlumination, growing sugar beet under continuous, experiments on (Bell and Bauer), 1942, 32, 112; 1943, 33, 85

Implements, cultivation, soil structure and the crop, relation between (Culpin), $1936,26,22,45 ; 1937,27,432$

Incubation temperature, see Temperature Insecticides, see Pyrethrum 
Intestinal putrefaction, chick, mechanism of infection in six.day disease with special reference to (Mann), 1945, 35, 108

Ions, exchangeable, in the soil, relationships between the sticky point and (Coutts), 1935, 25, 523

Irrigation, effect of, on soil salts (Greene and Peto), 1934, 24, 42

interrelation of factors controlling the production of cotton under (Gregory, Crowther and Lambert), 1932, 22, 617

Kale, marrow stem and thousand head, composition and nutritive value of (Woodman, Evans and Eden), 1936, 26,212

Karaka tree, distribution of copper in (Pitcaithly and Worley), 1933, 23, 204

Ketonuria and acetonuria, alimentary, in dairy cattle induced by feeding grass silage of the butyric acid type (Brouwer and Dijkstra), 1938, 28, 695

Kjeldahl method as applied to soil and grass analysis, selenium as a catalyst in (Ashton), 1936, 26, 239

Lactation, individual, analysis of the time change in milk production in (Gooch), $1935,25,71$

in heifers induced by oestrogen implants (Day and Hammond), 1945, 35, 150 .

Lambs, effects of different methods of docking and castration on the growth of (Garner and Sanders), 1936, 26, 296

pre-natal development of the coat of the New Zealand Romney (Galpin), 1935, 25, 344

swayback disease of, some observations on (Shearer and McDougall), 1944, 34, 207

Latin squares, see Statistics

Lattice squares, see Statistics

Leaching, winter, and the manurial value of green manures and crop residues (Crowther and Mirchandani), 1931, 21, 493

Leaf analysis as a means of diagnosing nutrient requirements of tropical orchard crops (Hardy, McDonald and Rodriguez), 1935, 25, 610

area, estimation of, in field crops (Watson), 1937, 27, 475

Leg weakness, deforming, in chickens, factors in the development of (Parkhurst and McMurray), 1933, 23, 311

rachitic, and growth in chickens, relation of calcium and phosphorus to (Parkhurst and McMurray), 1932, 22, 874

Legume(s) and non-legumes, excretion of nitrogen in associated cultures of (Virtanen, von Hausen and Laine), $1937,27,584$

JASI ii
Legume(s) husks, nutritive value of (Linton, Wilson and Watson), 1934, 24,260

limited numbers of nodules produced on, by different strains of Rhizobium (Chen), 1941, 31, 479

Leguminous plants, excretion of nitrogen by (Wilson and Burton), 1938, 28, 307

root-nodule bacteria of, investigations on (Virtanen and von Hausen), 1935, 25, 278, 290; 1936, 26, 281; (Virtanen, von Hausen and Laine), 1937, 27, 332, 584; (Vartiovaara), 1937, 27, 626

Lehmann method of pig feeding with particular reference to the balance of the basal meal and the use of cooked potatoes and molassed beet pulp as the supplemental foods (Woodman and Evans), 1943, 33, 155

Lettuce, May King, phosphate deficiency and yield tests on sand cultures of (Woodman), 1939, 29, 229

Leys, four-year, inclusion of red clover in (Garner and Sanders), 1939, 29, 164

Lime, effect of, on sheep fed on a calcium deficient ration (Auchinachie and Fraser), 1932, 22, 560

effect of, on the botanical composition and yield of hay (Jacques), 1933, 23, 146

effects of, on typical soils from North. East Scotland (Mitchell), 1936, 26, 664; (Whelan), 1939, 29, 306

influence of, on replaceable bases of a light acid soil (Crowther and Basu), $1931,21,689$

status of soils, use of $p$-nitrophenol for assessing (Schofield), 1933, 23, 252

Limestone, ground, effect of varied dressings in.the field (Nicholson), 1931, 21, 262

Litter size and duration of pregnancy, statistical analysis of the interrelations of, on the birth weight of rabbits (Wishart and Hammond), 1933, 23, 463 weaning weight of pigs and litter sampling with reference to (Smith and Donald), $1937,27,485$

Lodging in cereals, some factors influencing (Brady), 1934, 24, 209

Lolium, see Rye-grass

Low temperature, see Temperature, low

Lucerne and grass mixture, effect of sodium nitrate on the growth and nitrogen content of (Thornton and Nicol), 1934, 24, 269

hay, composition, digestibility and nutritive value of (Woodman and Eden), $1935,25,50$

influence of systematic cutting at three different stages of growth on the yield, composition and nutritive value of (Woodman, Evans and Norman), 1934, 24, 283 
Lucerne leaf meal, composition, digestibility and nutritive value of (Woodman and Eden), 1935, 25, 50

leaf-stem ratio (Woodman and Erans), $1935,25,578$

meal, composition, digestibility and nutritive value of (Woodman and Eden), 1935, 25, 50

nitrogen uptake of grass grown with (Thornton and Nicol), 1934, 24, 540

nutritive value of (Woodman, Evans and Norman), 1933, 23, 419; 1934, 24, 283; (Woodman and Eden), 1935, 25, 50; (Woodman and Evans), 1935, 25, 578

reduction of nodule numbers and growth produced by the addition of sodium nitrate to, in sand culture (Thornton and Nicol), 1936, 26, 173

root development of, some effects of clipping the tops upon (Thornton and Nicol), 1934, 24, 532

studies with-row distances and 'smother' crops (Garner and Sanders), $1940,30,182$

see also Alfalfa

Magnesium deficiency in some crop plants in relation to the level of potassium nutrition (Walsh and O'Donohoe), $1945,35,254$

Maintenance requirement of the adult sheep, method of calculating (Hendricks and Titus), 1931, 21, 726

Maize meal (cooked), degermed, value of, in the nutrition of swine (Woodman and Evans), 1932, 22, 670

meal, white, and Sussex ground oats for fattening cockerels, determination of the comparative net energy of (Deighton and Hutchinson), 1940, 30, 463

Manganese deficiency disease: marsh spot of peas (Piper), 1941, 31, 448

deficiency, susceptibility of cereal varieties to (Gallagher and Walsh), 1943, 33, 197 in soil, availability of (Piper), 1931, 21,762 in the pea seed in relation to marsh spot, distribution of (Glasscock and Wain), $1940,30,132$

readily soluble, of soils and marsh spot of peas (Heintze), 1938, 28, 175

sulphate, fate of, in alkaline soils (Wain, Silk and Wills), 1943, 33, 18

Mangels, see Mangolds

Mangolds, dry matter in, estimation of (Elphick and McMahon), 1935, 25, 1

for pigs, war-time rations (Braude and Foot), 1942, 32, 70

yield of, influence of rainfall on (Kalamkar), 1933, 23, 571

yield of, statistical examination of (Kalamkar), 1933, 23, 161
Manure(s), ammonium nitrogen see Ammonium nitrogen

ammonium sulphate, see Ammonium sulphate

ammonium sulphite, see Ammonium sulphite

calcium cyanamide, see Calcium cyana. mide

coal, fertilizing value and nitrifiability of humic materials prepared from (Crowther and Brenchley), 1934, 24, 156

composts, see Composts

crop residues, winter leaching and the manurial value of, for winter wheat (Crowther and Mirchandani), 1931, 21, 493

effect of, on the botanical composition and yield of hay (Jacques), 1933, 23, 146

effect of, on the composition of tomato foliage (Owen), 1931, 21, 442

farmyard, changes in the microflora and their relation to nitrification (Jensen), $1931,21,38$

farmyard, decomposition of cellulose in (Jensen), 1931, 21, 81

farmyard, microbiology of decomposition in soil (Jensen), 1931, 21, 38, 81 ; 1932, 22,1

farmyard, the obligate anaerobic microflora of (Glathe and Cunningham), $1933,23,540$

green, decomposition of, in soil (Daji), $1934,24,15$

green, effects of, on the ammonia and nitrate contents of soils cropped for winter wheat (Mirchandani), I93I, 21, 458

green, winter leaching and the manurial value of, for winter wheat (Crowther and Mirchandani), 1931, 21, 493

guanidine, see Guanidine

guano, see Guano

influence of, on baking quality of English wheat (Fisher and Jones), 1931, 21, 574

manuring of meadow-hay land (Jacques), $1933,23,146$

nitrate nitrogen, see Nitrate nitrogen

nitrogenous, effect of applying to wheat at different stages of growth (Watson), $1936,26,391$

nitrogenous, effect of, on the calcium status of soil (Lewis), 1938, 28, 197

nitrogenous, effect of time and rate of application on the yield of wheat (Lewis, Procter and Trevains), 1938, 28, 618

nitrogenous, field experiments on the effect of applying to wheat at different stages of growth (Watson), 1939, 29, 379 
Manure(s) nitrogenous, grassland treatment with (Gardner, Hunter-Smith and Williams), 1931, 21, 780

nitrogenous, see also Nitrogen

sodium nitrate, see Sodium nitrate superphosphate, see Superphosphate urea, see Urea

see also Fertilizers

Manurial treatment, influence of, on the carotene content of poor pasture grass, and on the relationship of this constituent to the ash and organic fractions (Moon), 1939, 29, 524

treatment, influence of rainfall on the yield of cereals in relation to (Cochran), $1935,25,510$

value of green manures and crop residues for winter wheat, winter leaching and (Crowther and Mirchandani), 1931, 21, 493

Mare(s) milk, composition of (Linton), $1931,21,669$

oestrous cycle of, following removal of the foetus at various stages of pregnancy (Day), 1939, 29, 470

ovulation and the descent of the ovum in the fallopian tube of, after treatment with gonadotrophic hormones (Day), $1939,29,459$

reproduction in, clinical and experimental observations on (Day), 1940, 30,244

survival of spermatozoa in the genital tract of (Day), 1942, 32, 108

survival of stored spermatozoa in the genital tract of (Laing), 1943, 33, 64

Marrow-stem kale, see Kale

Marsh spot, distribution of manganese in the pea seed in relation to (Glasscock and $\left.W_{\text {ain }}\right), 1940,30,132$

of pea seed, soils in relation to (Furneaux and Glasscock), 1936, 26, 59

of peas: a manganese deficiency disease (Piper), 1941, 31, 448

of peas, readily soluble manganese of soils and.(Heintze), 1938, 28, 175

Mating, effect of method of management at, on bovine fertility (Laing), 1945, 35, 25

Meadow-hay, see Hay

Meal, broad-bean-pod, see Bean

dreg, see Dreg meal

meat, see Meat

maize, see Maize

pea-pod, see Pea

potato, see Potato

sago pith, see Sago pith meal

white maize, see Maize

Meat, beef, food value of, from steers and heifers and its relation to dressing-out percentage (Callow), 1944, 34, 177

grading: the prices given for carcasses of different weights and qualities (Ham. mond and Murray), 1934, 24, 233
Meat meal of widely differing fat content, composition and digestibility, when fed to pigs, of three grades of (Wood. man and Evans), 1937, 27, 465

meals of widely differing fat content in the rations of bacon pigs, influence on growth, conformation and carcass quality of including (Woodman and Evans), 1939, 29, 502

qualities in the sheep with special reference to Scottish breeds and crosses (Pálsson), 1939, 29, 544; 1940, 30,1

Mechanical analysis, subdivision of the clay fraction in (Russell), 1943, 33, 147 soil, see Soil

Medicago sativa L., see Lucerne

Mercury, disinfectant dusts containing, outline of an investigation on (Weston and Booer), 1935, 25, 628

disinfectant dusts containing, seed protection by the use of (Brett, Weston and Booer), 1937, 27, 53

dust disinfectants, large-scale field trials on the disinfection of seed corn with (Weston, Hanley and Booer), 1937, 27, 43

organo-, seed disinfectants, loss of vitality during storage of grain treated with (Brett and Weston), 1941, 31, 500

Metabolic products, gaseous, of sheep, identification and measurement of the combustible gases that occur in (Lugg), 1938, 28, 688

Metabolism and surface area measurements of pigs (Deighton), 1937, 27, 317

effect of activity on (Deighton and Hutchinson), 1940, 30, 141

effect of diet on vitamin $A$, xanthophyll and carotene (Mann), 1945, 35, 101

fasting, of various breeds of hog (Deigh. ton), 1934, 24, 326; 1935, 25, 180; $1937,27,317$

mineral and protein, influence of highprotein intake on (Woodman, Evans and Turpitt), 1937, 27, 569

mineral, of pullets, observations on (Common), 1933, 23, 555; 1936, 26, $85 ; 1938,28,341 ; 1940,30,113$; 1941, 31,281 ; (Common and Hale), 1941, 31, 415; (Common), 1943, 33, 213

mineral, teart pastures of Somerset (Ferguson, Lewis and Watson), 1943, $33,44,52,58,116$

of fowls, calorimeter for the direct determination of (Deighton), 1939, 29, 431

of fowls, studies on (Deighton), 1939, 29, 431; (Deighton and Hutchinson), $1940,30,141,463$

protein and mineral, influence of high. protein intake on (Woodman, Evans and Turpitt), 1937, 27, 569 
Metallic compounds, action on the growth of crops of small percentages of, when applied with ordinary fertilizers (Brenchley), 1932, 22, 704

Meteorological factors, relation of drainage to rainfall and (Sahni), 1941, 31, 110

Methionine, effect of administration of, on the growth of wool of a Merino ewe on a protein-poor ration (Marston), $1935,25,113$

Microbiology of farmyard manure decomposition in soil (Jensen), 1931, 21, 38,$81 ; 1932,22,1$

of grassland soils, studies on (Eggleton), 1934, 24, 416

Microflora, changes in, and their relation to nitrification of farmyard manure (Jensen), 1931, 21, 38

obligate anaerobic, of farmyard manure (Glathe and Cunningham), 1933, 23, 527

Micro-organisms, decomposition of the cells of (Jensen), 1932, 22, 1

soil, comparison of two agar media for counting (Jensen), 1931, 21, 832

Milk, dried skim, for pigs, war-time rations (Braude and Foot), 1942, 32, 70

mare's, composition of (Linton), 1931, 21, 669

production, analysis of time change in, in individual lactations (Gooch), 1935, 25,71

production, effect of feeding concentrated and bulky foods prior to calving on (Blaxter), 1944, 34, 27

production, effect of over- and underfeeding during mid-lactation (Blaxter), $1944,34,213$

production, influence of changes in level of feeding on (Yates, Boyd and Pettit), $1942,32,428$

production, use of home-grown foods for, experiments on (Blaxter and French), $1944,34,22,27,213,217$

quality of, nutritive value of artificially dried grass and its effect on (Watson and Ferguson), 1936, 26, 189

quality of, value of artificially dried grass, silage made with added molasses and A.I.V. fodder in the diet of the dairy cow and their effect on (Watson and Ferguson), 1936, 26, 337

secretion, conformation of the cow as related to (Gowen), 1933, 23, 485

secretion, conformation of the parents as related to (Gowen), 1933, 23, 514

Milling control, influence of, on the composition, digestibility and nutritive value of wheaten offals (Woodman and Evans), 1944, 34, 35

practice, effect of war-time changes in, on the composition and nutritive value of fine and coarse wheat bran (Halnan), 1944, 34, 133
Mineral(s) balance studies on poultry (Common), 1932, 22, 576

composition of the soils of South Ayrshire (Elder and McCall), 1936, 26, I

composition of the tea leaf, seasonal and sampling variation in (Eden), 1932, 22, 386

identification of, in soil colloids (Nagelschmidt), 1939, 29, 477

in pasture, see Pasture

in the clay fractions of a black cotton soil and a red earth from Hyderabad, India (Nagelschmidt, Desai and Muir), 1940, 30, 639

metabolism, see Metabolism, mineral oils, see Oils

Mineralogy of the soil parent materials (Hart), 1941, 31, 438

Mole-drains, see Drainage and Drains

Mortality, chick, effect of diet on, with special reference to six-day disease (Mann), 1945, 35, 95

fertility, and growth rate in pigs (Menzies. Kitchin), 1937, 27, 611

in the domestic fowl, relation of production to (Munro), 1936, 26, 101

Mould, development of, on the cut surfaces of potato tubers (Weston and Taylor), $1944,34,93$

Mud, radioactive, some effects of, upon germination of seeds and growth of seedlings (Havas), 1935, 25, 198

Mushroom, cultivated, investigations into the environment and nutrition of (Pizer), 1937, 27, 349; (Pizer and Thompson), 1938, 28, 604

effect of calcium and phosphate on growth and productivity (Pizer and Thompson), 1938, 28, 604

growth of the mycelium, some properties of composts in relation to (Pizer), $1937,27,349$

Net energy, see Energy

Nitrate and ammonia contents of soils cropped for wheat, effect of summer green manures on (Mirchandani), 1931, 21, 458

nitrogen and ammonium nitrogen, effects of, on the growth of perennial rye-grass (Lew1s), 1936, 26, 249

sodium, see Sodium

Nitrification, effect of calcium cyanamide decomposition in the soil on (Crowther and Richardson), 1932, 22, 300

in soils, micro-biological aspects of (Mukerji), 1932, 22, 335

in Sudan Gezira soil (Jewitt), 1945, 35, 264

of farmyard manure, changes in the microflora and their relation to (Jensen), 1931, 21, 38 
Nitrogen, ammonium, see Ammonium nitrogen

and carbon cycles in soil (Du Toit and Page), 1932, 22, 115; (Page), 1932, 22 291; (Hobson and Page), 1932, 22, $297,497,516$

and carbon transformations in waterlogged soils (Sreenivasan and Subrahmanyan), 1935, 25, 6

and organic carbon in soils, examination of methods for (Walkley), 1935, 25, 598

and phosphorus contents of pasture, relationship between (Greenhill and Page), 1931, 21, 220

balance of laying hens (Willcox), 1934, 24,636

compounds in wheat during growth, amounts and distribution of (Knowles and Watkin), 1932, 22, 755

content of a lucerne and grass mixture, effect of sodium nitrate on the growth and (Thornton and Nicol), 1934, 24, 269

content of certain varieties of barley, relation of ear survival to (Hunter and Hartley), 1938, 28, 472

cycle in grassland soils (Richardson), $1938,28,73$

effect of, on the yield, composition and digestibility of grassland herbage (Watson, Procter and Ferguson), 1932, 22, 257

excretion of, by leguminous plants (Wilson and Burton), 1938, 28, 307

excretion of, effect of air content of the medium on (Virtanen and von Hausen), 1935, 25, 278

excretion of, in essociated cultures of legumes and non-legumes (Virtanen, von Hausen and Laine), 1937, 27, 584

fixation by the endophyte of Lolium (Brown), 1933, 23, 527

fixation, effect of temperature on a mixed culture of two organisms in symbiotic relation (Richards), 1939, 29,302

fixation, see also Bacteria

fractionation of, of certrin soils and its relation to their quality (Ashworth), $1942,32,349$

in barley grain, factors influencing the percentage of (Yates and Watson), $1939,29,452$

influence of successive applications on composition and yield of herbage (Shutt and Hamilton), 1934, 24, 341

inorganic, effect of time of application of, on the turnip (Woodman and Paver), $1944,34,49$

nitrate, see Nitrate nitrogen

organic, compounds of the soil, nature of: 'humic' nitrogen (Hobson and Page), $1932,22,497$
Nitrogen, organic, compounds of the soil, nature of; 'non-humic' nitrogen (Hobson and Page), 1932, 22, 516

organic, in soil, extraction of, with alkali (Hobson and Page), 1932, 22, 297

photosynthesis in the ear of barley, and the movement of, into the ear (Watson and Norman), 1939, 29, 321

response of permanent grassland to, and the efficiency of its recovery (Gardner), $1939,29,364$

supply, influence of temperature and, on growth of pasture in the spring (Blackman), 1936, 26, 620

uptake in mixed crops not receiving nitrogenous manure (Nowotnówna), $1937,27,503$

uptake of grass grown with lucerne (Thornton and Nicol), 1934, 24, 540

Nitrogenous compounds, influence of various factors on the excretion of, from the nodules of leguminous plants (Virtanen, von Hausen and Laine), 1937, 27, 332

fertilizers, see Manures, nitrogenous manures, see Manures, nitrogenous

$p$-Nitrophenol, use of, for assessing lime status of soils (Schofield), 1933, 23, 252

Nodule(s) bacteria, see Bacteria

development and function of, effect of air content of the medium on (Virtanen and von Hausen), 1935, 25, 290; 1936, 26, 281

limited numbers of, produced on legumes by different strains of Rhizobium (Chen), 1941, 31, 479

numbers and growth, reduction of, produced by the addition of sodium nitrate to lucerne in sand culture (Thornton and Nicol), 1936, 26, 173

of leguminous plants, influence of various factors on the excretion of nitrogenous compounds from (Virtanen, von Hausen and Laine), 1937, 27, 332

Nutrient requirements of tropical orchard crops, leaf analysis as a means of diagnosing (Hardy, McDonald and Rodriguez), 1935, 25, 610

Nutrition, animal, see Animal nutrition

of the carrot (Woodman and Paver), $1945,35,30$

of vegetables, studies in (Woodman), $1939,29,229$

Oat(s), carotene and protein in, at different stages of growth (Smith and Robb), $1943,33,119$

huskless, digestion of, by poultry (Moon and Thomas), 1937, 27, 458

stripe diseases of (Weston and Taylor), $1943,33,23$ 
Oat(s), Sussex ground, and white maize meal for fattening cockerels, determination of comparative net energy of (Deighton and Hutchinson), 1940, 30, 463

value of, in the nutrition of swine (Woodman, Evans and MenziesKitchin), 1932, 22, 657

varieties, yield characters of, in relation to cereal breeding technique (Stephens), $1942,32,217$

winter-hardiness in, determination of (Mather and Andersson), 1934, 24, 627

winter, improvement of (Hunter), 1935, 25,419

Oestrogen implants, lactation in heifers induced by (Day and Hammond), $1945,35,150$

Oestrous cycle of the mare following removal of the foetus at various stages of pregnancy (Day), 1939, 29, 470

Oestrus, periodicity and duration of, in zebu and grade cattle (Anderson), 1944, 34, 57

Offals, wheat, see Wheat offals

Oil(s), cod-liver, see Cod-liver oil

effect of feeding, to dairy cows (Garner and Sanders), 1938, 28, 543

glyceride, fungicidal properties of (Martin and Salmon), 1933, 23, 228

mineral, fungicidal properties of (Martin and Salmon), 1931, 21, 638

tar, fungicidal properties of (Martin and Salmon), 1931, 21, 638

vegetable, fungicidal properties of (Martin and Salmon), 1931, 21, 638

Organic carbon and nitrogen in soils, examination of methods for (Walkley), 1935, 25, 598

constituents in North-East Scottish soils, proximate analysis of (Shewan), 1938, 28, 324

matter, changes occurring in, during the decomposition of compost heaps (Ashworth), 1942, 32, 360

matter, soil, see Soil, organic matter

nitrogen, see Nitrogen

Orthogonality, see Statistics

Osmotic pressure of the contents of the stomach compartments of the sheep, notes on (Davey), 1936, 26, 328

Oviduct, hen's, carbonic anhydrase activity of the (Common), 1941, 31, 412

Ovulation and superovulation in sheep induction of (Hammond, Hammond and Parkes), 1942, 32, 308

and the descent of the ovum in the fallopian tube of the mare after treatment with gonadotrophic hormones (Day), 1939, 29, 459

in the cow, control of (Hammond and Bhattacharya), 1944, 34, 1

in the ewe (Anderson), 1938, 28, 64
Orum in the fallopian tube of the mare after treatment with gonadotrophic hormones, ovulation and descent of (Day), 1939, 29, 459

Oxidation of organic matter in the mechanical analysis of soils, use of sodium hypobromite for (Troell), 1931, 21, 476

-reduction potential measurements, use of the glass electrode in (Heintze), $1934,24,28$

Palm-kernel meal, extracted, value of, in the feeding of the bacon pig (Woodman and Evans), 1945, 35, 44

Papain, see Papaya

Papaya, extraction of papain from (Sen), 1931, 21, 209

Paralysis and avitaminosis $A$ in swine (Dunlop), 1934, 24, 435

Parasitic gastritis in sheep, epidemiology of (Taylor), 1934, 24, 192

Pasturage, proteins of, observations on (Foreman), 1938, 28, 135

Pasture grass, cystine content of (Evans), $1931,21,806$

grass, influence of manurial treatment on the carotene content of poor, and on the relationship of this constituent to the ash and organic fractions (Moon), $1939,29,524$

grass, sulphur of (Evans), 1931, 21, 806

grass, yields and composition of, from the Tree Field Plots at Cockle Park (Thomas and Elliott), 1932, 22, 736

growth of, in the spring, influence of temperature and available nitrogen supply on (Blackman), 1936, 26, 620

heavy-land, influence of cutting at monthly intervals on quality and productivity of (Woodman and Evans), $1938,28,581$

herbage, effect of nitrogen on the yield, composition and digestibility of (Watson, Procter and Ferguson), 1932, 22, 257

herbage, influence of successive applications of nitrogen on composition and yield of (Shutt and Hamilton), 1934, 24, 341

herbage, grassland, carotene content of certain species of (Smith and Wang), $1941,31,370$

high-protein (Shutt, Hamilton and Selwyn), 1932, 22,647

influence on yield and composition of a single heavy dressing of sulphate of ammonia compared with periodic small dressings (Woodman, Evans and Oosthuizen), 1938, 28, 598

management, rotational or close-grazing system of (Shutt, Hamilton and Selwyn), 1932, 22, 647 
Pastures, mineral content of (Greenhill and Page), 1931, 21, 220

mineral content of intensively treated (Ferguson), 1932, 22, 251

mineral content of, seasonal variation in, with special reference to drought (Ferguson), 1931, 21, 233

nitrogen and phosphorus contents, relationship between (Greenhill and Page), 1931, 21, 220

nutritive value of (Woodman, Norman and French), 1931, 21, 267; (Woodman and Underwood), 1932, 22, 26; (Woodman and Norman), 1932, 22, 852 ; 1934, 24, 93; (Woodman and Oosthuizen), 1934, 24, 574; (Woodman and Evans), 1938, 28, 581, 592; (Woodman, Evans and Oosthuizen), $1938,28,598$

residual effects of the intensive use of sulphate of ammonia on (Woodman and Evans), 1938, 28, 592

small plot productivity experiments, relative importance of plot variation and of field and laboratory sampling errors in (Bartlett and Greenhill), 1936, 26, 258

teart, cause and cure of (Ferguson, Lewis and Watson), 1943, 33, 44

teart, effect of continuous administration of copper sulphate to dairy cows (Ferguson), 1943, 33, 116

teart, of Somerset (Ferguson, Lewis and Watson), 1943, 33, 44, 52, 58, 116

teart, reducing the teartness of (Lewis), $1943,33,58$

teart, relation between soil and teartness (Lewis), 1943, 33, 52

Pea(s)-canning by-products, chemical composition and nutritive value of (Wood. man and Evans), 1944, 34, 155

genetical analysis of the seed characters wrinkled, dimpled and smooth in (Hadfield and Calder), 1935, 25, 264

germination of, experiments on (Brett, Weston and Booer), 1937, 27, 53

inoculated, growth of the root-nodule organisms and, at low temperatures (Vartiovaara), 1937, 27, 626

marsh spot of: a manganese deficiency disease (Piper), 1941, 31, 448

marsh spot of, readily soluble manganese of soils and (Heintze), 1938, 28,175

-pod meal, composition and nutritive value, when fed to ruminants (Woodman and Evans), 1940, 30, 189

seed, distribution of manganese in, in relation to marsh spot (Glasscock and Wain), 1940, 30, 132

seed protection by the use of disinfectant dusts containing mercury (Brett, Weston and Booer), 1937, 27, 53
Pea(s) seed, soils in relation to marsh spot of (Furneaux and Glasscock), $1936,26,59$

Peat, organic transformations in (Duthie), $1937,27,162$

Pennisetum purpureum, see Grass, elephant

Percolation through drain gauges, effects of rainfall and temperature on (Koshal), $1934,24,105$

Permeability of saturated sands, soils and clays (Carman), 1939, 29, 262

Perosis, see Leg weakness

$p F$ in soil, see Soil

pH, see Hydrogen-ion concentration

Phosphatase, serum, in the domestic fowl (Common), 1936, 26, 492

Phosphate and calcium, effect of, on growth and productivity of the cultivated mushroom (Pizer and Thompson), 1938, 28, 604

deficiency and yield tests on sand cultures of May King lettuce (Woodman), 1939, 29,229

fixation in Scottish soils, studies on (Williams and Stewart), 1943, 33, 179

potassium, dihydrogen, use of, in studying base exchange capacity of soils (Schofield), 1933, 23, 255

recovery of added, from a soil of the acid igneous group (Williams and Stewart), $1943,33,179$

Phosphoric acid in soils, new method for the determination of total (Shrik. hande), 1942, 32, 406

Phosphorus and calcium balances with laying birds (Tyler and Willcox), 1942, 32,43

and calcium combination in the excreta of the non-laying pullet, nature of (Knowles, Watkin and Hendry), 1933, 23, 196

and calcium, relation of, to growth and rachitic leg weakness in chickens (Parkhurst and McMurray), 1932, 22, 874

and nitrogen contents of pasture, relationship between (Greenhill and Page), $1931,21,220$

and protoplasm, observations on the proteins of pasturage (Foreman), 1938, 28,122

calcium and vitamin $D$ requirement of swine (Dunlop), 1935, 25, 22

compounds in wheat during growth, amounts and distribution of (Knowles and Watkin), 1932, 22, 755

in soils, determination of (McLean), 1936, 26, 331

soil, and other phosphorus compounds in sodium hydroxide solutions, solubility of (Williams), 1937, 27, 259 
Phosphorus, soil, attempted fractionation of (Dean), 1938, 28, 234

Photosynthesis in the ear of barley, and the movement of nitrogen into the ear (Watson and Norman), 1939, 29, 321

'Physin' factor, effect of, on the liveweight increase of swine (Dunlop), $1935,25,445$

Pig(s) bacon, back fat, effect of diet on the component fatty acids of (Shorland and De La Mare), 1945, 35, 33

bacon, body proportions of different breeds of (Hammond and Murray), $1937,27,394$

bacon, effect of the plane of nutrition on the form and conformation of (McMeekan), 1940, 30, 511

bacon, fats of, with reference to carcass quality (Shorland and De La Mare), $1945,35,33,39$

bacon, growth rate and carcass quality in. A study of polynomial coefficients fitted to growth rate data (Donald), $1940,30,582$

bacon, growth rate and chemical com. position of depot fat, relation between (Shorland and De La Mare), 1945, 35, 39

bacon, influence on growth, conformation and carcass quality of including meat meals of widely differing fat content in thè rations of (Woodman and Evans), $1939,29,502$

bacon, nature and variability of the carcass characters of Danish and English (McMeekan), 1939, 29, 131

bacon, nutrition of (Woodman, Callow, Evans, Turpitt and Wishart), 1936, 26, 546 ; 1937, 27, 569; 1939, 29, 115, 502; $1940,30,83 ; 1941,31,232 ; 1942,32$, $85 ; 1943,33,101,155 ; 1945,35,44$, 133

bacon, 'restricted' feeding of (Shorrock), $1940,30,598$

bacon, use of sample joints and of carcass measurements as indices of the composition of (McMeekan), 1941, 31, 1

bacon, value of lawn-grass cuttings in the feeding of (Woodman and Evans), $1943,33,101$

bacon, value of extracted palm-kernel meal in the feeding of (Woodman and Evans), 1945, 35, 44

bacon, value of potato peelings in the nutrition of (Woodman and Evans), $1943,33,15$

body temperature measurements (Deighton), $1935,25,180$

calcium, phosphorus and vitamin D requirement of (Dunlop), 1935, 25, 22 complex pig-feeding experiment (Yates), $1934,24,511$
Pig(s) composition and digestibility, when fed to, of potato cossettes and potato meal (Woodman and Evans), 1939, 29, 347

composition of, effect of a submaintenance diet on (Pomeroy), 1941, 31, 50

copper in the diet of fattening, some observations on the need for (Braude), $1945,35,163$

external characteristics in Essex pigs, behaviour of some (Olbrycht), 1944, 34,16

fasting metabolism of various breeds of (Deighton), 1934, 24, 326; 1935, 25, $180 ; 1937,27,317$

fat-soluble vitamin requirements of, during growth (Isaachsen), 1932, 22, 460

feeding, Lehmann method of, with particular reference to the balance of basal meal and the use of cooked potatoes and molassed beet pulp as the supplemental foods (Woodman and Evans), 1943, 33, 155

feeding experiment using dried Clostridium residue (Braude and Foot), 1942, 32,324

feeding experiments with cod-liver oil (Foot, Henry, Kon and Macintosh), $1939,29,142$

fertility, mortality, and growth rate in (Menzies-Kitchin), 1937, 27, 611

growth and development, influence of the plane of nutrition on (McMeekan), $1940,30,387,511$

growth and development in, with special reference to carcass quality characters (McMeekan), 1940, 30, 276, 387, 511; 1941, 31, 1

influence of high levels of protein intake on growth, conformation and quality in the bacon pig (Woodman, Evans, Callow and Wishart), 1936, 26, 546

influence of high-protein intake on protein and mineral metabolism (Woodman, Evans and Turpitt), 1937, 27, 569

live-weight increase of, effect of the growth-promoting, appetite-stimulat. ing or 'physin' factor on (Dunlop), $1935,25,445$

metabolism and surface area measurements (Deighton), 1937, 27, 317

minimum level of protein intake consistent with quick growth and satisfactory carcass quality (Woodman, Evans, Turpitt and Callow), 1939, 29, 115; (Woodman and Evans), 1940, 30, $83 ; 1941,31,232 ; 1945,35,133$

nutrition of, value of degermed maize meal (cooked) in (Woodman and Evans), 1932, 22, 670 
Pig(s) nutrition of, value of oats in (Woodman, Evans and Menzies-Kitchin), $1932,22,657$

nutrition of, value of tapioca flour and sago pith meal in (Woodman, MenziesKitchin and Evans), 1931, 21, 526

paralysis and avitaminosis $A$ in (Dunlop), $1934,24,435$

post-weaning growth in, analysis of (Smith and Donald), 1939, 29, 274

retention of protein by growing (Reimers and Bartel), 1935, 25, 397

selection in, statistical basis of (Olbrycht), $1943,33,28,74$

surface area of, determination of (Deighton), 1932, 22, 418

utilization of young grass by (Woodman and Norman), 1934, 24, 93

vitamin $A$ requirement of (Dunlop), $1935,25,217$

war-time rations for (Braude and Foot), $1942,32,70$

water consumption of suckling sows (Garner and Sanders), 1937, 27, 638

weaning weight of, and litter sampling with reference to litter size (Smith and Donald), 1937, 27, 485

Pisum, see Peas

Plant(s) breeding, see specific plants carotene in, development and distribution of (Seshan and Sen), 1942, 32, 202

copper deficiency in, investigations on (Piper), 1942, 32, 143

growth, action of small percentages of certain metallic compounds when applied with ordinary fertilizers (Brenchley), 1932, 22, 704

growth and development of rain-grown cotton, effects of varying soil consolidation on (Heath), 1937, 27, 511

growth and nitrogen content of a lucerne and grass mixture, effect of sodium nitrate on (Thornton and Nicol), 1934, 24, 269

growth, development of structural con. stituents in the barley plant (Norman), 1933, 23, 216

growth, distribution of some reserve substances in hard winter wheat at successive growth stages (Malhotra), 1932, 22, 485

growth, effect of ammonium sulphite on (Lewis and Marmoy), 1933, 23, 1

growth, effect of borax dressings on growth and yield of field beans (Vicia faba L.) (Owen, Snow and Thom), $1945,35,119$

growth, influence of time of cutting on, of tropical fodder grasses (Paterson), $1933,23,615$

growth of clover in the presence of ammonium sulphate (Caldwell and Richardson), 1936, 26, 263
Plant(s) growth of mushroom mycelium, some properties of composts in rela. tion to (Pizer), 1937, 27, 349

growth of pasture in the spring, influence of temperature and available nitrogen supply on (Blackman), 1936, 26, 620

growth of perennial rye grass, effects of ammonium and nitrate nitrogen on (Lewis), 1936, 26, 249

growth of seedlings, some effects of radioactive mud upon (Havas), 1935, 25,198

growth of the potato plant, some effects of fertilizer interactions on (Knowles, Watkin and Cowie), 1940, 30, 159

growth of wheat, assimilation and translocation of plant nutrients during (Knowles and Watkin), 1931, 21, 612

influence of, on seasonal changes in soil acidity (Smith and Robertson), 1931, 21, 822

material, stability of carotene in, with special reference to hay making and storage (Seshan and Sen), 1942, 32, 275

nutrients, assimilation and translocation of, in wheat during growth (Knowles and Watkin), 1931, 21, 612

Plasticity of soil, effect of climatic variations on (Blair and Yates), 1932, 22 639

Plot(s), arrangement, influence of, upon estimate of error in field experiments (Tedin), 1931, 21, 191

design of, for variety trials with cotton (MacDonald, Fielding and Ruston), $1939,29,35$

field-, technique with potatoes, experimental error and (Kalamkar), 1932, 22, 373

shape of, importance in field experimentation (Christidis), 1931, 21, 14

size and shape of, influence on precision of field experiments with potatoes (Justesen), 1932, 22, 366

technique with potatoes, experimental error and (Kalamkar), 1932, 22, 373

variation, and field and laboratory sampling errors in small plot pasture productivity experiments, relative importance of (Bartlett and Greenhill), $1936,26,258$

Polynomial coefficients, see Statistics

Pony stallion, sperm production of (Chang), $1943,33,67$

Porosity of eggs, function of the cuticle in relation to (Marshall and Cruickshank), $1938,28,24$

of egg shells and the influence of different levels of dietary calcium upon porosity (Tyler), 1945, 35, 168

Pot culture experiments, utilization of calcium cyanamide in (Richardson and Crowther), 1935, 25, 132 
Pot culture, sand and calcium bentonite as the growth medium in (Greenhill and Page), 1933, 23, 329

Potassium, movement of, in irrigated and fertilized red sandy clay (Lachower), $1940,30,498$

nutrition, magnesium deficiency in some crop plants in relation to the level of (Walsh and O'Donohoe), 1945, 35, 254

phosphate, dihydrogen, use of, in study. ing base exchange capacity of soils (Schofield), 1933, 23, 255

Potato(es), artificially dried, further investigations of the feeding value of (Woodman and Evans), 1943, 33, 1

cooked, and molassed beet pulp, use of, as supplemental foods (Woodman and Evans), 1943, 33, 155

cossettes, composition and digestibility of, when fed to pigs and sheep (Woodman and Evans), 1939, 29, 347

cossettes, composition and nutritive value of (Woodman and Evans), 1943, 33, 1

digestibility and metabolizable energy of raw and cooked, potato flakes, dried potato slices and dried potato shreds (Halnan), 1944, 34, 139

dried potato products for egg production: statistical analysis of a laying experiment (Bolton and Hale), 1945, 35, 158

dust, composition and nutritive value of (Woodman and Evans), 1943, 33, 1

experimental error and the field-plot technique with (Kalamkar), 1932, 22 , 373

flakes, composition and nutritive value of (Woodman and Evans), 1943, 33, I

influence of size and shape of plots on the precision of field experiments with (Justesen), 1932, 22, 366

maintenance of healthy stocks in England (Bryan), 1932, 22, 358

meal, composition and digestibility of, when fed to pigs and sheep (Woodman and Evans), 1939, 29, 347

meal, composition and nutritive value of (Woodman and Evans), 1943, 33, 1

peelings, value of, in the nutrition of the bacon pig (Woodman and Evans), $1943,33,15$

plant, some effects of fertilizer interactions on growth and composition of (Knowles, Watkin and Cowie), 1940, 30, 159

raw and cooked, feeding of, to laying pullets (Temperton and Dudley), 1943, 33, 204

slices, composition and nutritive value of (Woodman and Evans), 1943, 33, 1

tubers, development of mould on the cut surfaces of (Weston and Taylor), 1944 34, 93
Potato(es) tubers, experiments on cut. ting (Bell, Gilson and Weston), 1942, 32, 255

tubers, size of, study of the factors in. fluencing (Bates), 1935, 25, 297

wheat after, preparation of seed bed for (Garner and Sanders), 1936, 26, 415

yield of, effect of inter-row tillage on (Pereira), 1941, 31, 212

Poultry, acid-base equilibrium and reproductive activity in pullets (Common), 1941, 31, 281

body fat of, effect of different cereals in the fattening ration on the composition of (Cruickshank), 1937, 27, 309

calcium and phosphorus balances with laying birds (Tyler and Willcox), 1942, 32,43

calcium and phosphorus combination in the excreta of the non-laying pullet (Knowles, Watkin and Hendry) 1933, 23, 196

calcium requirement of the laying bird (Common), 1943, 33, 213

calcium requirements of, with particular reference to their needs for maintenance (Tyler and Willcox), 1942, 32, 62

calorimeter for the direct determination of the metabolism of (Deighton), 1939, 29,431

chick diets, value of whale-meat as a constituent of, observations on (Halnan), $1942,32,179$

chick, riboflavin requirement of the White Wyandotte (Bolton), 1944, 34, 198

chicken rearing (Mann), 1945, 35, 95, 98, $101,108,207,214,225,232$

chicken rearing experiments, experimental errors in (Hale), 1931, 21, 716

chickens, deforming leg weakness in, factors in the development of (Parkhurst and McMurray), 1933, 23, 311

chickens, growth and rachitic leg weakness in, relation of calcium and phosphorus to (Parkhurst and McMurray), 1932, 22, 874

cockerels, determination of the comparative net energy of Sussex ground oats and white maize meal for fattening (Deighton and Hutchinson), 1940, 30, 463

cockerels, some observations on the normal variations in composition of Light Sussex (Halnan), 1938, 28, 379

crossing the Rhode Island Red and White Leghorn breeds of, results of (Dudley), $1944,34,76$

diet, bacterial syndrome arising from, which is conducive to six-day disease (Mann), 1945, 35, 98

diet, effect of, on mortality with special reference to six-day disease (Mann), $1945,35,95$ 
Poultry, diet, effect of, on vitamin A, xanthophyll and carotene metabolism (Mann), 1945, 35, 101

digestibility and metabolizable energy of raw and cooked potatoes, potato flakes, dried potato slices and dried potato shreds (Halnan), 1944, 34, 139

digestibility of dried molassed sugar-beet pulp (Halnan), 1937, 27, 137

digestibility of dura, carobs and hidefleshings (Bondi and Meyer), 1944, 34, 118

digestibility of wheat offals (Halnan), $1937,27,126$

digestibility trials with (Halnan), 1937, $27,126,137 ; 1943,33,113 ; 1944,34$. 133, 139; (Bondi and Meyer), 1944, 34, 118

digestion of huskless orts by (Moon and Thomas), 1937, 27, 458

eggs, see Eggs

fattening of, influence of protein on (Halnan), 1938, 28, 341

fecundity in: behaviour of persistency in individual hens (Greenwood, Blyth and Galpin), 1940, 30, 202

feeding, up to the age of 16 weeks, relative values of genuine and a sample of controlled cod-liver oil in (Wright), $1941,31,161$

intestinal putrefaction, mechanism of infection in six-day disease with special reference to (Mann), 1945, 35, 108

metabolism, effect of activity on (Deigh. ton and Hutchinson), 1940, 30, 141

metabolism of, studies on (Deighton), 1939, 29, 431; (Deighton and Futchinson), 1940, 30, 141, 463 .

mineral balance studies on (Common), $1932,22,576$

mortality in the domestic fowl, relation of production to (Munro), 1936, 26, 101

nitrogen balance of laying hens (Willcox), $1934,24,636$

oviduct, carbonic anhydrase activity of the hen's (Common), 1941, 31, 412

pullets, feeding of raw and cooked potatoes and sugar beet to laying (Temperton and Dudley), 1943, 33, 204

pullets, mineral metabolism of, observations on (Common), 1933, 23, 555; $1936,26,85 ; 1938,28,347 ; 1940,30$, 113; 1941, 31, 281; (Common and Hale), 1941, 31, 415; (Common), 1943 , 33, 213

riboflavin requirement of the White Wyandotte chick (Bolton), 1944, 34, 198

serum phosphatase in the domestic fowl (Common), 1936, 26, 492
Poultry, shell formation, mobilization of body calcium for (Common and Hale), 1941, 31, 415

six-day disease, bacterial syndrome arising from a diet which is conducive to (Mann), 1945, 35, 98

six-day disease, effect of diet on mortality with special reference to (Mann), 1945, 35,95

six-day disease, mechanism of infection in, with special reference to intestinal putrefaction (Mann), 1945, 35, 108

vitamin $D_{3}$ requirement of pullet chicks (Wright), 1941, 31, 161

Pregnancy, duration of, and litter size, statistical analysis of the interrelations of, on the birth weight of rabbits (Wishart and Hammond), 1933, 23, 463

effect of, on hair growth and shedding in the guinea-pig (Strangeways), 1933, 23, 379

oestrous cycle of the mare following removal of the foetus at various stages of (Day), 1939, 29, 470

urine extract, see Chorionic gonadotrophin

Pre-natal development of the coat of the New Zealand Romney lamb (Galpin), $1935,25,344$

Progeny test as a method of evaluating the dairy sire (Edwards), 1932, 22, 811

Protein(s), high-protein pasture (Shutt, Hamilton and Selwyn), 1932, 22, 647

in oats and barley at different stages of growth (Smith and Robb), 1943, 33, 119

influence of, on the fattening of fowls (Halnan), 1938, 28, 341

intake, influence of high levels of, on growth conformation and quality in the bacon pig (Woodman, Evans, Callow and Wishart), 1936, 26, 546

intake, minimum level of, consistent with quick growth and carcass quality (Woodman, Evans, Turpittand Callow), 1939, 29, 115; (Woodman and Evans), $1940,30,83$

intake of sheep in relation to wool growth, variation in (Fraser and Roberts), 1933, 23, 97

metabolism, see Metabolism

of pasturage, observations on (Foreman), $1938,28,135$

retention of, by growing pigs (Reimers and Bartel), 1935, 25, 397

Protoplasm and phosphorus, observations on the proteins of pasturage (Foreman), $1938,28,122$

Psalliota campestris, see Mushroom

Pteridium aquilinum, see Bracken

Puccinia glumarum, see Rust 
Pullets, see Poultry

Pyrethrum dusts, loss of toxicity on exposure to air and light (Tattersfield), $1932,22,396$

extracts, calcium and hydrogen-ion concentration and the interfacial tension of (Hobson), 1931, 21, 101

flowers, chemical evaluation of (Martin), $1938,28,456 ; 1941,31,178$

flowers, evaluation of (Martin and Tattersfield), 1931, 21, 115

loss of activity of (Tattersfield and Martin), 1934, 24, 598

toxicity of, to Aphis rumicis (Martin and Tattersfield), 1931, 21, 122

Quality, baking, of English wheat, influence of manurial treatment on (Fisher and Jones), 1931, 21, 574

carcass, fats of the bacon pig with reference to (Shorland and De La Mare), 1945, 35, 33, 39

carcass, minimum level of protein intake consistent with quick growth and (Woodman, Evans, Turpittand Callow), 1939, 29, 115; (Woodman and Evans), $1940,30,83$

characters, carcass, growth and development in the pig with special reference to (McMeekan), 1940, 30, 276, 387

factor in feeding stuffs (Murray), 1933, 23,185

grain, differentiation of grain samples by means of a simple mechanical test for (Frankel), 1935, 25, 461

in silages, the significance of the $p H$ determination in the evaluation of (McLean), 1941, 31, 518

in the bacon pig, influence of high levels of protein intake on (Woodman, Evans, Callow and Wishart), 1936, 26, 546

meat, in the sheep with special reference to Scottish breeds and crosses (Pálsson), $1939,29,544 ; 1940,30,1$

of milk, nutritive value of artificially dried grass and its effect on (Watson and Ferguson), 1936, 26, 189

of milk, value of artificially dried grass, silage made with added molasses and A.I.V. fodder in the diet of the dairy cow and their effect on (Watson and Ferguson), 1936, 26, 337

soil, see Soil

Rabbit(s), birth weight of, a statistical analysis of the interrelations of litter size and duration of pregnancy on (Wishart and Hammond), 1933, 23, 463 carcasses, composition of (Wilson and Morris), 1932, 22, 453

carcass investigations with (Dudley and Wilson), 1943, 33, 129
Rabbit(s), effect of 'condition' on the colour of body fat in (Hirzel), 1935, 25, 541

excretion of copper in the, studies on (Eden), 1941, 31, 145

fecundity of male, as determined by 'dummy maatings' (Macirone and Walton), 1938, 28, 122

weights of, at time of killing, some observations on (Dudley and Wilson), $1943,33,129$

Rachilla length in barley, inheritance of (Bell and Carson), 1941, 31, 246

Rachitic leg weakness and growth in chickens, relation of calcium and phosphorus to (Parkhurst and McMurray), 1932, 22, 874

Radioactive mud, some effects of, upon germination of seeds and growth of seedlings (Havas), 1935, 25, 198

Rainfall and other meteorological factors, relation of drainage to (Sahni), 1941, 31, 110

effect of, on spring- and autumn dressed wheat ('Alumnus'), 1932, 22, 101

effects of, on percolation through drain gauges (Koshal), 1934, 24, 105

effects of, on yields of crops grown in rotation (Cowie), 1945, 35, 197

influence of, on the yield of cereals in relation to manurial treatment (Cochran), 1935, 25, 510

influence of, on the yield of mangolds (Kalamkar), 1933, 23, 571

Rams, adult, sperm production of, in relation to frequency of semen collection (Chang), 1945, 35, 243

Red clover, see Clover

Reproduction in the mare, clinical and experimental observations on (Day), $1940,30,244$

Reproductive activity, acid-base equilibrium and, in pullets (Common), 1941, 31, 281

Respiration rate and loss of dry matter from stored bran (Snow and Wright), $1945,35,126$

Respiratory exchange of fed sheep over periods of forty-eight hours, an apparatus and technique for measuring (Lines), 1938, 28, 663

rhythm in dairy cattle in the tropics, influence of environmental temperature on (Rhoad), 1936, 26, 36

Rhizobium, limited numbers of nodules produced on legumes by (Chen), 1941, 31, 479

Riboflavin requirement of the White Wyandotte chick (Bolton), 1944, 34, 198

Rice, uniformity trial with irrigated broadcast (Lord), 1931, 21, 178 
Rickets in sheep, relation between rates of growth and, on diets deficient in vitamin D (Duckworth, Godden and Thomson), 1943, 33, 190

Rolls, account of methods employed in a study of their actions on the soil (Culpin), 1937, 27, 432

Root(s) crops, placement of fertilizers (Lewis), 1941, 31, 295

lucerne, development of, some effects of clipping the tops upon (Thornton and Nicol), 1934, 24, 532

nodule bacteria, see Bacteria

red clover, effect of cutting on the carbohydrate reserves in (Virtanen and Nurmia), 1936, 26, 288

Rotation, effects of fertilizers and rainfall on yields of crops grown in (Cowie), $1945,35,197$

experiments with cotton in the Sudan Gezira (Crowther and Cochran), 1942, 32, 390

Rothamsted park grass experiment, nitrogen cycle in grassland soils: with especial reference to (Richardson), $1938,28,73$

Roughage carbohydrates, chemical nature and digestibility of (Bondi and Meyer), 1943, 33, 123

Rubber, value of a uniformity trial in field experimentation with (Murray), 1934, 24, 177

Rumen bacteria, see Bacteria

Ruminant(s), composition and nutritive value, when fed to, of pea-pod meal and broad-bean-pod meal (Woodman and Evans), 1940, 30, 189

organism, mechanism of cellulose digestion in (Woodman and Stewart), 1932, 22, 527; (Woodman and Evans), $1938,28,43$

Rust, wheat, certain toxic substances obtained from the wheat plant which inhibit the germination of the uredospores of (Parker-Rhodes), 1939,29, 399

Rye-grass, nitrogen fixation by the endophyte of (Brown), 1933, 23, 527

-grass, perennial, effects of ammonium and nitrate nitrogen on the growth of (Lewis), 1936, 26, 249

-grass, perennial, establishment in a mixture of sand and calcium bentonite (Greenhill and Page), 1933, 23, 329

-grass seed and rye-grass seed cleanings, composition and digestibility of North. ern Irish (Common), 1945, 35, 56; (Rutledge and Common), 1945, 35, 123

stripe smut of (Taylor and Weston), $1945,35,116$

Sago pith meal, value of, in the nutrition of swine (Woodman, Menzies-Kitchin and Evans), 1931, 21, 526
Samples, drying, an electric oven for (Garner, Grantham and Sanders), 1935, 25, 315

grain, differentiation of, by means of a simple mechanical test for grain quality (Frankel), 1935, 25, 461

Sampling errors in small plot pasture productivity experiments, relative importance of plot variation and (Bartlett and Greenhill), 1936, 26, 258

estimation of the efficiency of, with special reference to sampling for yield in cereal experiments (Yates and Zacopanay), 1935, 25, 545

for the ratio of grain to total produce, estimation of the yields of cereal experiments by (Cochran), 1940,30, 262

litter, with reference to litter size (Smith and Donald), 1937, 27, 485

observations on wheat, crop-weather scheme, an examination of (Barnard), $1936,26,456$

population studies with wheat (Hudson), $1939,29,76$

technique, studies in (Clapham), 1931, 21, 366, 376; (Simpson), 1931, 21, 372 technique with wheat, study in (Kalam. kar), 1932, 22, 783

Sand and calcium bentonite as the growth medium in pot culture (Greenhill and Page), 1933, 23, 329

culture, reduction of nodule numbers and growth produced by the addition of sodium nitrate to lucerne in (Thornton and Nicol), 1936, 26, 173

cultures of May King lettuce, phosphate deficiency and yield tests on (Woodman), 1939, 29, 229

grading of coarse and fine, during mechanical analysis of soils, improved technique in (Beater), 1937, 27, 123

permeability of saturated sands, soils and clays (Carman), 1939, 29, 262

Saturation capacity, determination of, in some tropical soil types (Turner), 1932, 22,72

Secretion, milk, see Milk secretion

Seed(s) beans, on the age of (Garner and Sanders), 1935, 25, 361

bed, influence of, on crop growth (Russell and Mehta), 1938, 28, 272

bed, preparation of, for wheat after potatoes (Garner and Sanders), 1936, 26, 415

buried, occurrence of, in the soil (Chippen. dale and Milton), 1932, 22, 451

characters, wrinkled, dimpled and smooth in Pisum, genetic analysis of (Hadfeld and Calder), 1935, 25, 264

corn, large-scale field trials on the disinfection of, with mercury dust disinfectants (Weston, Hanley and Booer), $1937,27,43$ 
Seed(s), cotton, treatment with sulphuric acid (Christidis), 1936, 26, 648

disinfection (Weston and Booer), 1935, 25, 628; (Weston, Hanley and Booer), 1937, 27, 43; (Brett, Weston and Booer), 1937, 27, 53; (Brett and Weston), 1941, 31, 500; (Weston and Taylor), 1943, 33, 23; (Taylor and Weston), 1945, 35, 116; (Weston and Taylor), 1945, 35, 239

disinfection, mechanical principles (Weston and Taylor), 1945, 35, 239

germination of, and growth of seedlings, some effects of radioactive mud upon (Havas), 1935, 25, 198

pea, distribution of manganese in, in relation to marsh spot (Glasscock and Wain), 1940, 30, 132

pea, soils in relation to marsh spot of (Furneaux and Glasscock), 1936, 26, 59

rate and time of thinning, effects of, on the development and yield of cotton plants in hand-planted cotton trials (MacDonald, Fielding and Ruston), $1939,29,418$

rates in nursery trials and field plots (Hudson), 1941, 31, 138

-setting in alfalfa, factors influencing (Armstrong and White), 1935, 25, 161 sunflower, see Sunflower

treatments, effects of, on germination and yield of sugar beet (Garner and Sanders), 1932, 22, 551

Selection in animal husbandry, statistical basis of (Olbrycht), 1943, 33, 28, 74

Selenium as a catalyst in the Kjeldahl method as applied to soil and grass analysis (Ashton), 1936, 26, 239

Semen, bull, change in $p \mathrm{H}$ of, after incubation (Anderson), 1944, 34, 69

bull, exchange of, between England and Holland (Edwards and Walton), 1938, 28, 503

bull, hydrogen-ion concentration of (Anderson), 1942, 32, 298

bull, rapid method of standardization of the density of (Kyaw), 1944, 34, 106

characteristics of, in relation to fertility in the bull (Laing), 1945, 35, I

collection, sperm production of adult rams in relation to frequency of (Chang), 1945, 35, 243

see also Spermatozoa

Serum phosphatase in the domestic fowl (Common), 1936, 26, 492

Sesquioxide components in soil, identi. fication and approximate estimation of, by adsorption of alizarin (Hardy), $1931,21,150$

Sheep, appetites of, measurements of, on typical winter rations (Woodman, Evans and Eden), 1937, 27, 191
Sheep, artificial insemination of (Anderson), 1937, 27, 143; 1941, 31, 354

blood copper of Northumbrian, further observations on (Eden), 1941, 31, 186

breeding season in (Hammond, jun.), $1944,34,97$

composition and digestibility, when fed to, of potato cossettes and potato meal (Woodman and Evans), 1939, 29, 347

development of the characters of the fleece during growth in the different regions of the body (Thomasset), 1938, 28,523

fed on a calcium deficient ration, effect of lime and cod-liver oil on (Auchinachie and Fraser), 1932, 22, 560

feeding standards, critical study of (Woodman, Evans and Eden), 1937, 27, 191

fertility in, hormonal augmentation of (Hammond, Hammond and Parkes), 1942, 32, 308

folding, physical effect of, on the soil (Keen and Cashen), 1932, 22, 126

gaseous metabolic products of, identification and measurement of the com. bustible gases that occur in (Lugg), $1938,28,688$

grass, consumed by, on pasturage of varying quality, determination of amounts of (Woodman, Evans and Eden), 1937, 27, 212

haemoglobin level of (Allcroft); 1941, 31, 320

induction of ovulation, superovulation and heat in (Hammond, Hammond and Parkes), 1942, 32, 308

maintenance requirement of the adult method of calculating (Hendricks and Titus), 1931, 21, 726

meat qualities in, with special reference to Scottish breeds and crosses (Pálsson), $1939,29,544 ; 1940,30,1$

Merino, effect of the administration of cystine, cystein, sulphur and of methionine on the growth of wool of, on a protein-poor ration (Marston), 1935, 25,113

Merino, relationship between nutrition and wool production of (Marston), $1935,25,103,113$

nutrition (Woodman, Evans and Eden), $1937,27,191,212$

osmotic pressure of the contents of the stomach compartments of, notes on (Davey), 1936, 26, 328

ovulation in the ewe (Anderson), 1938, 28,64

parasitic gastritis in, epidemiology of (Taylor), 1934, 24, 192

protein intake of, in relation to wool growth, variation in (Fraser and Roberts), 1933, 23, 97 
Sheep, relation between rates of growth and rickets in, on diets deficient in vitamin D (Duckworth, Godden and Thomson), 1943, 33, 190

respiratory exchange of fed, over periods of forty-eight hours, an apparatus and technique for measuring (Lines), 1938, 28,663

wool characters in 'half-bred' (Nichols), $1933,23,473$

see also Ewe, Lambs and Rams

Silage, composition of different kinds of (Smith and Comrie), 1938, 28, 203

electrode potentials in laboratory (Common and Bolton), 1942, 32, 338

grass, see Grass silage

low temperature, losses of dry matter and digestible nutrients in, with and without added molasses or mineral acids (Watson and Ferguson), 1937, 27, 67

made with molasses and A.I.V. fodder, value of, in the diet of the dairy cow, and effect on the quality of the milk (Watson and Ferguson), 1936, 26, 337

pit, digestibility and feeding value of (Watson), 1931, 21, 469

quality in, significance of the $p \mathrm{H}$ determination in the evaluation of (McLean), 1941, 31, 518

stack, digestibility and feeding value of (Watson), 1931, 21, 454

tower, digestibility and feeding value of (Watson), 1931, 21, 425

see also Ensilage

'Single value' soil properties (Coutts), $1935,25,523$

Six-day disease, bacterial syndrome arising from a diet which is conducive to (Mann), 1945, 35, 98

effect of diet on mortality with special reference to (Mann), 1945, 35, 95

mechanism of infection in, with special reference to intestinal putrefaction (Mann), 1945, 35, 108

Sodium, determination of, by precipitation as the triple salt sodium-uranylmagnesium acetate (Piper), 1932, 22, 676

hydroxide, effect of Beckmann's treatment by, on the digestibility and feeding value of barley straw for horses (Williamson), 1941, 31, 488

hydroxide solutions, solubility of soil phosphorus and other phosphorus compounds in (Williams), 1937, 27, 259

hypobromite, use of, for the oxidation of organic matter in the mechanical analysis of soils (Troell), 1931, 21, 476

nitrate, effect of, on the growth and nitrogen content of a lucerne and grass mixture (Thornton and Nicol), 1934, 24, 269
Sodium nitrate, reduction of nodule numbers and growth produced by the addition of, to lucerne in sand culture (Thornton and Nicol), 1936, 26, 173

Soil(s), acid, character of barley grown on soil made acid by sulphate of ammonia (Mann), 1937, 27, 108

acid, fifty years of wheat or barley cropping in (Mann and Barnes), 1940, 30, 345

acid, influence of fertilizers and lime on replaceable bases of, after fifty years of continuous cropping (Crowther and Basu), 1931, 21, 689

acidity, increase of, with depth in tropical soils (Doyne), 1935, 25, 192

acidity, influence of the plant upon seasonal changes in (Smith and Robertson), 1931, 21, 822

acidity, see also Soil, hydrogen-ion concentration

action of rolls on, account of methods employed in a study of (Culpin), 1937, 27,432

alkali, formation, evolution, reclamation, and the absorbed bases of (Kelley), $1934,24,72$

alkaline, fate of manganese sulphate in (Wain, Silk and Wills), 1943, 33, 18

ammonia and nitrate contents of, effects of summer green manures on (Mirchandani), 1931, 21, 458

ammonification, relations of Bacillus mycoides with (Tyagny-Ryadno), 1933, 23,335

analysis, selenium as a catalyst in the Kjeldahl method as applied to (Ashton), 1936, 26, 239

Azotobacter in Malayan, studies on (Altson), 1936, 26, 268

base exchange capacity, use of dihydrogen potassium phosphate in studying (Schofield), 1933, 23, 255

base exchange capacity of, contribution of clay and organic matter to (Williams), $1932,22,845$

base exchange equilibria in soil profiles (Mitchell), 1937, 27, 557

base status of Scottish (Mitchell), 1936, 26, 664; (Whelan), 1939, 29, 306

calcium cyanamide decomposition in (Crowther and Richardson), 1932, 22, 300

calcium status of, effect of nitrogenous fertilizers on (Lewis), 1938, 28, 197

carbon and nitrogen cycles in (Du Toit and Page), 1932, 22, 115; (Page), 1932, 22, 291; (Hobson and Page), 1932, 22, $297,497,516$

carbon in, accurate wet-combustion method for the determination of (Alper), 1938, 28, 187; 1942, 32, 389 
Soil(s) carbonate, determination of $\mathrm{ex}$ changeable bases in (Williams), 1932, 22, 838

clay, see Clay

clods and crumbs, determination of the size distribution of (Russell and Tamhane), 1940, 30, 210

clods, determination of the volume and air space of (Russell and Balcerek), $1944,34,123$

colloids, identification of, in minerals (Nagelschmidt), 1939, 29, 477

colour, note on a method for the preparation of permanent records (Whittles), $1931,21,189$

consolidation, effects of, on growth and development of rain-grown cotton (Heath), 1937, 27, 511

constants, changes produced in a soil by exposure to high temperatures (Coutts), $1932,22,200$

constants, moisture equivalent and some related quantities (Coutts), 1932,22, 203

constants, 'single value', significance of certain (Russell), 1933, 23, 261

constants, 'single value', significance of (Coutts), 1932, 22, 200, 203

constants, study of significance of certain (Coutts), 1935, 25, 523

cultivation, effect of, on crop yield (Russell and Keen), 1938, 28, 212

cultivation, studies in (Keen, Russell, Cashen, Heath, Mehta, Pereira and Mann), 1932, 22, 126; 1937, 27, 511; $1938,28,212,272 ; 1941,31,212,326$; $1942,32,330$

decomposing power of, in relation to soil types and vegetative covering in Glamorgan (Isaac), 1933, 23, 31

decomposition of calcium cyanamide in (Crowther and Richardson), 1932, 22, 300

decomposition of farmyard manure in, microbiology of (Jensen), 1931, 21, 38, $81 ; 1932,22,1$

decomposition of green manures in (Daji), 1934, 24, 15

decomposition of organic matter by hydrogen peroxide, influence of hydrogen-ion concentration on (Hosking), $1932,22,92$

dispersion studies on Gezira (Jewitt), $1941,31,466$

drainage and evaporation from fallow soil at Rothamsted (Penman and Schofield), 1941, 31, 74

drainage, scientific research in (Russell), $1934,24,544$

drift, genesis and development of two profiles of, in the North-east of Scotland (Stewart), 1933, 23, 73

effects of the Fowler 'Gyrotiller' on (Culpin), 1936, 26, 45
Soil (s), electrical capacity and conductivity of, measurements of (Cashen), 1932, 22, 145

electrical conductivity of aqueous soil suspensions, measurement of (Sen), $1932,22,212$

electrodialysis apparatus for the determination of replaceable bases in (Basu), 1931, 21, 484

evaporation and drainage from fallow soil at Rothamsted (Penman and Schofield), 1941, 31, 74

evaporation from fallow, laboratory experiments on (Penman), 1941, 31,454

examining, rapid methods of (Schofield and Blair), 1932, 22, 135; (Schofield), $1933,23,252,255$

exchangeable bases in carbonate soils, determination of (Williams), 1932, 22, 838

exchangeable bases of some East Anglian (Salgado), 1933, 23, 18

exchangeable hydrogen content of, com. parison of four methods for the estimation of the (Innes and Birch), 1945, 35, 236

exchangeable ions in, relationships between the sticky point and the nature of (Coutts), 1935, 25, 523

exhausted, influence of fallowing on the yield of wheat or barley on (Mann), $1943,33,207$

fallow, drainage and evaporation from, at Rothamsted (Penman and Schofield), 1941, 31, 74

fen, nutrition of the carrot grown in (Woodman and Paver), 1945, 35, 30

fertility, Azotobacter test of, applied to the classical fields at Rothamsted (Ziemięcka), 1932, 22, 797

fertility, biological aspects of (Nellson. Jones), 1941, 31, 379

fertility, electrical conductivity of aqueous soil suspensions as a measure of (Sen and Wright), 1931, 21, 1

fertility, relations of Bacillus mycoides with (Tyagny-Ryadno), 1933, 23, 335

fertility studies, measurement of electrical conductivity of aqueous soil suspension and its use in (Sen), 1932, 22, 212

formation in Southern Nigeria (Doyne and Watson), 1933, 23, 208

fractionation of the organic matter, including nitrogen, of certain soils and its relation to their quality (Ashworth), $1942,32,349$

freezing-point, measurement of $p \mathrm{~F}$ in soil by (Schofield and Costa), 1938, 28, 644 freezing-point method, indirect determination of the 'wilting coefficient' by, and the influence of the salts upon the $p \mathrm{~F}$ at that critical moisture content (Costa), 1938, 28, 654 
Soil(s), gas and vapour movements in (Penman), 1940, 30, 437, 570

grassland, nitrogen cycle in (Richardson), $1938,28,73$

grassland, studies on the microbiology of (Eggleton), 1934, 24, 416

gravel, response of the carrot to water supply and fertilizer on (Woodman and Johnson), 1944, 34, 82

beat of wetting measurements, application of, to soil research problems (Janert), 1934, 24, 136

heaviness, rapid method of examining (Schofield and Blair), 1932, 22, 135

heteroauxin in, estimation of traces of (Parker-Rhodes), 1940, 30, 654

humic matter of, origin of (Page), 1932, 22, 291

hydrogen-ion concentration, influence of, on the decomposition of soil organic matter by hydrogen peroxide (Hosking), 1932, 22, 92

hydrogen-ion concentration of, comparison of methods for determining (Best), 1931, 21, 337

hydrogen-ion concentration, see also Soil acidity

imbibitional water, on the measurement of (Russell and Gupta), 1934, 24, 314

improvement in the Sudan Gezira (Greene and Snow), 1939, 29, 1

in relation to marsh spot of pea seed (Furneaux and Glasscock), 1936, 26, 59

kaolinitic and lateritic, shrinkage behaviour of (Hardy), 1934, 24, 59

lateritic and kaolinitic, shrinkage behaviour of (Hardy), 1934, 24, 59

lime, effects of, on typical sorts from north-east Scotland (Mitchell), 1936, 26, 664; (Whelan), 1939, 29, 306

lime status of, use of $p$-nitrophenol for assessing (Schofield), 1933, 23, 252

limestone, effect of varied dressings (Nicholson), 1931, 21, 262

manganese in, availability of (Piper), $1931,21,762$

manganese of, readily soluble, and marsh spot of peas (Heintze), 1938, 28, 175

mechanical analysis of, an optical method for (Richardson), 1934, 24, 457

mechanical analysis of, improved technique in grading of coarse and fine sands during (Beater), 1937, 27, 123

mechanical analysis of, use of sodium hypobromite for the oxidation of organic matter in (Troell), 1931, 21, 476

mechanical analysis, sticky point, and moisture equivalent in some Australian, relationships between (Prescott and Poole), 1934, 24, 1

mechanical analysis, ultra-, of (Puri and Puri), 1941, 31, 171

IASI ii
Soil(s) microbiology of grassland soil, studies on (Eggleton), 1934, 24, 416

micro-organisms, a comparison of two agar media for counting (Jensen), 1931, 21, 832

mineral composition of South Ayrshire (Elder and McCall), 1936, 26, 1

mineralogy of the soil parent materials (Hart), 1941, 31, 438

minerals in the clay fractions of a black cotton soil and a red earth from Hyderabad, India (Nagelschmidt, Desai and Muir), 1940, 30, 639

moisture equivalent and some related quantities (Coutts), 1932, 22, 203

moisture equivalent, determination of, by the silt-suction method and the shifting of the $p F$ curve of stored soil samples (Costa and Alves), 1942, 32, 294

moisture equivalent, sticky point, and mechanical analysis in some Australian, relationships between (Prescott and Poole), 1934, 24, 1

moisture meter (Rogers), 1935, 25, 326

moisture, value of 'sticky point' determinations in field studies (West), 1931, 21, 799

mud, see Mud

nitrate and ammonia contents of, effecta of summer green manures on (Mir. chandani), 1931, 21, 458

nitrification, calcium cyanamide decomposition in soil and its effect on (Crowther and Richardson), 1932, 22, 300

nitrification in, microbiological aspects of (Mukerji), 1932, 22, 335

nitrification in Sudan Gezira (Jewitt), $1945,35,264$

nitrification, relations of Bacillus mycoides with (Tyagny-Ryadno), 1933, 23, 335

nitrogen and carbon cycles in (Du Toit and Page), 1932, 22, 115; (Page), 1932, 22, 291 ; (Hobson and Page), 1932, 22, $297,497,516$

nitrogen and organic carbon in, examination of methods for determining (Walkley), 1935, 25, 598

nitrogen cycle in grassland (Richardson), $1938,28,73$

organic carbon and nitrogen in, examina. tion of methods for determining (Walkley), 1935, 25, 598

organic constituents in north-east Scottish, proximate analysis of (Shewan), 1938, 28, 324

organic matter and clay, contribution of, to the base exchange capacity of (Williams), 1932, 22, 845

organic matter, effect of hydrogen peroxide on (McLean), 1931, 21, 251 
Soil(s) organic matter, fractionation of, including nitrogen, of certain soils and its relation to their quality (Ashworth), 1942 , 32, 349

organic matter, influence of hydrogen-ion concentration on the decomposition of, by hydrogen peroxide (Hosking), 1932, 22, 92

organic matter in, ignition at low temperatures of (Hosking), 1938, 28, 393

organic matter in, use of sodium hypo. bromite for the oxidation of, in the mechanical analysis of soils (Troell), 1931, 21, 476

organic matter, nature of, as shown by the attack of hydrogen peroxide (McLean), 1931, 21, 595

organic transformations in (Duthie), $1937,27,162$

organic nitrogen compounds of: 'humic' nitrogen (Hobson and Page), 1932, 22 , 497

organic nitrogen compounds of: 'nonhumic' nitrogen (Hobson and Page), $1932,22,516$

organic nitrogen of, extraction of, with alkali (Hobson and Page), 1932, 22, 297

oxidation-reduction potential measurements, and soil reaction, use of the glass electrode in (Heintze), 1934, 24, 28

peat, see Peat

permeability of saturated sands, soils and clays (Carman), 1939, 29, 262

$p F$ in, measurement of, by freezing. point (Schofield and Costa), 1938, 28, 644

phosphate, added, recovery of, from a soil of the acid igneous group (Williams and Stewart), 1943, 33, 179

phosphate fixation in Scottish (Williams and Stewart), 1943, 33, 179

phosphoric acid, total, in, new method for the determination of (Shrikhande), $1942,32,406$

phosphorus and other phosphorus com. pounds in sodium hydroxide solutions, solubility of (Williams), 1937, 27, 259

phosphorus, attempted fractionation of (Dean), 1938, 28, 234

phosphorusin, determination of (MoLean), $1936,26,331$

physical effect of sheep folding on (Keen and Cashen), 1932, 22, 126

plasticity of, effect of climatic variations on (Blair and Yates), 1932, 22, 639

profile ('Ilepa') in Southern Nigeria (Doyne and Watson), 1933, 23, 208

profile, some characteristic igneous rock soil profiles in British Guiana (Hardy and Follett-Smith), 1931, 21, 739
Soil(s) profiles, base exchange equilibria in (Mitchell), 1937, 27, 557

profiles of a drift soil in the north-east of Scotland, genesis and development of (Stewart), 1933, 23, 73

properties, 'single value' (Coutts), 1935 25,523

properties in relation to the occurrence of grass sickness in horses (Stewart). 1941, 31, 308

quality, fractionation of the organic matter, including nitrogen, of certain soils and its relation to (Ashworth), $1942,32,349$

reaction and oxidation-reduction poten. tial measurements, use of the glass electrode in (Heintze), 1934, 24, 28

reaction, calcium cyanamide decomposition in soil and its effect on (Crowther and Richardson), 1932, 22, 300

reaction, studies on (Basu), 1931, 21, 484; (Crowther and Basu), 1931, 21, 689

replaceable bases in, electrodialysis apparatus for the determination of (Basu), 1931, 21, 484

replaceable bases of a light acid soil, in. fluence of fertilizers and lime on, after fifty years of continuous cropping (Crowther and Basu), 1931, 21, 689

research problems, application of heat of wetting measurements to (Janert), $1934,24,136$

residual effects of the intensive use of sulphate of ammonia on pastures (Woodman and Evans), 1938, 28, 592

resistance, description of an instrument for the measurement of (Culpin), 1936, 26,22

salts, effect of irrigation on (Greene and Peto), 1934, 24, 42

sandy, red, of Palestine, pan (Nasas) and its origin in the (Menchikovsky), 1932, 22, 689

saturation capacity in some tropical soil types, determination of (Turner), 1932, 22, 72

sesquioxide components, identification and approximate estimation of, by adsorption of alizarin (Hardy), 1931, 21, 150

shrinkage behaviour of lateritic and kaolinitic (Hardy), 1934, 24, 59

size distribution of clods and crumbs, determination of (Russell and Tam. hane), 1940, 30, 210

sticky point and the nature of the exchangeable ions in, relationships between (Coutts), 1935, 25, 523

sticky point determinations, value of, in field studies of soil moisture (West), 1931, 21, 799 
Soil(s), sticky point, moisture equivalent, and mechanical analysis in some Australian, relationships between (Prescott and Poole), 1934, 24, 1

sticky point water of (Marchant), 1931, 21, 324

structure, cultivation implements and the crop, relation between (Culpin), 1936, $26,22,45 ; 1937,27,432$

structure, measurement of (Culpin), $1936,26,22$

studies in relation to geology in an area in north-east Scotland (Hart), 1941, 31, $438 ; 1942,32,373$

suspensions, aqueous, electrical con ductivity of, as a measure of soi fertility (Sen and Wright), 1931, 21, 1

suspensions, clay, theory of the coagulation of (Russell), 1932, 22, 165

suspensions, measurement of electrical conductivity of (Sen), 1932, 22, 212

teart, see Pastures

temperature, influence of, on germination interval of crops (Irwin), 1931, 21, 241

tilth, compressibility curves as a quanti. tative measure of (Blair), 1937, 27, 541; (Blair and Cashen), 1938, 28, 367

treatment, vitamin $B_{1}$ potency of wheat as influenced by (Harris), 1934, 24, 410

tropical, determination of saturation capacity in (Turner), 1932, 22, 72

tropical, increase of acidity with depth (Doyne), 1935, 25, 192

tropical, studies in (Hardy), 1931, 21, 150; 1934, 24, 59; (Hardy and FollettSmith), 1931, 21, 739; (Doyne), 1935 , 25, 192; (Duthie), 1937, 27, 162

types and vegetative covering in Glamorgan, rate of decay in relation to (Isaac), 1933, 23, 31

vapour and gas movements in (Penman), $1940,30,437,570$

water-logged, biochemistry of (Sreenivasan and Subrahmanyan), 1935, 25, 6 water-logged, carbon and nitrogen transformations (Sreenivasan and Subrah. manyan), 1935. 25. 6

water, measurement of the suction of, by Portland stone absorbers calibrated by a new method for determining vapour pressures near to saturation (Davidson and Schofield), 1942, 32, 413

'wilting coefficient', indirect determination of, by the freezing-point method, and the influence of the salts upon the $p F$ at that critical moisture content (Costa), 1938, 28. 654

'wilting coefficient' of, critical survey of investigations on (Costa), 1938, 28, 630

Spacing of sugar beet, experiments on (Garner and Sanders), 1939, 29, 48, 58; (Hey and Kemsley), 1939, 29, 69
Sperm production of adult rams in relation to frequency of semen collection (Chang), 1945, 35, 243

Spermatozoa in vitro, treatment of, with special reference to artificial insemina. tion (Chang), 1943, 33, 67

production of a pony stallion (Chang), $1943,33,67$

survival of, in the genital tract of the mare (Day), 1942, 32, 108

survival of stored, in the genital tract of the mare (Laing), 1943, 33, 64

survival time of, in the genital tract of the cow and its relation to fertility (Laing), $1945,35,72$

see also Semen

Spray(s)-lluids, fungicidal properties of certain (Martin and Salmon), 1931, 21, $638 ; 1932,22,595$; 1933, 23, 228; $1934,24,469$

fungicidal, see Fungicides

Stallion, pony, sperm production of (Chang), 1943, 33, 67

Starch equivalent, and seasonal variation in the composition and feeding value of concentrated swill (Woodman and Evans), 1944, 34, 110

Statistics, analysis of variance, note on the method of 'differential regression' in (Hendricks), 1937, 27, 188

analysis of variance, use of 'differential regression' in (Hendricks), 1935, 25, 258

basis of selection in animal husbandry (Olbrycht), 1943, 33, 28, 74

covariance, note on the analysis of (Bartlett), 1936, 26, 488

covariance, value of, in analysing field experimental data (Garner, Grantham and Sanders), 1934, 24, 250

covariance, value of, in dairy cow nutrition experiments, an examination of (Bartlett), 1935, 25, 238

differential regression, note on the method of, in analysis of variance (Hendricks), $1937,27,188$

differential regression, use of, in analysis of variance (Hendricks), 1935, 25, 258

empirical law describing heterogeneity in the yields of agricultural crops (Smith), $1938,28,1$

Fisher's $z$ test, validity of, when applied to an actual example of non-normal data (Eden and Yates), 1933, 23, 6

Latin square lay-out in animal experimentation, value of (Garner and Sanders), 1938, 28, 543

Latin squares, incomplete (Yates), 1936, 26, 301

Lattice squares (Yates), 1940, 30, 672

orthogonality and confounding in replicated experiments, principles of (Yates), 1933, 23, 108 
Statistics, polynomial coefficients fitted to growth rate data, study of (Donald), $1940,30,582$

statistical analysis of a laying experiment (Bolton and Hale), 1945, 35, 158

see also Experimental error, Field experiments, etc.

Sterility in dairy cattle, experiments on the use of chorionic gonadotrophin (pregnancy urine extract) for the treatment of (Bottomley, Folley and Watson), 1940, 30, 235

Stomach compartments of the sheep, notes on the osmotic pressure of the contents of (Davey), 1936, 26, 328

Storage of artificially dried grass (Wright), $1941,31,194$

of cereal feeding stuffs with incorporated non-protein nitrogen compounds (Snow, Smith and Wright), 1945, 35 65

Straw, barley, digestibility and feeding value of, for horses, effect of Beckmann's treatment by sodium hydroxide on (Williamson), 1941, 31, 488

pulp, digestibility of (Ferguson), 1943, 33, 174

Stripe diseases of barley and oats (Weston and Taylor), 1943, 33, 23

smut of rye (Taylor and Weston), 1945, 35,116

Sugar beet, chemical study of, during first growth year (Knowles, Watkin and Hendry), 1934, 24, 368

effect of inter-tillage on (Russell, Keen and Mann), 1942, 32, 330

feeding of, to laying pullets (Temperton and Dudley), 1943, 33, 204

germination and yield of, effects of seed treatments on (Garner and Sanders), $1932,22,551$

growing under continuous illumination, experiments on (Bell and Bauer), 1942, 32, 112; 1943, 33, 85

pulp, ammoniated, nutritive value of (Ferguson and Neave), 1943, 33, 95

pulp, dried molassed, digestibility of (Halnan), 1937, 27, 137

pulp, molassed, and cooked potatoes, use of, as supplemental foods (Woodman and Evans), 1943, 33, 155

spacing, experiments on (Garner and Sanders), 1939, 29, 48

Sulphate, copper, effect of continuous administration of, to dairy cows on teart pastures (Ferguson), 1943, 33, 116 manganese, fate of, in alkaline soils (Wain, Silk and Wills), 1943, 33, 18

of ammonia, see Ammonium sulphate

Sulphite, ammonium, see Ammonium sulphite

Sulphur content of fodder and excreta, estimation of (Marston), 1938, 28, 679
Sulphur, effect of administration of, on the growth of wool of a Merino ewe on a protein-poor ration (Marston), 1935, 25,113

hydrolysis of, fungicidal properties of the products of (Martin and Salmon), 1932, 22, 595

of pasture grass, studies of (Evans), 1931. 21,806

total, and sulphate sulphur in feeding stuffs, determination of (Woodman and Evans), 1933, 23, 459

Sulphuric acid and other compounds, eradication of weeds in cereal crops by (Blackman and Templeman), 1936, 26, 368

cotton-seed treatment with (Christidis), $1936,26,648$

Sunflower seed, digestibility and metabolizable energy of (Halnan), 1943, 33, 113

Superphosphate, storage and mixing with calcium cyanamide (Richardson), 1932, 22, 348

Surface area measurements of pigs, metabolism and (Deighton), 1937, 27, 317

of pigs and other animals, determination of (Deighton), 1932, 22, 418

Sussex ground oats, see Oats

Swayback disease of lambs, some observa. tions on (Shearer and McDougall), 1944, 34, 207

Swede bulbs, method of sampling by cores (Davey), 1932, 22, 767

Swill, chemical composition, digestibility and nutritive value of different types of (Woodman and Evans), 1942, 32, 85

concentrated, starch equivalent, and seasonal variation in the composition and feeding value of (Woodman and Evans), 1944, 34, 110

Tapioca flour, value of, in the nutrition of swine (Woodman, Menzies-Kitchin and Evans), 1931, 21, 526

Tar oils, see Oils

Tea, field experiments with, experimental errors of (Eden), 1931, 21, 547

leaf, seasonal and sampling variation in yield and mineral composition of (Eden), 1932, 22, 386

yield of, studies in (Eden), 1931, 21, 546; $1932,22,386$

Teart pasture, see Pasture

Temperature, effect of, on a mixed culture of two organisms in symbiotic relation (Richards), 1939, 29, 302

effects of, on percolation through drain gauges (Koshal), 1934, 24, 105

environmental, influence of, on the respiratory rhythm of dairy cattle in the tropics (Rhoad), 1936, 26, 36 
Temperature, incubation, influence of on the hatchability of eggs, post-natal growth and survival of turkeys (Romanoff), 1935, 25, 318

influence of, and available nitrogen supply on the growth of pasture in the spring (Blackman), 1936, 26, 620

low, grain pre-treatment, effect of, on the development, yield and grain of some varieties of wheat and barley (Bell) $1937,27,377$

low, growth of the root-nodule organisms and inoculated peas at (Vartiovara), $1937,27,626$

low, ignition at, of organic matter in soils (Hosking), 1938, 28, 393

soil, influence of, on germination interval of crops (Irwin), 1931, 21, 241

Thousand head kale, see Kale

Threshing machine, small scale, for cereal experiments (Simpson), 1931, 21,372

Tillage, see Cultivation

Time of application of sulphate of ammonia to wheat, effect of (Garner and Sanders), 1936, 26, 316

Time of cutting hay, and the losses entailed during haymaking (Watson, Ferguson and Horton), 1937, 27, 224

Tomato foliage, composition, effect of manurial treatment on (Owen), 1931, 21, 442

plants, analysis of (Owen), 1931, 21, 442

Toxic substances obtained from the wheat plant which inhibit the germination of the uredospores of various wheat rusts (Parker-Rhodes), 1939, 29, 399

Toxicity of pyrethrum dusts, loss of, on exposure to air and light (Tattersfield), $1932,22,396$

Tractors, pneumatic tyred, efficiency of, under farm conditions (Russell, Hine and Keen), 1942, 32,

Turkeys, influence of incubation temperature on the hatchability of eggs, post-natal growth and survival of (Romanoff), 1935, 25, 318

Turnip, effect of time of application of inorganic nitrogen on (Woodman and Paver), 1944, 34, 49

Urea and guanidine and their nitrates and phosphates, fertilizer value of (Lewis), 1936, 26, 509

for pigs, war-time rations (Braude and Foot), 1942, 32, 70

Uredospores of various wheat rusts, certain toxic substances obtained from the wheat plant which inhibit the germination of (Parker-Rhodes), 1939, 29, 399

Urocystis occulta (Wallr.), see Stripe smut
Vapour(s) and gas movements in the soil (Penman), 1940, 30, 437, 570

diffusion of, through porous solids (Penman), 1940, 30, 437

Variety trials involving a large number of varieties, new method of arranging (Yates), 1936, 26, 424

with cotton, design of plots for (MacDonald, Fielding and Ruston), 1939, 29,35

Vegetable(s), nutrition of, studies in (Woodman), 1939, 29, 229

nutrition of, see also Specific crops oils, see Oils

Vegetation and soil types in Glamorgan, rate of decay in relation to (Isaac), $1933,23,31$

Vernalization, experiments on (Bell), $1936,26,155$

preliminary experiments on (Bell), 1935, 25, 245

Vicia faba L., see Bean, broad

Vitamin A content of the colostrum of dairy cows (Stewart and McCallum), $1938,28,428$

metabolism, effect of diet on (Mann), $1945,35,101$

requirement of swine (Dunlop), 1935, 25, 217

Vitamin $B_{1}$ potency of wheat as influenced by soil treatment (Harris), 1934, 24,410

Vitamin $D$, calcium and phosphorus requirement of swine (Dunlop), 1935, 25,22

relation between rates of growth and rickets in sheep on diets deficient in (Duckworth, Godden and Thomson), $1943,33,190$

Vitamin $D_{3}$ requirements of pullet chicks (Wright), 1941, 31, 161

vitamins, fat-soluble, requirements of cattle and pigs during growth (Isaachsen), 1932, 22, 460

Wastage, length of productive life, replacement and depreciation of dairy cows (Pettit), 1940, 30, 485

Water consumption of suckling sows (Garner and Sanders), 1937, 27, 638

imbibitional, on the measurement of (Russell and Gupta), 1934, 24, 314

sticky point, of soils (Marchant), 1931, 21, 324

transport of, through heavy clay soils (Childs), 1936, 26, 114, 527; (Nicholson and Childs), 1936, 26, 128

see also Rainfall

Weaning weight of pigs and litter sampling with reference to litter size (Smith and Donald), 1937, 27, 485

Weeds, annual, and cereal crops, nature of the competition between (Blackman and Templeman), 1938, 28, 247 
Weeds, eradication of, in cereal crops by sulphuric acid and other compounds (Blackman and Templeman), 1936, 26, 368

Whalo-meat as a constituent of chick diets, observations on (Halnan), 1942, 32, 179

Wheat after potatoes, preparation of seed bed for (Garner and Sanders), 1936, 26, 415 analytical yield investigations on New Zealand (Frankel), 1935, 25, 466; $1939,29,249$

baking quality of English, influence of manurial treatment on (Fisher and Jones), 1931, 21, 574

blending varieties of (Frankel), 1939, 29, 249

breeding for baking quality, critical survey of (Frankel), 1940, 30,98

cropping in acid soils, fifty years of (Mann and Barnes), 1940, 30, 345

differentiation of grain samples of closely related varieties of, by means of a simple mechanical test for grain quality (Frankel), 1935, 25, 461

effect of applying a nitrogenous fertilizer to, at different stages of growth (Watson), 1936, 26, 391

effect of low-temperature grain pretreatment on the development, yield and grain of some varieties of (Bell), $1937,27,377$

effect of time of application of sulphate of ammonia to (Garner and Sanders), $1936,26,316$

field experiments on the effect of applying a nitrogenous fertilizer to, at different stages of growth (Watson), 1939, 29, 379

growth, amounts and distribution of some phosphorus and nitrogen compounds in wheat during (Knowles and Watkin), 1932, 22, 755

growth, assimilation and translocation of plant nutrients during (Knowles and Watkin), 1931, 21, 612

growth distribution of some reserve substances in, at successive growth stages (Malhotra), 1932, 22, 485

hybrid vigour in (Engledow and Pal), $1934,24,390$

offals, bran, effect of war-time changes in milling practice on the composition and nutritive value of fine and coarse (Halnan), 1944, 34, 133

offals, bran, stored, respiration rate and loss of dry matter from (Snow and Wright), $1945,35,126$

offals, digestibility of (Halnan), 1937, 27, 126

offals, influence of war-time milling control on the composition, digestibility and nutritive value of (Woodman and Evans), 1944, 34, 35
Wheat plant, toxic substances obtained from, which inhibit the germination of the uredospores of various wheat rusts (Parker-Rhodes), 1939, 29, 399

population studies with (Hudson), 1939, 29,$76 ; 1941,31,116, .138$

rusts, see Rusts

sampling observations on, of the cropweather scheme, an examination of (Barnard), 1936, 26, 456

sampling technique with, study in (Kalamkar), 1932, 22, 783

seed rates in nursery trials and field plots (Hudson), 1941, 31, 138

spring- and autumn-dressed, effect of rainfall on ('Alumnus'), 1932, 22, 101 spring cultivation of autumn-sown (Garner and Sanders), 1937, 27, 447

vitamin $B_{1}$ potency of, as influenced by soil treatment (Harris), 1934, 24, 410

winter, effects of summer green manures on the ammonia and nitrate contents of soils cropped for (Mirchandani), 1931, 21, 458

winter, winter leaching and the manurial value of green manures and crop residues for (Crowther and Mirchandani), 1931, 21, 493

vield of, effect of time and rate of application of nitrogen fertilizers on (Lewis, Procter and Trevains), 1938, 28, 618

yield of, on very exhausted land, in. fluence of fallowing on (Mann), 1943, 33, 207

White maize meal, see Maize

'Wilting coefficient', indirect determination of, by the freezing-point method, and the influence of the salts upon the $p F$ at that critical moisture content (Costa), 1938, 28, 654

of soils, critical survey of investigations on (Costa), 1938, 28, 630

Winnowing machine, small scale, for cereal experiments (Simpson), 1931, 21, 372

Winter hardiness in oats, determination of (Mather and Andersson), 1934, 24,627

of clover, studies on (Virtanen and Nurmia), 1936, 26, 288

Wool characters in 'half-bred' sheep (Nichols), 1933, 23, 473

development of the characters of the fleece during growth in the different regions of the body (Thomasset), 1938, 28,523

growth of, effect of the administration of cystine, cystein, sulphur and of methionine on, of a Merino ewe on a protein-poor ration (Marston), 1935, 25,113

growth, variation in the protein intake of sheep in relation to (Fraser and Roberts), 1933, 23, 97 
Wool production of Merino sheep, relationship between nutrition and (Marston), $1935,25,103,113$

Xanthophyll metabolism, effect of diet on (Mann), 1945, 35, 101

Yeast, fodder, see Fodder

Yield(s) characters of selected oat varieties in relation to cereal breeding technique (Stephens), 1942, 32, 217

crop, effect of cultivation on (Russell and Keen), 1938, 28, 212

in cereal experiments, estimation of the efficiency of sampling, with special reference to sampling for (Yates and Zacopanay), 1935, 25, 545

in cereals, investigations on (Engledow and $\mathrm{Pal}), 1934,24,390$

in cereals, investigations on. Victoria (Forster and Vasey), 1931, 21, 391

of agricultural crops, empirical law describing heterogeneity in (Smith), $1938,28,1$

of cereal experiments, estimation of, by sampling for the ratio of grain to total produce (Cochran), 1940, 30 , 262

of cereals in relation to manurial treatment, influence of rainfall on (Cochran), $1935,25,510$

of certain tropical fodders (Paterson), $1935,25,369$

of cotton in hand-planted cotton trials, effects of seed rate and time of thinning on development and (MacDonald, Fielding and Ruston), 1939, 29, 418

of crops grown in rotation, effects of fertilizers and rainfall on (Cowie), 1945, 35, 197

of field beans, effect of borax dressings on growth and (Owen, Snow and Thom), $1945,35,119$

of grassland herbage, effect of nitrogen on (Watson, Procter and Ferguson), 1932, 22, 257

of hay, effect of manures and lime on botanical composition and (Jacques), $1933,23,146$

of lucerne (Woodman, Evans and Norman), 1933, 23, 419

of lucerne, influence of systematic cutting at three different stages of growth on (Woodman, Evans and Norman), 1934, 24,283
Yield(s) of mangolds, influence of rainfall on (Kalamkar), 1933, 23, 571

of mangolds, statistical examination of (Kalamkar), 1933, 23, 161

of meadow hay from certain plots at Cockle Park (Elliott and Thomas), 1934, 24, 379

of pasture, influence of a single heavy dressing of sulphate of ammonia compared with periodic small dressings (Woodman, Evans and Oosthuizen), $1938,28,598$

of pasture grass from the Tree Field Plots at Cockle Park (Thomas and Elliott), 1932, 22, 736

of pasture herbage, influence of intensity of grazing on yield, composition and nutritive value (Woodman, Norman and French), 1931, 21, 267; (Woodman and Norman), 1932, 22, 852

of pasture herbage, influence of successive applications of nitrogen on (Shutt and Hamilton), 1934, 24, 341

of potatoes, effect of inter-row tillage on (Pereira), 1941, 31, 212

of some varieties of wheat and barley, effect of low-temperature grain pretreatment on (Bell), 1937, 27, 377

of sugar beet, effects of seed treatments on (Garner and Sanders), 1932, 22, 551

of tea, studies in (Eden), 1931, 21, 547; $1932,22,386$

of tropical fodder grasses, influence of time of cutting on (Paterson), 1933, 23, 615

of wheat, analytical investigations on New Zealand (Frankel), 1935, 25, 466 of wheat, effect of time and rate of application of nitrogen fertilizers on (Lewis, Procter and Trevains), 1938, 28, 618

of wheat or barley on very exhausted land, influence of fallowing on (Mann), 1943, 33, 207

tests on sand cultures of May King lettuce, phosphate deficiency and (Woodman), $1939,29,229$

trials with cotton, inter-varietal competition in (Christidis), 1935, 25, 231

Yorkshire fog seed, commercial, data on, with a note on inorganic constituents (Rutledge and Common), 1945, 35, 123

Zebu, comparative digestive powers of (French), 1940, 30, 503

oestrus in, periodicity and duration of (Anderson), 1944, 34, 57 